Dear Author,

Please, note that changes made to the HTML content will be added to the article before publication, but are not reflected in this PDF.

Note also that this file should not be used for submitting corrections. 


\section{Holocene climate change in Arctic Canada and Greenland}

Q11 Jason P. Briner ${ }^{\text {a, * }}$, Nicholas P. McKay ${ }^{\text {b }}$, Yarrow Axford ${ }^{c}$, Ole Bennike ${ }^{d}$, Raymond S. Bradley ${ }^{\mathrm{e}}$, Anne de Vernal ${ }^{\mathrm{f}}$, David Fisher ${ }^{\mathrm{g}}$, Pierre Francus ${ }^{\mathrm{h}, \mathrm{i}}$, Bianca Fréchette ${ }^{\mathrm{f}}$, Konrad Gajewski ${ }^{\mathrm{j}}$, Anne Jennings ${ }^{k}$, Darrell S. Kaufman ${ }^{\mathrm{b}}$, Q1,2 Gifford Miller ${ }^{1}$, Cody Rouston ${ }^{\mathrm{b}}$, Bernd Wagner ${ }^{\mathrm{m}}$

a Department of Geology, University at Buffalo, Buffalo, NY, USA

b School of Earth Sciences \& Environmental Sustainability, Northern Arizona University, Flagstaff, AZ, USA

${ }^{c}$ Dept of Earth and Planetary Sciences, Northwestern University, Evanston, IL, 60208, USA

d Geological Survey of Denmark and Greenland, Copenhagen, Denmark

e Department of Geosciences, University of Massachusetts, Amherst, MA, 01003, USA

${ }^{\mathrm{f}}$ Centre de recherche en géochimie et géodynamique (Geotop), Université du Québec à Montréal, Montréal, QC, Canada

${ }^{g}$ Department of Geology, University of Ottawa, Ottawa, ON, K1N6N5, Canada

Q3 h Centre Eau Terre Environnement, Institut national de la recherche scientifique, Québec, Qc G1K 9A9, Canada

i GEOTOP Research Center, Montréal, Qc H3C 3P8, Canada

j Department of Geography, Environment and Geomatics, University of Ottawa, Ottawa, ON, K1N6N5, Canada

${ }^{\mathrm{k}}$ Institute of Arctic and Alpine Research, University of Colorado, Boulder, USA

${ }^{1}$ Department of Geological Sciences and Institute of Arctic and Alpine Research, University of Colorado, Boulder, USA

${ }^{\mathrm{m}}$ Institute of Geology and Mineralogy, University of Cologne, Köln, Germany

\section{A R T I C L E I N F O}

\section{Article history:}

Received 27 April 2015

Received in revised form

10 December 2015

Accepted 8 February 2016

Available online $\mathrm{xxx}$

\section{Keywords:}

Greenland

Holocene

Arctic Canada

Holocene thermal maximum

Neoglacial

\begin{abstract}
A B S T R A C T
This synthesis paper summarizes published proxy climate evidence showing the spatial and temporal pattern of climate change through the Holocene in Arctic Canada and Greenland. Our synthesis includes 47 records from a recently published database of highly resolved Holocene paleoclimate time series from the Arctic (Sundqvist et al., 2014). We analyze the temperature histories represented by the database and compare them with paleoclimate and environmental information from 54 additional published records, mostly from datasets that did not fit the selection criteria for the Arctic Holocene database. Combined, we review evidence from a variety of proxy archives including glaciers (ice cores and glacial geomorphology), lake sediments, peat sequences, and coastal and deep-marine sediments. The temperature-sensitive records indicate more consistent and earlier Holocene warmth in the north and east, and a more diffuse and later Holocene thermal maximum in the south and west. Principal components analysis reveals two dominant Holocene trends, one with early Holocene warmth followed by cooling in the middle Holocene, the other with a broader period of warmth in the middle Holocene followed by cooling in the late Holocene. The temperature decrease from the warmest to the coolest portions of the Holocene is $3.0 \pm 1.0^{\circ} \mathrm{C}$ on average $(\mathrm{n}=11$ sites $)$. The Greenland Ice Sheet retracted to its minimum extent between 5 and $3 \mathrm{ka}$, consistent with many sites from around Greenland depicting a switch from warm to cool conditions around that time. The spatial pattern of temperature change through the Holocene was likely driven by the decrease in northern latitude summer insolation through the Holocene, the varied influence of waning ice sheets in the early Holocene, and the variable influx of Atlantic Water into the study region.
\end{abstract}

(C) 2016 Published by Elsevier Ltd.

\footnotetext{
* Corresponding author.

E-mail address: jbriner@buffalo.edu (J.P. Briner).
}

\section{Introduction}

We can improve our understanding of the sensitivity of Arctic systems to climate change by assessing past climate change through time and space (e.g., Kaufman et al., 2004). For example, whether the Arctic cooled from the early to late Holocene in a

http://dx.doi.org/10.1016/j.quascirev.2016.02.010

0277-3791/@ 2016 Published by Elsevier Ltd. 
gradual or stepwise manner in response to gradual insolation change provides insights into internal thresholds intrinsic to the Arctic climate system. The role of past sea-ice variability and shifting ocean currents in modulating spatial patterns of temperature and precipitation in the past may help predict future spatial patterns of precipitation and temperature. Finally, the suggestion that climate change during the early Holocene was regionally affected by waning ice sheets and their influence on adjacent seas may provide clues about future patterns of climate change in heavily glaciated regions (e.g., Kaufman et al., 2004; Kaplan and Wolfe, 2006; Renssen et al., 2009). Addressing these features of the Holocene climate record may reveal the relative importance of key forcing mechanisms of climate change, internal thresholds and feedbacks within the climate system, and benchmarks for climate models.

The Greenland Ice Sheet (GrIS) and heavily glaciated eastern Canadian Arctic comprise the majority of glacier ice in the Northern Hemisphere (Gardner et al., 2013). Thus, northeastern North America is a particularly suitable area for scrutinizing paleoclimate and glacial-geologic records that reveal the sensitivity of glaciers and ice sheets to climate change. The region flanks key centers of Atlantic Meridional Overturning Circulation, and is heavily influenced by Arctic and Atlantic surface ocean currents.

Previously published syntheses of Arctic climate change have produced a temperature reconstruction of the past 2000 years (Kaufman et al., 2009), focused on the timing of the Holocene thermal maximum (Kaufman et al., 2004), used a single proxy type (Gajewski, 2015) or presented regional views (e.g., Bradley, 1990; Gajewski and Atkinson, 2003; Gajewski et al., 2009). There have been syntheses of Holocene climate and glaciation of Baffin Island (Miller et al., 2005; Briner et al., 2009a) and on the long-term history of the GrIS (Funder et al., 2011). However, there has been no recent multi-proxy synthesis of Holocene climate change in the Arctic Canada/Greenland sector of the Arctic, including both terrestrial and marine records, despite the increasing number of Holocene climate reconstructions from land, ocean and ice.

Here we review published Holocene paleorecords from the Canadian Arctic, Greenland and adjacent seas. We combine an analysis of the temperature-sensitive records within the recently published Arctic Holocene database (Sundqvist et al., 2014) with additional evidence from a broader suite of published studies. Our primary goal is to determine temperature trends during the Holocene, and the spatial pattern of temperature change throughout the region. A secondary goal is to compare records of paleoclimate changes with the size of the GrIS through the Holocene. In addressing these goals, we focus primarily on climate change trends at the millennial timescale.

\section{Regional setting and climatic influences}

This synthesis includes records that extend from the eastern continental shelf of Greenland in the east to $\sim 120^{\circ} \mathrm{W}$ longitude in the central Canadian Arctic in the west (Fig. 1) and from $\sim 58^{\circ} \mathrm{N}$ to sites on northernmost Greenland. The region includes the High Arctic islands and sounds heavily influenced by influx of cold marine surface waters from the Arctic Ocean, such as the East Greenland Current flowing along eastern Greenland. Baffin Bay, the basin between the Canadian Arctic and West Greenland, receives the relatively warm West Greenland Current from the south, and relatively cold East Baffin Current from the north (Fig. 1). The climate on either side of Baffin Bay reflects this oceanographic pattern in both temperature and precipitation amounts; precipitation is typically much greater around Greenland than in the Canadian Arctic.

The temperature gradients in the Canadian Arctic are not zonal, rather, lowest summer temperatures are located in the northwest, and the eastern Arctic Islands such as and Devon and Ellesmere Islands are warmer than islands to the west at the same latitudes (Edlund and Alt, 1989; Atkinson and Gajewski, 2002). Greenland also has large climate gradients, from the relatively warm and moist south and west, to the cold and arid climates of the north and east, where shores are locked in sea ice for much of the year. Another key temperature gradient in Greenland is from offshore to inland, where a significant difference is found across a short distance. Although there is also a coastal effect in the Canadian Arctic (Atkinson and Gajewski, 2002), it is smaller than that found in Greenland. Southwest Greenland, southern Baffin Island and Labrador encircle the Labrador Sea, which is heavily influenced by Atlantic water advection and the western extent of the North Atlantic Subpolar Gyre. Patterns in ocean circulation and configuration of the subpolar gyre through the Holocene dictate climatic conditions not only in areas bordering the Labrador Sea, but also across Baffin Bay, particularly in the east, due to its climate being strongly modulated by the West Greenland Current, fed by Irminger Current water as the northern limb of the gyre.

Through the Holocene, the major driver of climate change is insolation; however, this is heavily modulated in the early Holocene by waning ice sheets and associated meltwater release, sometimes periodic, into adjacent seas (Fig. 2). The presence of ice sheets well into the Holocene is an important consideration for a synthesis of Holocene climate change. For example, because ice still covered many portions of the Canadian Arctic until the middle Holocene (Fig. 3), lacustrine records from those regions clearly cannot be used to assess whether the thermal maximum took place in the early Holocene. An additional factor that drives temperature and precipitation changes through the Holocene is ocean circulation changes in the Labrador Sea and Baffin Bay, modulated by the strength of western branch of Atlantic Meridional Overturning Circulation and by the connection with the Arctic Ocean via opening of the Canadian Arctic channels. Finally, the extent and seasonal duration of sea ice may have played a key role in moisture supply on the northern borders of the focus area.

\section{Arctic Holocene database}

Sundqvist et al. (2014) compiled a database of 167 previously published Holocene proxy climate records from the Arctic. Records included in the database (1) are from northern high latitude $\left(>58^{\circ} \mathrm{N}\right),(2)$ have a demonstrated relation with a climate variable (although not necessarily calibrated), (3) are continuous time series that include at a minimum the entire 6 to $2 \mathrm{ka}$ time period, (4) are resolved at sub-millennial scale $(<400 \pm 200 \mathrm{yr}),(5)$ are supported by at least one age per 3000 years, and (6) are published in peerreviewed literature. Here, we extract all records from the current version (v.2; http://www.ncdc.noaa.gov/paleo/study/15444) of the Arctic Holocene database from the Canadian Arctic and Greenland region and the mainland Canada region $(n=47$; Table 1$)$. Of these, 33 are interpreted to represent either mean annual and/or summer temperature. The remaining are interpreted to represent sea-ice conditions or some measure of effective moisture (Table 1$)$. The records are from lacustrine $(n=26)$, marine $(n=10)$, ice $(n=9)$ and peat $(n=2)$ archives, and include proxy data from pollen, chironomids, isotopes of precipitation, ice core melt layers, biomarkers (e.g., alkenones, $\mathrm{IP}_{25}$ ), sediment organic matter/mineral matter proxies, and marine dinocysts.

We depict the 33 temperature time series as a heat map that illustrates temperature change in standard deviation units in 200year bins. The 200-year bins are normalized over the period of common overlap (i.e., the time steps when all records have values), and are used to determine a mean and standard deviation for each 


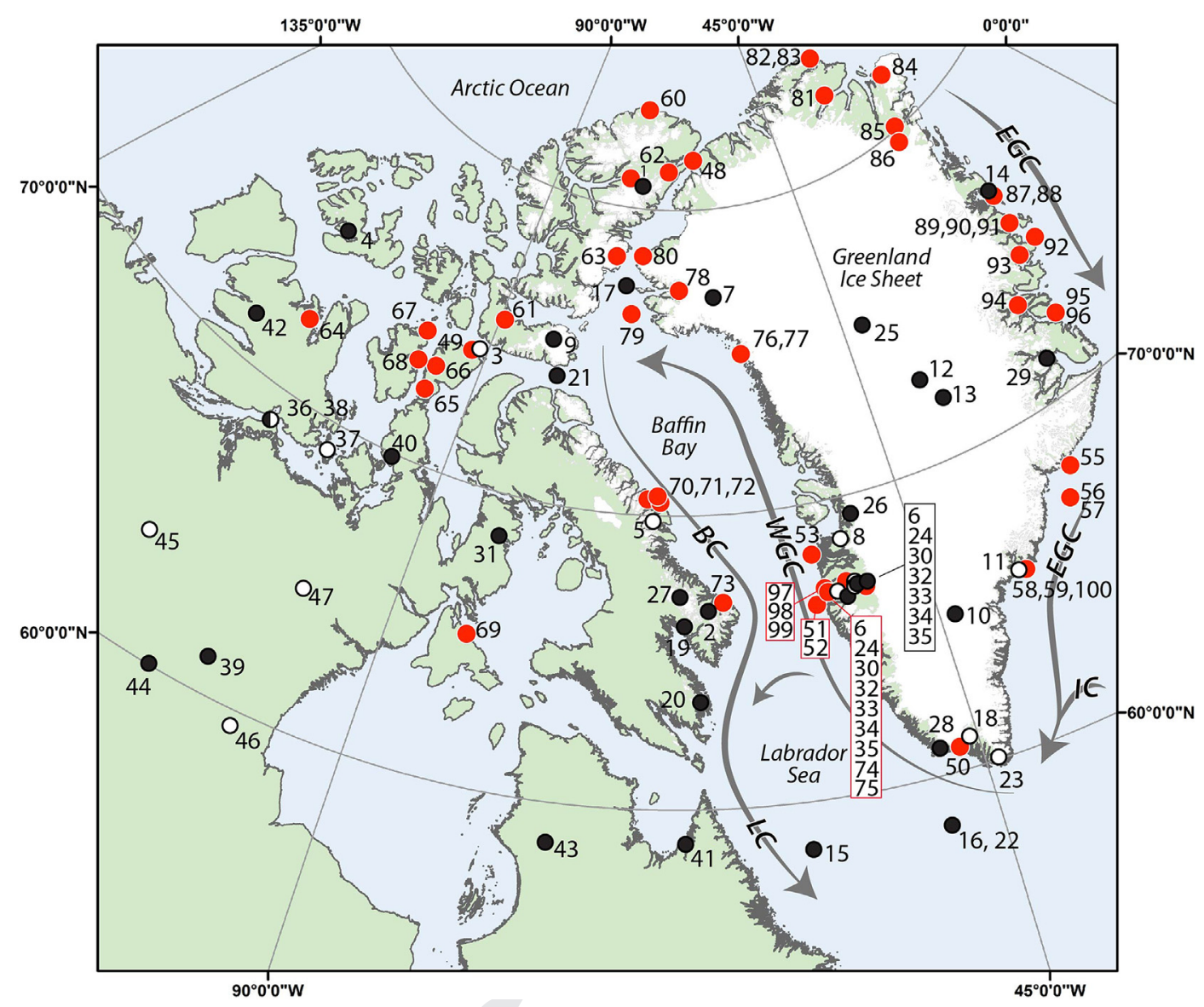

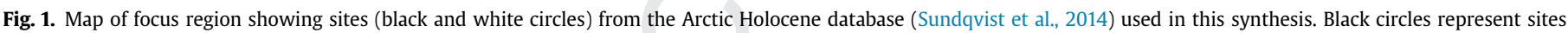

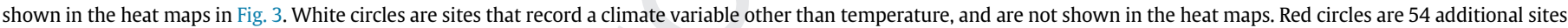

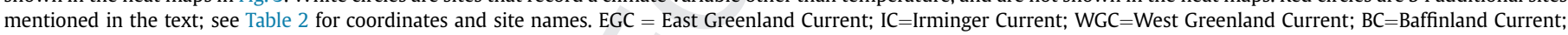
$\mathrm{LC}=$ Labrador Current. (For interpretation of the references to color in this figure legend, the reader is referred to the web version of this article.)

record, which is then used to standardize the full record. We also perform probabilistic principal components analysis (pPCA; Tipping and Bishop, 1999) on the 200-year averages of the 33 records between 8 and 0 ka. pPCA uses an expectation maximization algorithm to iteratively infill missing data (Tipping and Bishop, 1999). These analyses were performed in R version 2.15 .2 using the pcaMethods package.

The predominant trend throughout the region is cooling from the early or middle Holocene through the late Holocene; however, the detailed structure of Holocene temperature changes varies spatially (Fig. 4). Some records show a very warm early Holocene followed by net cooling since $8 \mathrm{ka}$, whereas others are characterized by maximum warmth sometime during the middle Holocene (Fig. 4). Principal components analysis reveals major features of regional climate variation since $8 \mathrm{ka}$ (Fig. 5). The records that load heavily on PC1 (explaining 34\% of the variance) are those with strong contrasts between early/middle and late Holocene climate. These are sites with clear patterns of maximum warmth over multiple millennia in either the early to middle Holocene $(7-5 \mathrm{ka}$; positive loadings) or the late Holocene $(4-0 \mathrm{ka}$; the less common negative loadings). PC2 (explaining $16 \%$ of the variance) reflects sites with high temperatures later in the Holocene.

An explicit goal of this paper is to investigate these patterns further using a broader suite of available paleorecords. For example, we are intrigued by the later and more subdued thermal maximum recorded at sites neighboring the Labrador Sea and mainland Canada. Further, we wish to assess modulation of Holocene climate by ice sheet meltwater and ocean circulation changes, and thus investigate multiple proxies spanning climate gradients of our study region.

\section{Quantitative and qualitative reconstructions of Holocene climate change}

Here we integrate the proxy climate records in the Arctic Holocene database with additional paleorecords that have been published from the region. Some of the additional evidence was published following the completion of the Sundqvist et al. (2014) database or was previously overlooked and will be included in a subsequent version of the database. These records are flagged in Table 2. Some of the additional evidence is from archive types that do not fit a database of continuous time series (e.g., glacial landforms, occurrence of extralimital taxa, assemblage data that are not reduced to a single climate-related valuable), or records that did not meet the selection criteria (due to insufficient duration, temporal resolution or age control) for inclusion in the Arctic Holocene database. Nonetheless, our goal is to review evidence for Holocene climate change represented by the records in the database alongside a more complete suite of published paleorecords from the region to better assess the extent to which a wider variety of evidence converges on a coherent pattern. Records that were not included in the Arctic Holocene database nonetheless contain information useful for addressing a variety of key questions about Holocene climate and environmental changes. All ages are reported 


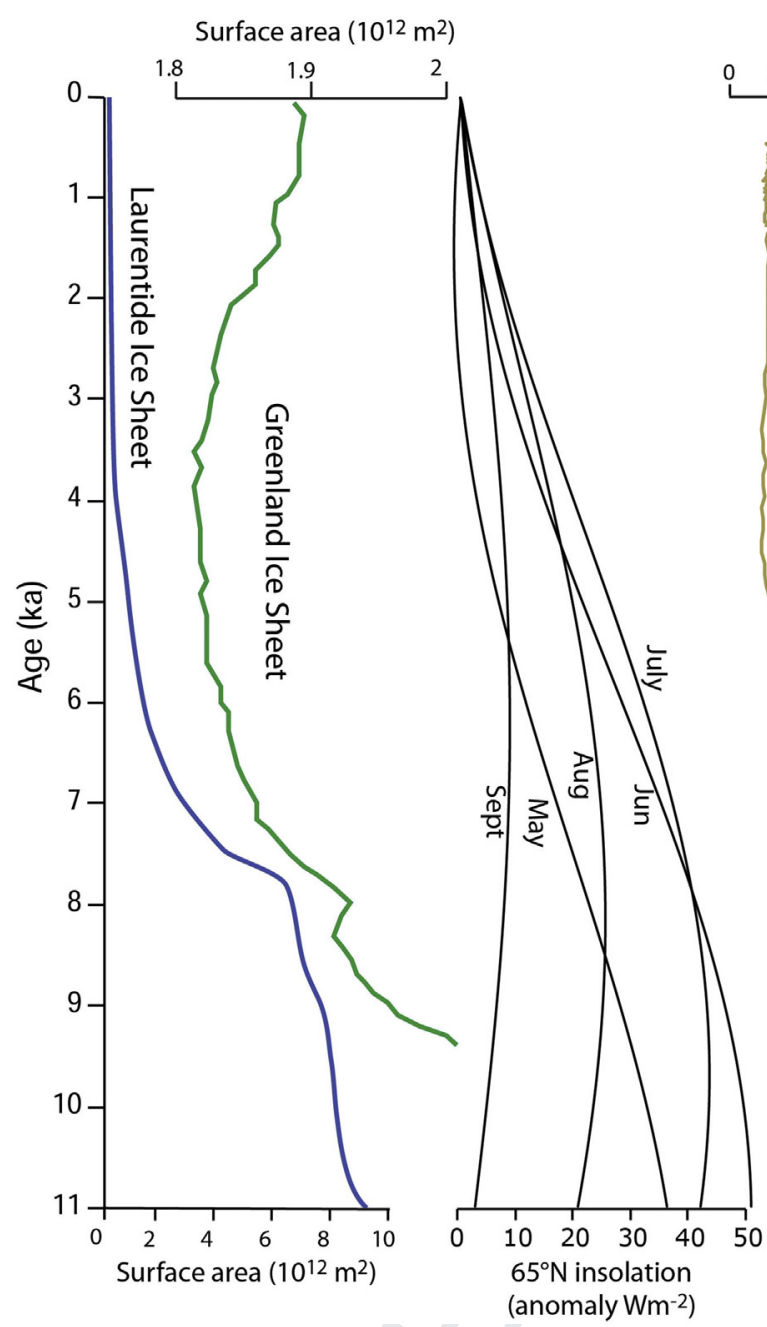

Carbonate (\%)

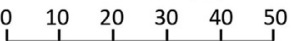

9 10 11 12 13 14 15 16 17 18 19 20 21 22 23 24 25 26 28 29 30 31 32 33 35 35 36 38 38 39 40 41 42 43 44 45 46 47 48 48 49 50 51 52 53 54 54 55 56 57 58 58 59 60 61 62 63 64 64
65

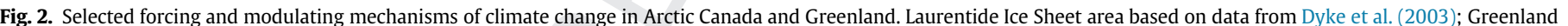

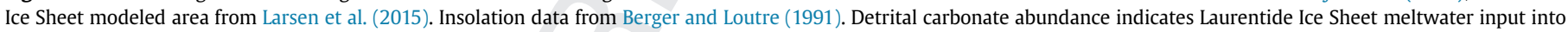

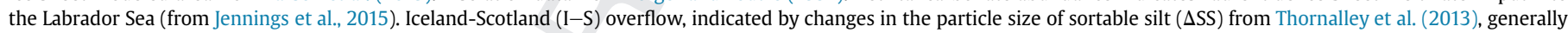
records the strength of Atlantic Meridional Overturning Circulation and the strength/size of the subpolar gyre.

in calendar kilo years BP (ka) unless otherwise specified. Records from the Arctic Holocene database are listed in Table 1, all additional records discussed are in Table 2; all site locations are shown in Fig. 1.

\subsection{Ice cores}

Many long ice cores have been collected from Greenland and the eastern Canada Arctic. The often-used $\delta^{18} \mathrm{O}$ is not a straightforward proxy for temperature over the Holocene because it is affected by elevation changes of the ice core site, moisture source, seasonal distribution of snowfall and noise (Fisher et al., 1996; MassonDelmotte et al., 2005). In addition to water isotopes, paleotemperature reconstructions have been modeled from presentday borehole temperatures, isotopic gradients in trapped air, and from melt layers.

Despite its complications in terms of climate interpretation, $\delta^{18} \mathrm{O}$ has been measured on ice cores that span the Holocene from Greenland, Baffin, Devon and Ellesmere islands in the Canadian Arctic, and are included in the Arctic Holocene database (Fig. 6). Vinther et al. (2009) proposed that the $\delta^{18} \mathrm{O}$ values from the Renland and Agassiz ice caps are more straight forward to interpret than those from the GrIS because their surface elevation changes throughout the Holocene can be estimated by data-constrained model calculations, and the influence of height changes at their ice core sites can be corrected. Furthermore, Vinther et al. (2009) argued that elevation-corrected $\delta^{18} \mathrm{O}$ records from across Greenland should be the same, and derived a Greenland-wide temperature record by averaging the elevation-corrected $\delta^{18} \mathrm{O}$ records from Renland and Agassiz (Fig. 7). The temperature record, which integrates all seasons, shows rapid warming from the onset of the Holocene until $\sim 9.5 \mathrm{ka}$, relatively uniform temperature at the millennial scale until $\sim 7 \mathrm{ka}$, followed by $\sim 3.5{ }^{\circ} \mathrm{C}$ temperature decline to the Little Ice Age, followed by $\sim 1.5^{\circ} \mathrm{C}$ warming to today (Fig. 7). The record also shows centennial-scale variability on the order of $1-2{ }^{\circ} \mathrm{C}$, and $\mathrm{a} \sim 3{ }^{\circ} \mathrm{C}$ temperature oscillation during the 8.2 ka event. Despite the fact that this record is corrected for elevation changes at Agassiz and Renland, and is calibrated to borehole temperatures, there are other processes that can influence isotope ratios of precipitation. However, Vinther et al. (2009) point out that the combined Agassiz/Renland $\delta^{18} \mathrm{O}$ record should be a reasonable temperature reconstruction for the Holocene that is at least not influenced by elevation history. More recent and ongoing dataconstrained uplift and ice sheet modeling work suggests that the 


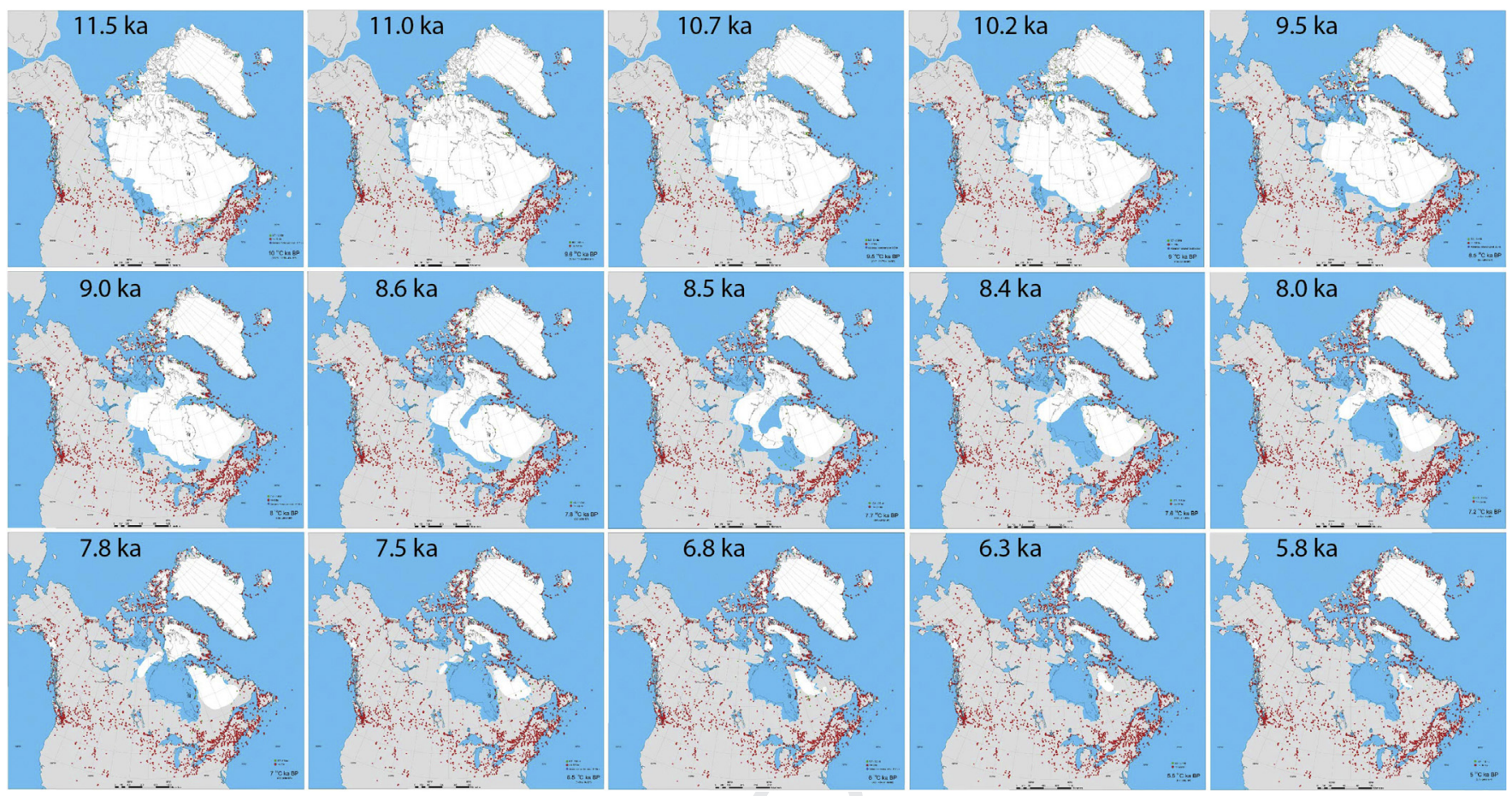

Fig. 3. Laurentide Ice Sheet extents in the Holocene (modified from Dyke et al., 2003).

elevation correction for the Agassiz record should be changed and that the Agassiz constant elevation temperature record will be somewhat different than Renland's, although the first order picture presented in Vinther et al. (2009) will be retained (Lecavalier et al., 2013).

The frequency of melt layers in ice cores has been interpreted in terms of summer temperature (e.g., Fisher et al., 2012). The melt record from Agassiz Ice Cap (Fig. 7) spans the Holocene at 25-year resolution, has been put on the same timescale as Greenland ice core records (GIC005) and has recently been extended to 2009 AD (Fisher et al., 2012). Between 11 and $10 \mathrm{ka}$, the ice core is composed entirely of melted ice (100\% melt); this is followed by declining melt to $5-10 \%$ by $\sim 4 \mathrm{ka}$. Recently, melt has increased to $35 \%$, a melt percentage not routinely experienced since $8 \mathrm{ka}$ (Fig. 7; Fisher et al., 2012). Melt data. The presence of melt layers spanning the Holocene has been documented in the GISP2 ice core (Fig. 7) (Alley and Anandakrishnan, 1995), but melt layers older than $\sim 8$ ka are difficult to detect because air bubbles go into solid solution and this may have resulted in the decline in identified melt layers. Additional melt-layer records exist, but do not span the Holocene (e.g., GrIS Site J, Devon Ice Cap, Penny Ice Cap).

Borehole temperatures have been used to model air temperature history at the GRIP and Dye-3 deep ice core sites, and are useful for identifying millennial-scale trends in annually integrated air temperature and the timing of maximum Holocene warmth (DahlJensen et al., 1998). The reconstruction from GRIP shows a prolonged period of warmth $\left(\sim 2{ }^{\circ} \mathrm{C}\right.$ above 20th century temperature) from $\sim 9$ to $\sim 5 \mathrm{ka}$; the Dye-3 borehole shows a shorter period of warmth on the same order as the GRIP borehole, but occurring later at $\sim 5 \mathrm{ka}$ (Fig. 7). Both time series show cooling until $\sim 2 \mathrm{ka}$, warming until $\sim 1$ ka followed by cooling that culminates in the latter portion of the last millennium, and warming in the last century (Fig. 7; Dahl-Jensen et al., 1998). Air temperature histories derived from borehole temperatures from the GrIS are largely in agreement back to $\sim 5 \mathrm{ka}$, but are slightly different in the early Holocene, likely due to core site elevation changes (the same issue that affects $\delta^{18} \mathrm{O}$ records) and because modeled temperature histories make assumptions about the large air temperature step at the marineisotope-stage 2/1 boundary (Cuffey and Clow, 1997).

Argon and nitrogen isotope ratios from trapped air in ice cores have been used to reconstruct past temperature at GISP2, but thus far continuous records only span the 8.2 ka event and the past 4000 years (Kobashi et al., 2007, 2011). The isotopes indicate a $\sim 2{ }^{\circ} \mathrm{C}$ mean annual temperature decrease from $\sim 3.5$ to $0.5 \mathrm{ka}$, with centennial-scale variability of up to $\sim 2{ }^{\circ} \mathrm{C}$. The record also shows disagreement with $\delta^{18} \mathrm{O}$ from the same ice core that cannot be reconciled by adjusting $\delta^{18} \mathrm{O}$ for elevation change history, thus highlighting some of the challenges, such as changing seasonality of precipitation, with precipitation isotopes (Kobashi et al., 2011).

Finally, a promising new approach to extracting paleo-air temperatures from ice cores uses the time history of the variance spectra of high-precision, high-resolution isotope time series. This method has been applied to NGRIP and seems to capture temperature events missed by direct use of the isotopes themselves (Gkinis et al., 2014).

\subsection{Marine sediments}

Holocene marine sediments from around Greenland and in the Canadian Arctic Island channels are profoundly influenced by coastal and neritic processes. Hence the records reflect processes related to ice-sheet ocean interactions, the flux of Polar and Atlantic water in ocean currents, and variations in the extent and duration of sea-ice cover. The main proxies for reconstructing paleoceanographic conditions include benthic and planktic foraminiferal assemblages, stable isotopes generated from calcareous foraminifers, assemblages of diatoms and dinocysts, and biomarker $\mathrm{IP}_{25}$. Foraminifer, diatom and dinocyst data allow summer sea-surface temperature reconstructions. Diatom, dinocysts and $\mathrm{IP}_{25}$ data also allow sea-ice reconstructions. Another proxy commonly used on the Greenland shelf is ice-rafted detritus (IRD), which is quantified as coarse grain fraction (e.g. $>1 \mathrm{~mm},>2 \mathrm{~mm},>250 \mu \mathrm{m}$ ) counts or 
Table 1

Proxy records from the Arctic Holocene database of Sundqvist et al. (2014) used in this review.

\begin{tabular}{|c|c|c|c|c|c|c|c|c|c|c|}
\hline Site name & $\begin{array}{l}\text { Site ID } \\
\text { Fig. } 1\end{array}$ & $\begin{array}{l}\text { General } \\
\text { location }\end{array}$ & $\begin{array}{l}\text { Included in } \\
\text { matrix in Fig. } 4\end{array}$ & $\begin{array}{l}\text { Latitude } \\
\left({ }^{\circ}\right)\end{array}$ & $\begin{array}{l}\text { Longitude } \\
\left({ }^{\circ}\right)\end{array}$ & $\begin{array}{l}\text { Elevation } \\
(\mathrm{m} \text { asl) }\end{array}$ & Source & Proxy & Climate variable & Citation \\
\hline \multicolumn{11}{|c|}{ Canadian Arctic Islands and Greenland } \\
\hline Agassiz & 1 & $\begin{array}{l}\text { High Canadian } \\
\text { Arctic }\end{array}$ & yes & 80.70 & -73.10 & 1730 & ice & $\begin{array}{l}\text { d180.ice, } \\
\text { ice.melt }\end{array}$ & annual air temp & Vinther et al., 2006, 2009 \\
\hline $\begin{array}{l}\text { Akvaqiak } \\
\text { Lake }\end{array}$ & 2 & Baffin Island & yes & 66.78 & -63.95 & 17 & lake & pollen & July air temp & Fréchette and de Vernal 2009 \\
\hline ARC-3 & 3 & $\begin{array}{l}\text { Central } \\
\text { Canadian Arctic }\end{array}$ & no & 74.27 & -91.11 & -347 & marine & IP25 & spring sea ice & Vare et al., 2009; Belt et al., 2010 \\
\hline BC01 & 4 & $\begin{array}{l}\text { Western } \\
\text { Canadian Arctic }\end{array}$ & yes & 75.18 & -111.92 & 225 & lake & OM, MS, BSi & $\begin{array}{l}\text { summer air } \\
\text { temp }\end{array}$ & Peros et al., 2010 \\
\hline $\begin{array}{l}\text { Big Round } \\
\text { Lake }\end{array}$ & 5 & Baffin Island & no & 69.87 & -68.86 & 195 & lake & MS & $\begin{array}{l}\text { relative glacier } \\
\text { extent }\end{array}$ & Thomas et al., 2010 \\
\hline Braya Sø & 6 & W Greenland & yes & 67.00 & -50.70 & 170 & lake & alkenones & $\begin{array}{l}\text { summer lake } \\
\text { surface temp }\end{array}$ & D'andrea et al., 2011 \\
\hline $\begin{array}{l}\text { Camp } \\
\text { Century }\end{array}$ & 7 & $\begin{array}{l}\text { Greenland Ice } \\
\text { Sheet }\end{array}$ & yes & 77.17 & -61.13 & 1890 & ice & d180.ice & annual air temp & Vinther et al., 2009 \\
\hline DA05 & 8 & W Greenland & no & 68.72 & -51.11 & -335 & marine & forams & annual sea ice & Lloyd et al., 2007 \\
\hline $\begin{array}{l}\text { Devon Ice } \\
\text { Cap }\end{array}$ & 9 & $\begin{array}{l}\text { Eastern } \\
\text { Canadian Arctic }\end{array}$ & yes & 75.32 & -82.50 & & ice & d180.ice & annual air temp & $\begin{array}{l}\text { Fisher et al., 1983, Fisher } \\
\text { unpublished data }\end{array}$ \\
\hline Dye-3 & 10 & $\begin{array}{l}\text { Greenland Ice } \\
\text { Sheet }\end{array}$ & yes & 65.18 & -43.82 & 2620 & ice & d180.ice & annual air temp & Vinther et al., 2006 \\
\hline $\begin{array}{c}\text { Flower } \\
\text { Valley } \\
\text { Lake }\end{array}$ & 11 & S Greenland & no & 65.61 & -37.69 & 73 & lake & $\mathrm{dD}$ & $\begin{array}{l}\text { effective annual } \\
\text { moisture }\end{array}$ & Balascio et al., 2013 \\
\hline GISP2 & 12 & $\begin{array}{l}\text { Greenland Ice } \\
\text { Sheet }\end{array}$ & yes & 72.58 & -38.46 & 3216 & ice & $\begin{array}{l}\text { d180.ice, } \\
\text { d180.ice }\end{array}$ & annual air temp & Alley 2000 \\
\hline GRIP & 13 & $\begin{array}{l}\text { Greenland Ice } \\
\text { Sheet }\end{array}$ & yes & 72.01 & -37.63 & 3230 & ice & d180.ice & annual air temp & Vinther et al., 2006 \\
\hline Hjort Lake & 14 & E Greenland & yes & 76.43 & -18.77 & 114 & lake & chironomids & $\begin{array}{l}\text { summer air } \\
\text { temp }\end{array}$ & Schmidt et al., 2011 \\
\hline $\begin{array}{l}\text { HU84-030- } \\
021\end{array}$ & 15 & Labrador Sea & yes & 58.37 & -57.51 & -2853 & marine & dinocysts & $\begin{array}{l}\text { summer sea } \\
\text { surface temp }\end{array}$ & de Vernal et al., 2001. 2013 \\
\hline $\begin{array}{l}\text { HU90-013- } \\
017\end{array}$ & 16 & Labrador Sea & yes & 58.21 & -48.37 & -3380 & marine & dinocysts & $\begin{array}{l}\text { summer sea } \\
\text { surface temp }\end{array}$ & de Vernal et al., 2013 \\
\hline $\begin{array}{l}\text { HU91-039- } \\
008 \text { PC }\end{array}$ & 17 & Baffin Bay & yes & 77.27 & -74.33 & -663 & marine & dinocysts & $\begin{array}{l}\text { summer sea } \\
\text { surface temp }\end{array}$ & $\begin{array}{l}\text { Levac et al., 2001; de Vernal et al., } \\
2013\end{array}$ \\
\hline Igaliku Lake & 18 & S Greenland & no & 61.00 & -45.43 & 30 & lake & pollen.flux & $\begin{array}{l}\text { summer air } \\
\text { temp }\end{array}$ & Massa et al., 2012 \\
\hline $\begin{array}{l}\text { Iglutalik } \\
\text { Lake }\end{array}$ & 19 & Baffin Island & yes & 66.14 & -66.08 & 90 & lake & pollen & July air temp & Kerwin et al., 2004; Davis 1980 \\
\hline Jake Lake & 20 & Baffin Island & yes & 63.67 & -65.15 & 300 & lake & pollen & July air temp & $\begin{array}{l}\text { Kerwin et al., 2004; Miller et al., } \\
2005\end{array}$ \\
\hline $\begin{array}{l}2004-804- \\
009\end{array}$ & 21 & $\begin{array}{l}\text { Lancaster } \\
\text { Sound }\end{array}$ & yes & 74.19 & -81.20 & -781 & marine & dinocysts & $\begin{array}{l}\text { summer sea } \\
\text { surface temp }\end{array}$ & $\begin{array}{l}\text { Ledu et al., 2010; de Vernal et al., } \\
2013\end{array}$ \\
\hline $\begin{array}{l}\text { MD99- } \\
2227\end{array}$ & 22 & Labrador Sea & yes & 58.21 & -48.37 & -3460 & marine & dinocysts & $\begin{array}{l}\text { summer sea } \\
\text { surface temp }\end{array}$ & $\begin{array}{l}\text { deVernal and Hillaire-Marcel 2006; } \\
\text { de Vernal et al., } 2013\end{array}$ \\
\hline N14 & 23 & S Greenland & no & 59.98 & -44.18 & 101 & lake & BSi & $\begin{array}{l}\text { annual } \\
\text { precipitation }\end{array}$ & Andresen et al., 2004 \\
\hline NAUJG1-1 & 24 & W Greenland & yes & 66.67 & -51.97 & 300 & lake & mineral.content & $\begin{array}{l}\text { summer air } \\
\text { temp }\end{array}$ & Willemse and Törnqvist 1999 \\
\hline NGRIP & 25 & $\begin{array}{l}\text { Greenland Ice } \\
\text { Sheet }\end{array}$ & yes & 75.10 & -42.32 & 2917 & ice & d180.ice & annual air temp & $\begin{array}{l}\text { Vinther et al., 2006; NorthGRIP } \\
\text { members } 2004\end{array}$ \\
\hline North Lake & 26 & W Greenland & yes & 69.24 & -50.03 & 190 & lake & $\begin{array}{l}\text { OM, BSi, } \\
\text { chironomids }\end{array}$ & July air temp & Axford et al., 2013 \\
\hline $\begin{array}{l}\text { Penny Ice } \\
\text { Cap }\end{array}$ & 27 & Baffin Island & yes & 67.25 & -66.75 & 1900 & ice & $\begin{array}{l}\text { d180.ice, } \\
\text { d180.ice }\end{array}$ & annual air temp & Fisher et al., 1998 \\
\hline $\begin{array}{l}\text { Qipisarqo } \\
\text { Lake }\end{array}$ & 28 & S Greenland & yes & 61.00 & -47.75 & 7 & lake & pollen, BSi & July air temp & $\begin{array}{l}\text { Fréchette and de Vernal 2009; } \\
\text { Kaplan et al., } 2002\end{array}$ \\
\hline Renland & 29 & E Greenland & yes & 71.30 & -26.70 & 2350 & ice & $\mathrm{d} 180$ & annual air temp & Vinther et al., 2009 \\
\hline SFL-1 & 30 & W Greenland & yes & 67.08 & -50.28 & 247 & lake & OM & $\begin{array}{l}\text { summer air } \\
\text { temp }\end{array}$ & Willemse and Törnqvist 1999 \\
\hline SP02 & 31 & $\begin{array}{l}\text { Central } \\
\text { Canadian Arctic }\end{array}$ & yes & 68.55 & -83.29 & 220 & lake & OM, MS & $\begin{array}{l}\text { summer air } \\
\text { temp }\end{array}$ & Adams and Finkelstein 2010 \\
\hline SS1381 & 32 & W Greenland & no & 67.01 & -51.10 & 196 & lake & $\begin{array}{l}\text { OM.flux, } \\
\text { mineral.flux }\end{array}$ & $\begin{array}{l}\text { effective annual } \\
\text { moisture }\end{array}$ & Anderson et al., 2012 \\
\hline SS16 & 33 & W Greenland & no & 66.91 & -50.46 & 477 & lake & diatoms & $\begin{array}{l}\text { effective annual } \\
\text { moisture }\end{array}$ & Perren et al., 2012 \\
\hline SS49 & 34 & W Greenland & no & 66.86 & -52.64 & 330 & lake & diatoms & $\begin{array}{l}\text { effective annual } \\
\text { moisture }\end{array}$ & Perren et al., 2012 \\
\hline SS8 & 35 & W Greenland & no & 67.01 & -51.07 & 188 & lake & $\begin{array}{l}\text { mineral.flux, } \\
\text { OM.flux }\end{array}$ & $\begin{array}{l}\text { effective annual } \\
\text { moisture }\end{array}$ & Anderson et al., 2012 \\
\hline KR02 & 42 & $\begin{array}{l}\text { Western } \\
\text { Canadian Arctic }\end{array}$ & yes & 71.34 & -113.78 & 299 & lake & BSi, pollen & July air temp & Peros and Gajewski 2008 \\
\hline
\end{tabular}


Table 1 (continued)

\begin{tabular}{|c|c|c|c|c|c|c|c|c|c|c|}
\hline Site name & $\begin{array}{l}\text { Site ID } \\
\text { Fig. } 1\end{array}$ & $\begin{array}{l}\text { General } \\
\text { location }\end{array}$ & $\begin{array}{l}\text { Included in } \\
\text { matrix in Fig. } 4\end{array}$ & $\begin{array}{l}\text { Latitude } \\
\left({ }^{\circ}\right)\end{array}$ & $\begin{array}{l}\text { Longitude } \\
\left({ }^{\circ}\right)\end{array}$ & $\begin{array}{l}\text { Elevation } \\
(\mathrm{m} \text { asl) }\end{array}$ & Source & Proxy & Climate variable & Citation \\
\hline $\begin{array}{l}2005-804- \\
006\end{array}$ & 36 & Victoria Strait & yes & 68.99 & -106.57 & -118 & marine & dinocysts & $\begin{array}{l}\text { summer sea } \\
\text { surface temp }\end{array}$ & $\begin{array}{l}\text { Ledu et al., 2010; de Vernal et al., } \\
2013\end{array}$ \\
\hline ARC-4 & 37 & Victoria Strait & no & 69.17 & -100.70 & -61 & marine & IP25 & spring sea ice & Belt et al., 2010 \\
\hline ARC-5 & 38 & Dease Strait & no & 68.99 & -106.57 & -112 & marine & IP25 & spring sea ice & Belt et al., 2010 \\
\hline $\begin{array}{l}\text { Ennadai } \\
\text { Lake }\end{array}$ & 39 & $\begin{array}{l}\text { Central } \\
\text { Canadian Arctic }\end{array}$ & yes & 61.17 & -100.92 & 168 & peat & pollen & $\begin{array}{l}\text { summer air } \\
\text { temp }\end{array}$ & $\begin{array}{l}\text { Viau \& Gajewski et al., 2009; } \\
\text { Nichols, } 1975\end{array}$ \\
\hline JR01 & 40 & $\begin{array}{l}\text { Central } \\
\text { Canadian Arctic }\end{array}$ & yes & 69.90 & -95.07 & 120 & lake & pollen & July air temp & Zabenskie and Gajewski 2007 \\
\hline Lake K2 & 41 & N Québec & yes & 58.73 & -65.93 & 167 & lake & chironomids & July air temp & Fallu et al., 2005 \\
\hline LR01 & 43 & N Québec & yes & 58.58 & -75.25 & 170 & lake & pollen & $\begin{array}{l}\text { summer air } \\
\text { temp }\end{array}$ & $\begin{array}{l}\text { Gajewski et al., 1993; Viau \& } \\
\text { Gajewski et al., } 2009\end{array}$ \\
\hline S52/S53 & 44 & $\begin{array}{l}\text { Central } \\
\text { Canadian Arctic }\end{array}$ & yes & 59.89 & -104.21 & 395 & peat & $\mathrm{d} 13 \mathrm{C}, \mathrm{d} 13 \mathrm{C}$ & July air temp & Tillman et al., 2010 \\
\hline $\begin{array}{l}\text { Toronto } \\
\text { Lake }\end{array}$ & 45 & $\begin{array}{l}\text { Central } \\
\text { Canadian Arctic }\end{array}$ & no & 63.72 & -109.35 & 414 & lake & d180.cellulose & $\begin{array}{l}\text { effective annual } \\
\text { moisture }\end{array}$ & $\begin{array}{l}\text { Wolfe et al., 1996; MacDonald et al., } \\
1993\end{array}$ \\
\hline Unit Lake & 46 & $\begin{array}{l}\text { Central } \\
\text { Canadian Arctic }\end{array}$ & no & 59.40 & -97.49 & 294 & lake & ARM/IRM & $\begin{array}{l}\text { effective annual } \\
\text { moisture }\end{array}$ & Camill et al., 2012 \\
\hline $\begin{array}{l}\text { Whatever } \\
\text { Lake }\end{array}$ & 47 & $\begin{array}{l}\text { Central } \\
\text { Canadian Arctic }\end{array}$ & no & 64.68 & -97.05 & & lake & d180.cellulose & $\begin{array}{l}\text { effective annual } \\
\text { moisture }\end{array}$ & Edwards et al., 1996 \\
\hline
\end{tabular}

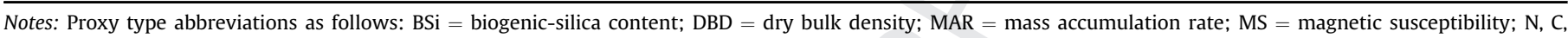
$\mathrm{S}=$ nitrogen, carbon, sulfur; $\mathrm{OM}=$ organic-matter content; $\mathrm{TOC}=$ total organic carbon. Oldest and youngest ages are in calendar years before $1950 \mathrm{AD}$ (yr $\mathrm{BP}$ ).

weight percentages. The presence of IRD requires tidewater glaciers and transport of coarse material to the shelf by icebergs. It is often inferred that the presence of IRD in shelf sediments relates to cooling because it records iceberg calving, which in turn contributes to cooling and freshening of surface waters. However, IRD could likewise increase when warmer ocean currents melt more ice. Thus, IRD can be an ambiguous proxy. We note that when using ocean sediment records, it is often difficult to disentangle changes in ocean currents, surface temperature, and changes in adjacent ice sheets. Nevertheless, we summarize the broad scale inferredtemperature patterns from around Greenland and the Canadian Arctic channels, focusing on the timing of inferred warmest conditions and the pattern of late Holocene cooling.

\subsubsection{Canadian Arctic Island channels and northern Baffin Bay}

In the Canadian Arctic, there are many marine records of paleoceanographic changes based on diverse approaches. In northern Nares Strait, foraminiferal assemblages, stable isotope analyses and sediment lithofacies data from HLY03-05GC (Table 2) were used to reconstruct Holocene conditions (Jennings et al., 2011a). High marine productivity in Hall Basin between 9 and 6 ka suggests reduced sea-ice cover as well as throughflow of nutrient-rich Pacific Water. The late Holocene is poorly resolved in HLY03-05GC, but the slow sedimentation rates and heavier carbon isotope values suggest cooler conditions, increased sea-ice cover and decreased productivity after 6 ka. Other paleoceanographic studies in southern Nares Strait indicated an increase in spring sea ice beginning $\sim 3 \mathrm{ka}$ on the basis of dinocyst assemblages, $\mathrm{IP}_{25}$ and other biological tracers (Levac et al., 2001; Knudsen et al., 2008; Belt et al., 2010).

In Barrow Strait, Pienkowski et al. (2012) used several proxies to reconstruct a transition at 7.8 to $6.7 \mathrm{ka}$ from a period of more open water to one trending toward increasing sea ice (Fig. 8). By $6.7 \mathrm{ka}$ they inferred that conditions were similar to present. Glacioisostatic shallowing of the channels within the Canadian Arctic $\mathrm{Ar}$ chipelago reduced and eventually excluded the throughflow of the Atlantic water layer from the Arctic Ocean.

Vare et al. (2009) used $\mathrm{IP}_{25}$ to reconstruct spring sea-ice conditions in the Barrow Strait at Site ARC-3 (Table 1; Fig. 1) from 10 to $0.4 \mathrm{ka}$. Low occurrence of spring sea ice inferred from $\mathrm{IP}_{25}$ occurred from 10 to 6 ka. From 6 to 4 ka spring sea ice increased gradually. An increase in $\mathrm{IP}_{25}$ from 4 to $3 \mathrm{ka}$ and continuing to the end of the record suggests a strong increase in spring productivity related to sea ice.

Ledu et al. (2008, 2010a, b) reconstructed dense seasonal sea-ice cover through the Holocene from the Northwest Passage, including Dease Strait (ARC-5), Lancaster Sound (core 2004-804-009) and Barrow Strait (ARC-3; Table 1; Fig. 1). They found slightly increasing sea ice since $3 \mathrm{ka}$ in Lancaster Sound and Dease Strait. They also reconstructed summer sea surface temperature changes with maxima up to $3^{\circ} \mathrm{C}$ higher than present between 8.5 and $5.5 \mathrm{ka}$, with peak Holocene warmth between 6.5 and $5.5 \mathrm{ka}$ in Lancaster Sound, which they associated with a strengthened influence of the WGC. The temperature and sea-ice reconstructions from Lancaster Sound match well those from the northern Baffin Bay (Levac et al., 2001; de Vernal et al., 2013); both records show a gradual cooling of surface water in summer and increased seasonal extent of sea-ice cover from 5.5 ka to present.

\subsubsection{Western Greenland shelf}

The marine records from the western Greenland shelf are particularly complex as they are influenced by meltwater discharge and ice dynamics along the GrIS margins in addition to large-scale ocean circulation patterns. Hence, the tracers of benthic and epipelagic conditions may capture complementary signals that may provide apparent discrepancies. For example, high surface air temperatures responsible for enhanced melting also result in freshening of surface water and increased stratification, in turn fostering large annual amplitude of sea-surface temperature with dense winter sea ice. Although complex, the western Greenland shelf records are particularly interesting because high sedimentation rates permit reconstruction with centennial resolution or higher.

Nørgaard-Pedersen and Mikkelsen (2009) studied sediment from Narsaq Sound in South Greenland (Ga3-2) and proposed maximum retreat of glaciers $\sim 8 \mathrm{ka}$ and cooling at $4.8 \mathrm{ka}$. Farther offshore, from Holsteinburg Dyb, Erbs-Hansen et al. (2013) present a 6700-yr-long record of variations in Polar and Atlantic water masses of the West Greenland Current in Holsteinsburg Dyb (GA306-GC3; GA306-GC4) using benthic foraminiferal assemblages, which suggest that cooling took place after $3.8 \mathrm{ka}$.

North of Davis Strait in eastern Baffin Bay, Disko Bugt and the adjacent shelf has been an area of intense focus over the past decade (Moros et al., 2006b; Lloyd et al., 2007; Perner et al., 2012; Jennings et al., 2014; Ouellet-Bernier et al., 2014; Seidenkrantz 


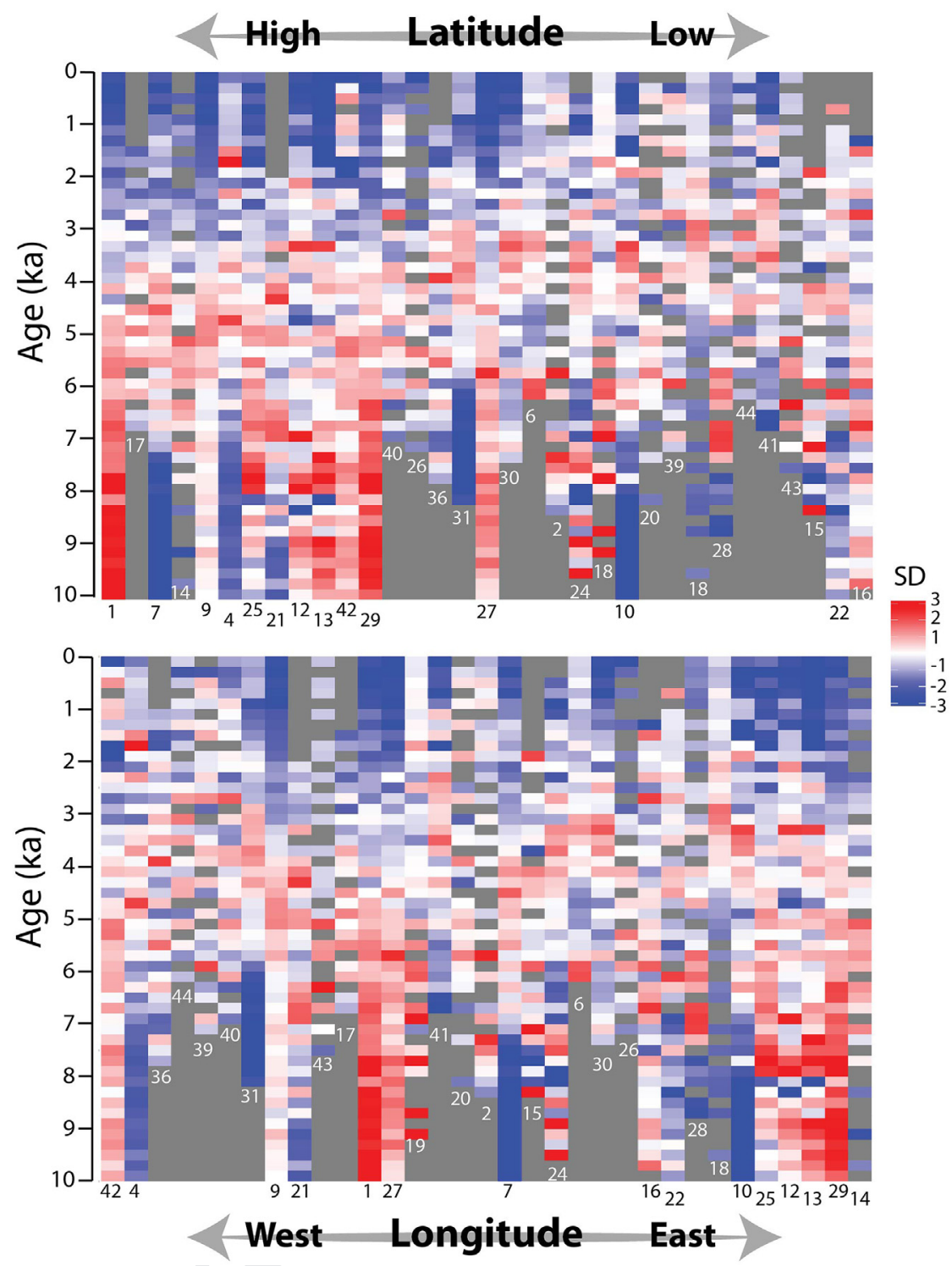

Fig. 4. Heat map of temperature-sensitive records in the Arctic Canada/Greenland region of the Arctic Holocene database (Sundqvist et al., 2014). Numbers refer to site IDs listed in Table 1 and shown on Fig. 1. Records are arranged from left to right in order of decreasing north latitude (top) and west longitude (bottom). Colors correspond to standard deviations with respect to the interval of common overlap. Missing values are indicated in gray. (For interpretation of the references to color in this figure legend, the reader is referred to the web version of this article.)

et al., 2008; Sha et al., 2014). Using benthic foraminifers in a highresolution record beginning $7.3 \mathrm{ka}$ (core MSM 343300), Perner et al. (2012) tracked changes in sub-surface water mass, which records properties of the West Greenland Current. From 7.3 to 6.2 ka the benthic fauna indicate strong Irminger Current flux and enhanced ice sheet meltwater production; thermal maximum conditions are recorded from 6.2 to $3.5 \mathrm{ka}$ (Fig. 8). In the same core, dinocyst assemblages indicate the maximum sea surface temperature $\sim 6 \mathrm{ka}$, with significant cooling pulses centered $\sim 4.5$ and $\sim 1.5$ ka (OuelletBernier et al., 2014). A general trend toward cooling and freshening of sub-surface water masses occurred in Disko Bugt at 3.5 ka (Lloyd et al., 2007; Perner et al., 2012) as suggested from benthic faunal changes, implying a weakening the West Greenland Current relative to increasing influence of the East Greenland Current.

\subsubsection{East Greenland shelf/margin}

Several studies have reconstructed Holocene sea-ice variations and warm saline Atlantic Water inflow via the Norwegian Atlantic
Current to Fram Strait during the Holocene (core MSM5/5-712-2; Müller et al., 2012; Werner et al., 2013; de Vernal et al., 2013, Fig. 8). Werner et al. (2013) reconstructed cooling from $5.2 \mathrm{ka}$ to the present associated with increased polar water flux and southward and eastward advancing sea-ice margin. Sea-ice advection to Fram Strait was synchronous with full postglacial flooding of the Arctic Ocean shelves $\sim$ ka (Bauch et al., 2001).

The East Greenland shelf in the region of Denmark Strait $\left(68^{\circ} \mathrm{N}\right)$ is influenced by the East Greenland Current, which carries both cold low-salinity Polar Water at the surface and chilled return Atlantic Water and relatively warm saline Irminger Current in the subsurface (Jennings et al., 2011b). The sediments from the East Greenland shelf include the signal of these currents in addition to sedimentary input related to the ice dynamics along the east GrIS margins. Andrews et al. (1997) found increased IRD, which they interpreted as a manifestation of advance of Greenland glaciers into tidewater and cooling beginning $6 \mathrm{ka}$. In the Nansen Trough (JM961206/1-GC, JM96-1207/1-GC), Jennings et al. (2002) related 

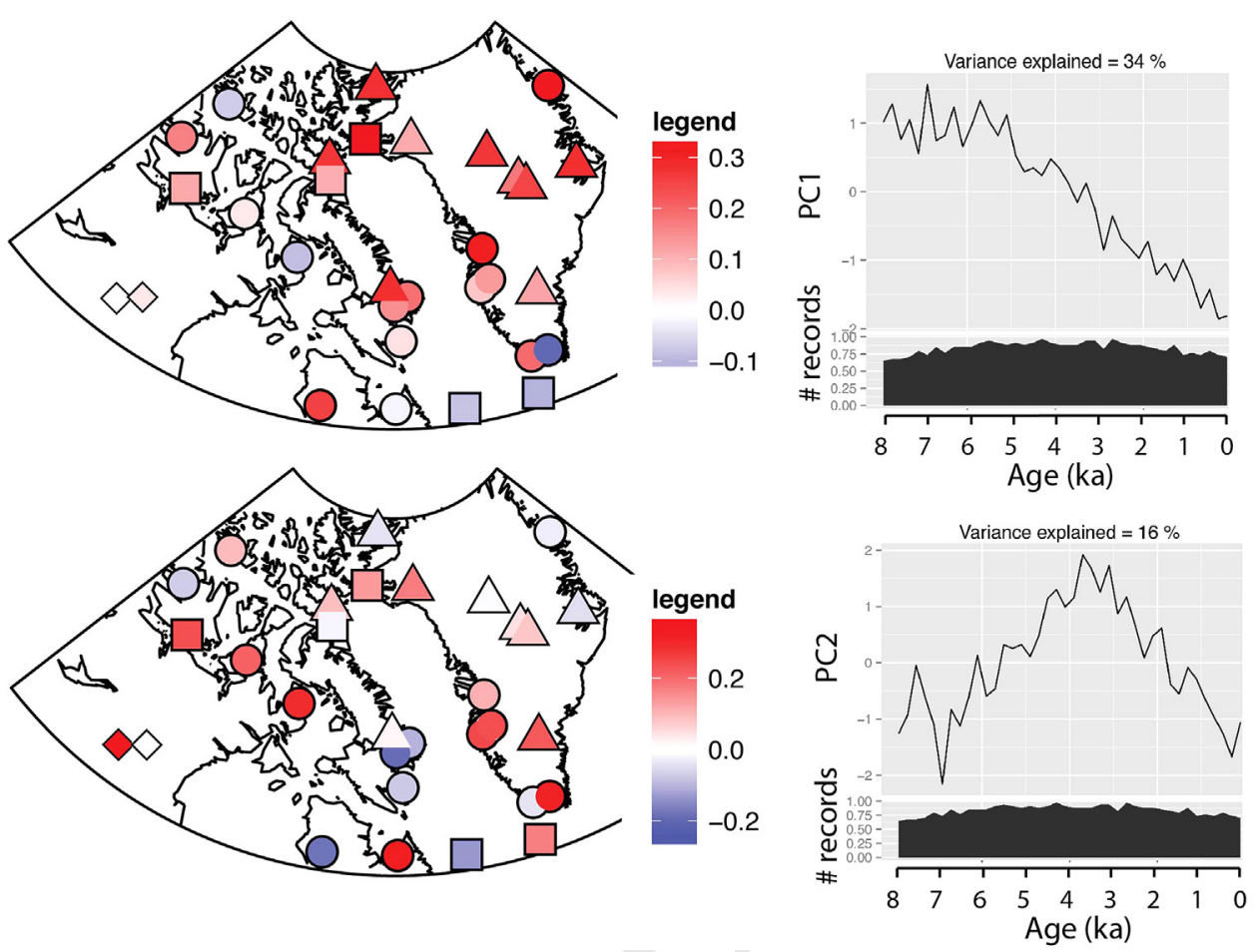

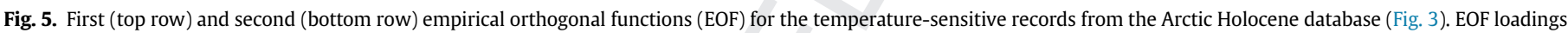

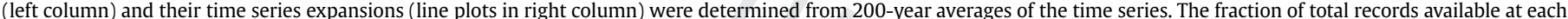
time step is shown in the filled-area plots in the right column. Triangles = glacier ice; circles = lake sediment; squares = marine sediment; diamonds = peat.

changes in benthic foraminiferal assemblages, stable isotopes and increased IRD fluxes to a shift toward cooler conditions at $\sim 4.7 \mathrm{ka}$. Dinocyst data from the same area (JM96-1207/1-GC) provide some information about sea-surface conditions, which were marked by very low salinity peaks until $\sim 4.5 \mathrm{ka}$ as the result of meltwater discharge, and also by increased seasonal sea-ice cover after $3.5 \mathrm{ka}$ (Solignac et al., 2006).

In the Kangerlussuaq Trough, summer sea surface temperatures were reconstructed from MD99-2322 for the last 8000 years at 100 -year resolution based on planktic foraminiferal assemblages (Jennings et al., 2011b, Fig. 8). These data show thermal maximum conditions between 8.1 and $3.5 \mathrm{ka}$, with the warmest millennium being between 8.0 and $7.0 \mathrm{ka}$, and cool intervals between 7.0 and $6.5 \mathrm{ka}$ and at 4.9 and $4.5 \mathrm{ka}$. This is not exactly in phase with the temperature estimates by Solignac et al. (2006), who found large changes salinity and the annual amplitude of temperatures, suggesting variations in the upper water mass stratification. Nevertheless, at both sites, more sea ice and/or cold conditions are inferred after $3.5 \mathrm{ka}$, thus supporting cooling with increased Polar Water flux and advance of GrIS into tidewater. Andresen et al. (2004) reconstructed August sea surface temperature based on diatom assemblages in cores from the Kangerlussuaq Trough, which are generally consistent with a slight cooling beginning at 3 ka nearby from the east Greenland shelf (HU93030-19A). Farther south, in the Sermilik Trough (cores Fox04G/05R), Andresen et al. (2013) also inferred cooling beginning 3.6 ka based on foraminiferal assemblages extending back to $5.8 \mathrm{ka}$.

\subsection{Coastal records of Holocene oceanic change in Greenland}

The scattered occurrence of bivalve shells, whalebones and driftwood has been used to infer Holocene paleoceanographic changes in the study area. The first indication of a Holocene thermal maximum in Greenland was the shells of the common blue mussel
(Mytilus edulis) in raised marine deposits in central East Greenland (Nathorst, 1901). Mytilus edulis does not live in the region at the present, but its shells are fairly common in Holocene deposits, and the temporal and spatial distribution of the species was reviewed by Hjort and Funder (1974), Dyke et al. (1996) and Bennike and Wagner (2013). Radiocarbon ages show that the species was present at least from 9.5 to $5.4 \mathrm{ka}$. Shells of the species are most common in the inner fjords where summer temperatures are higher than at the outer coast. However, the oldest ages come from the outer coast that was deglaciated first. The timing of the local extinction of the species is poorly constrained, because raised deposits younger than the mid-Holocene are rare. The former presence of Mytilus edulis in East Greenland indicates that the temperature of the seawater close to the coast was higher than at present, and the summer was longer. In West Greenland, the occurrence of another marine bivalve, Zirphaea crispata, was taken as an indication of the Holocene thermal maximum in that region (Jensen, 1905). Five thermophillic bivalve species existed in West Greenland from 9 to 6 ka (Funder and Weidick, 1991). As in East Greenland, the last occurrence of warm-water indicators around Baffin Bay is poorly constrained because the number of dated marine bivalves of any type is very low in the late Holocene (Dyke et al., 1996).

Driftwood on raised beaches is more rare in Greenland than in Svalbard or Arctic Canada. Driftwood can only cross the Arctic Ocean if it is carried by sea ice, but there also must be open water along the coast for driftwood to strand on the beach. In central North Greenland driftwood is extremely rare, which reflects the perennial sea ice found along the shores (Kelly and Bennike, 1992), whereas driftwood is more common in eastern North Greenland, where there is open water in some areas during the short summer (Bennike, 1987). A compilation of driftwood ages from Greenland reveals a mid-Holocene peak from $\sim 7$ to $5 \mathrm{ka}$. However, it is not straight-forward to interpret the frequency of driftwood ages. No 
Table 2

Records discussed in text in addition to those in the Arctic Holocene database of Sundqvist et al. (2014).

\begin{tabular}{|c|c|c|c|c|c|c|c|}
\hline Site name & $\begin{array}{l}\text { Site } \\
\text { ID } \\
\text { Fig. } 1\end{array}$ & Lat & Lon & Citation & Source & Proxy & Climate variable \\
\hline HLY03-05GC & 48 & 81.62 & -63.26 & Jennings et al., 2011b & marine & benthic and planktic foraminifers, stable isotopes, sediment & $\begin{array}{l}\text { sea ice, marine } \\
\text { productivity }\end{array}$ \\
\hline $86027-144$ & 49 & 74.26 & -91.24 & Pienkowski et al., 2012 & marine & $\begin{array}{l}\text { Microfossils (dinocysts, non-pollen palynomorphs, benthic and } \\
\text { planktic foraminifers) d } 180 \text { and d13C from foraminifers, } \\
\text { sediment(dinocysts, non-pollen palynomorphs, benthic and } \\
\text { planktonic foraminifera), foraminiferal d } 180 \text { and } d 13 \mathrm{C} \text {, } \\
\text { andsedimentology }\end{array}$ & sea ice \\
\hline Ga3-2 & 50 & 60.94 & -46.16 & $\begin{array}{l}\text { Nørgaard-Pedersen and } \\
\text { Mikkelsen } 2009\end{array}$ & marine & sediment & retreat of glaciers \\
\hline GA306-GC3* & 51 & 66.63 & -54.21 & Erbs-Hansen et al., 2013 & marine & benthic foraminifers & $\begin{array}{l}\text { variations in Polar } \\
\text { and Atlantic water } \\
\text { masses }\end{array}$ \\
\hline GA306-GC4 & 52 & 66.75 & -53.94 & Erbs-Hansen et al., 2013 & marine & benthic foraminifers & $\begin{array}{l}\text { variations in Polar } \\
\text { and Atlantic water } \\
\text { masses }\end{array}$ \\
\hline MSM 343300* & 53 & 68.47 & -54 & Perner et al., 2012 & marine & benthic foraminifers & $\begin{array}{l}\text { sub-surface water } \\
\text { mass }\end{array}$ \\
\hline MSM 343300* & 53 & 68.47 & -54 & $\begin{array}{l}\text { Ouellet-Bernier et al., } \\
2014\end{array}$ & marine & dinocysts & $\begin{array}{l}\text { summer sea } \\
\text { surface } \\
\text { tempertaure, sea } \\
\text { ice }\end{array}$ \\
\hline MSM5/5-712-2 & NA & 78.92 & 6.77 & $\begin{array}{l}\text { Müller et al., 2012; } \\
\text { Werner et al., 2013; de } \\
\text { Vernal et al., } 2013\end{array}$ & marine & IP25, sediment, planktic foraminifers, dinocysts & $\begin{array}{l}\text { sea ice, Atlantic } \\
\text { water inflow }\end{array}$ \\
\hline $\begin{array}{l}\text { JM96-1206/1- } \\
\text { GC and } \\
\text { JM96-1207/ } \\
\text { 1-GC }\end{array}$ & 55 & 68.1 & -29.43 & $\begin{array}{l}\text { Jennings et al., 2002; } \\
\text { Solignac et al., } 2006\end{array}$ & marine & benthic foraminifers, stable isotopes, sediment, dinocysts & $\begin{array}{l}\text { sub-surface water } \\
\text { mass, sea-surface } \\
\text { condition }\end{array}$ \\
\hline MD99-2322 & 56 & 67.14 & -30.83 & Jennings et al., 2011a & marine & planktic foraminifers & $\begin{array}{l}\text { summer sea- } \\
\text { surface } \\
\text { temperatures }\end{array}$ \\
\hline HU93030-19A & 57 & 67.15 & -30.82 & Andersen et al. 2004 & marine & diatoms & $\begin{array}{l}\text { August sea-surface } \\
\text { temperatures }\end{array}$ \\
\hline Fox04G & 58 & 65.56 & -37.46 & Andresen et al., 2013 & marine & benthic and planktic foraminifers & $\begin{array}{l}\text { sea-surface } \\
\text { conditions }\end{array}$ \\
\hline Fox05R & 59 & 65.56 & -37.44 & Andresen et al., 2013 & marine & benthic and planktic foraminifers & $\begin{array}{l}\text { sea-surface } \\
\text { conditions }\end{array}$ \\
\hline Disraeli Fjord & 60 & 82.87 & -73.49 & Antoniades et al., 2011 & marine & redox sediment properties, organic indicators & $\begin{array}{l}\text { presence/absence } \\
\text { of ice shelves }\end{array}$ \\
\hline $\begin{array}{l}\text { DV09, Devon } \\
\text { Island }\end{array}$ & 61 & 75.58 & -89.32 & $\begin{array}{l}\text { Courtney-Mustaphi and } \\
\text { Gajewski, } 2013\end{array}$ & Lake & sediments & temp \\
\hline $\begin{array}{l}\text { Lower Murray } \\
\text { Lake, } \\
\text { Ellesmere } \\
\text { Island }\end{array}$ & 62 & 81.35 & -69.53 & Cook et al., 2009 & Lake & varved sediments & July air temp \\
\hline Baird Inlet & 63 & 78.49 & -76.78 & Hyvärinen 1985 & Lake & pollen & temp \\
\hline $\begin{array}{l}\text { Victoria Island, } \\
\text { Lake WB02 }\end{array}$ & 64 & 72.29 & -109.87 & Fortin and Gajewski 2009 & Lake & chironomids & temp \\
\hline RS36 & 65 & 72.58 & -95.07 & Gajewski 1995 & Lake & pollen & temp \\
\hline RS29 & 66 & 73.13 & -95.28 & Gajewski 1995 & Lake & pollen & temp \\
\hline Lake PW02 & 67 & 74.07 & -97.77 & $\begin{array}{l}\text { Finkelstein and Gajewski } \\
2008\end{array}$ & Lake & BSi, diatoms & temp \\
\hline Lake PW03 & 68 & 73.12 & -96.68 & $\begin{array}{l}\text { Finkelstein and Gajewski } \\
2007\end{array}$ & Lake & BSi, diatoms & temp \\
\hline Caribou Lake & 69 & 65.21 & -83.8 & Rolland et al., 2008 & Lake & chironomids & August temp \\
\hline Lake CF8 & 70 & 70.56 & -68.95 & Axford et al., 2009, 2011 & Lake & chironomids & summer temp \\
\hline Lake CF3 & 71 & 70.53 & -68.37 & Briner et al., 2006 & Lake & chironomids & summer temp \\
\hline $\begin{array}{l}\text { Patricia Bay } \\
\text { Lake }\end{array}$ & 72 & 68.5 & -70.47 & Kerwin et al., 2004 & Lake & pollen & July air temp \\
\hline Fog Lake & 73 & 67.18 & -63.25 & $\begin{array}{l}\text { Fréchette et al., 2006, } \\
2008\end{array}$ & Lake & pollen & July air temp \\
\hline Lake E & 74 & 67 & -50.7 & D'Andrea et al., 2011 & Lake & alkenones & $\begin{array}{l}\text { summer lake } \\
\text { surface temp }\end{array}$ \\
\hline Lake SS1220 & 75 & 67.05 & -51.22 & Olsen et al., 2012a & Lake & redox-sensitive elements & NAO index \\
\hline Langesø & 76 & 75.37 & -58.6 & Fredskild 1985 & Lake & pollen, beetles, stickleback fishes & temp \\
\hline Rundesø & 77 & 75.37 & -58.6 & Fredskild 1985 & Lake & pollen, beetles, stickleback fishes & temp \\
\hline Qeqertat & 78 & 77.5 & -66.65 & Fredskild 1985 & Lake & pollen, beetles, stickleback fishes & temp \\
\hline Nordvestø & 79 & $\begin{array}{l}76.74 \\
\text { and } \\
76.73\end{array}$ & $\begin{array}{l}-73.21 \\
\text { and }-73.18\end{array}$ & Bennike et al., 2008a & peat & macrofossils & temp \\
\hline $\begin{array}{l}\text { Kap Inglefield } \\
\text { Sø }\end{array}$ & 80 & 82.17 & -30.57 & Blake et al., 1992 & Lake & sediments, algal (Scenedesmus) & temp, ice cover \\
\hline
\end{tabular}


Table 2 (continued)

\begin{tabular}{|c|c|c|c|c|c|c|c|}
\hline Site name & $\begin{array}{l}\text { Site } \\
\text { ID } \\
\text { Fig. 1 }\end{array}$ & Lat & Lon & Citation & Source & Proxy & Climate variable \\
\hline Klaresø & 81 & 83.62 & -30.78 & Fredskild 1969 & Lake & pollen & temp \\
\hline Kaffeklubben Sø & 82 & 83.52 & -28.35 & Perren et al., 2012 & Lake & diatoms, chrysophysts & temp \\
\hline Bliss Lake & 83 & 81.6 & -16.67 & Olsen et al., 2012b & Lake & d13C, TOC & temp \\
\hline Sommersø & 84 & 80.02 & -22.65 & $\begin{array}{l}\text { Fredskild 1969; Funder } \\
\text { and Abrahamsen } 1988\end{array}$ & Lake & pollen & temp \\
\hline Lille Sneha Sø & 85 & 79.53 & -23.88 & $\begin{array}{l}\text { Wagner and Bennike, } \\
2015\end{array}$ & Lake & chironomids, water flea, OM & temp \\
\hline $\begin{array}{l}\text { A small lake } \\
\text { south of } \\
\text { Skallingen }\end{array}$ & 86 & 79.53 & -23.88 & $\begin{array}{l}\text { Bennike and Weidick } \\
2001\end{array}$ & Lake & macrofossils, $\mathrm{OC}, \mathrm{CaCO} 3$ & temp \\
\hline Duck Lake & 87 & 76.13 & -18.61 & $\begin{array}{l}\text { Klug et al., 2009b; } \\
\text { Schmidt et al., } 2011\end{array}$ & Lake & chironomids & temp \\
\hline Melles Lake* & 88 & 75.33 & -19.92 & Klug et al., 2009a & Lake & $\mathrm{OM}$ & temp \\
\hline Dødis Sø & 89 & 75.32 & -20.05 & $\begin{array}{l}\text { Björck and Persson 1981; } \\
\text { Björck et al., } 1994\end{array}$ & Lake & pollen & summer temp \\
\hline Peters Bugt Sø & 90 & 75.32 & -19.67 & $\begin{array}{l}\text { Björck and Persson 1981; } \\
\text { Björck et al., } 1994\end{array}$ & Lake & pollen & summer temp \\
\hline Ailsa Sø & 91 & 74.55 & -18.86 & Björck and Persson 1981 & Lake & pollen & summer temp \\
\hline $\begin{array}{l}\text { Germania Havn } \\
\text { Sø }\end{array}$ & 92 & 74.5 & -20.63 & $\begin{array}{l}\text { Bennike and Wagner } \\
2012\end{array}$ & Lake & macrofossils, caddis flies & temp \\
\hline Boresø & 93 & 73.33 & -25.22 & Bennike et al., 2008b & Lake & pollen, macrofossils, cladocerans, geochemistry & temp \\
\hline Lake N1 & 94 & 72.72 & -22.45 & Wagner and Melles 2002 & Lake & pollen & temp \\
\hline Basaltsø* & 95 & 72.7 & -22.48 & $\begin{array}{l}\text { Wagner et al., 2000; } \\
\text { Cremer et al., } 2001\end{array}$ & Lake & geochemical data, pollen, diatoms & temp \\
\hline Lake B1 & 96 & 72.7 & -22.48 & Wagner et al., 2005 & Lake & chironomids & temp \\
\hline Lake Sisi 12 & 97 & 66.98 & -53.72 & $\begin{array}{l}\text { Wagner and Bennike } \\
2012\end{array}$ & Lake & macrofossils & temp \\
\hline Lake Sisi 14 & 98 & 66.98 & -53.73 & $\begin{array}{l}\text { Wagner and Bennike } \\
2012\end{array}$ & Lake & macrofossils & temp \\
\hline Lake Sisi 15 & 99 & 66.96 & -53.68 & $\begin{array}{l}\text { Wagner and Bennike } \\
2012\end{array}$ & Lake & macrofossils & temp \\
\hline Kulusuk Lake* & 100 & 65.56 & -37.11 & Balascio et al., 2015 & Lake & geochemical data & glacier extent \\
\hline
\end{tabular}

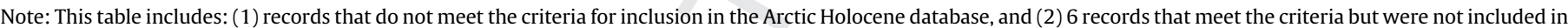

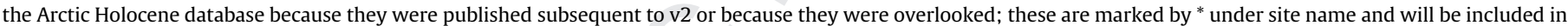
an updated version of the database and will posted at NOAA-Paleoclimatology. OC: organic Carbon, TOC: total organic Carbon, CaCO3: carbonates.

driftwood has been collected that dates from the first two millennia of the Holocene, and this period may have been characterised by perennial sea ice in North and Northeast Greenland. Along the north coast of Peary Land in North Greenland, Funder et al. (2011) dated 56 pieces of driftwood. Thirteen were dated to the period $0.14-0 \mathrm{ka}, 12$ to $0.97-0.57 \mathrm{ka}, 6$ to $1.9-1.8 \mathrm{ka}$, and the rest of the ages are scattered from 7.9 to $2.6 \mathrm{ka}$. The best-developed beach ridges in the region are dated to 8.5 to $6 \mathrm{ka}$, which is taken to mark

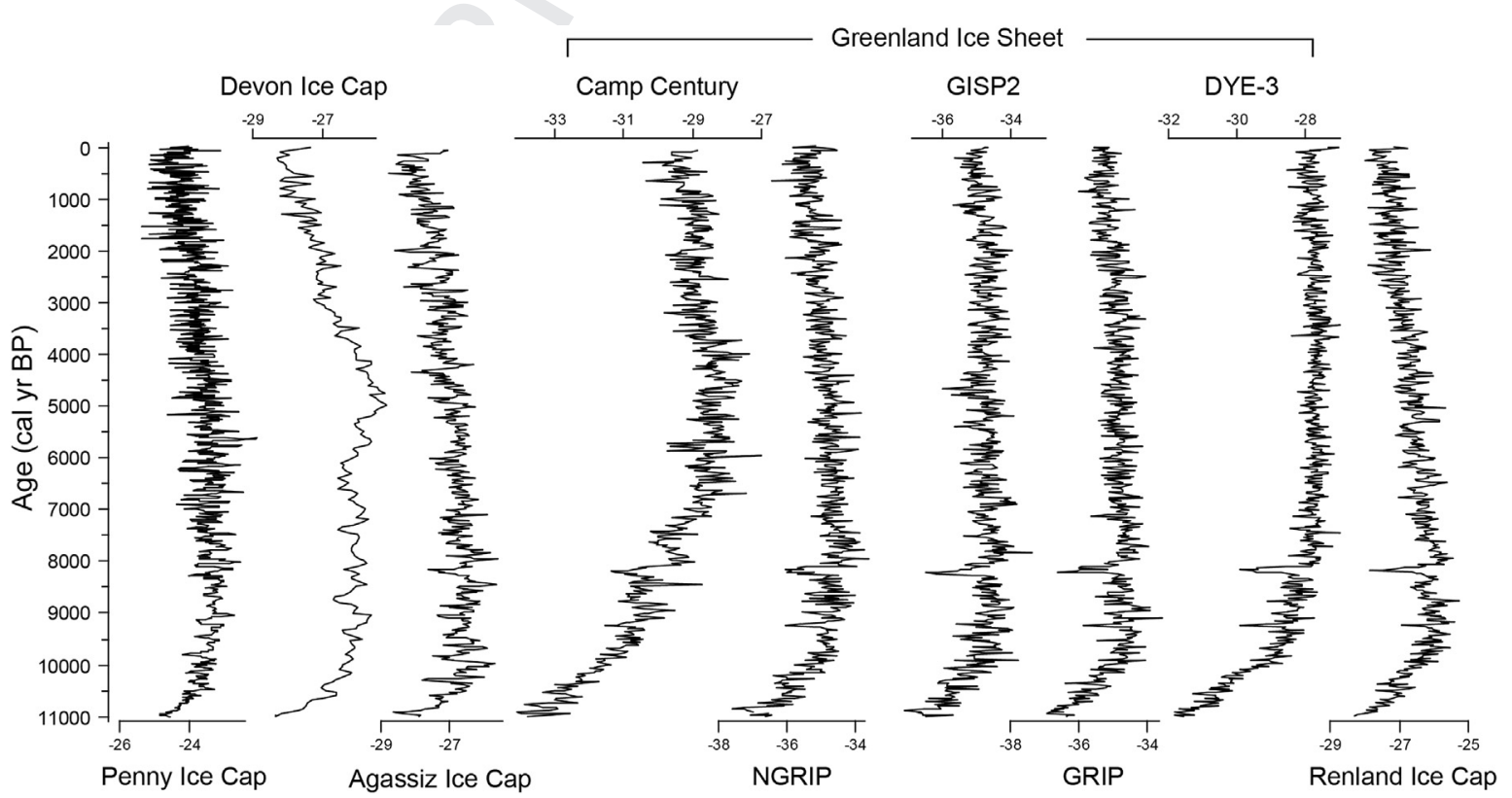

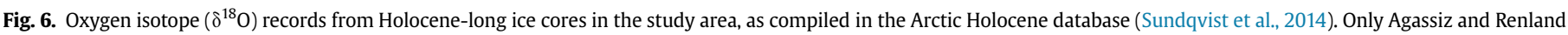
Ice Cap data are corrected for elevation change (Vinther et al., 2009). Penny Ice Cap data are from the 1995 core. 


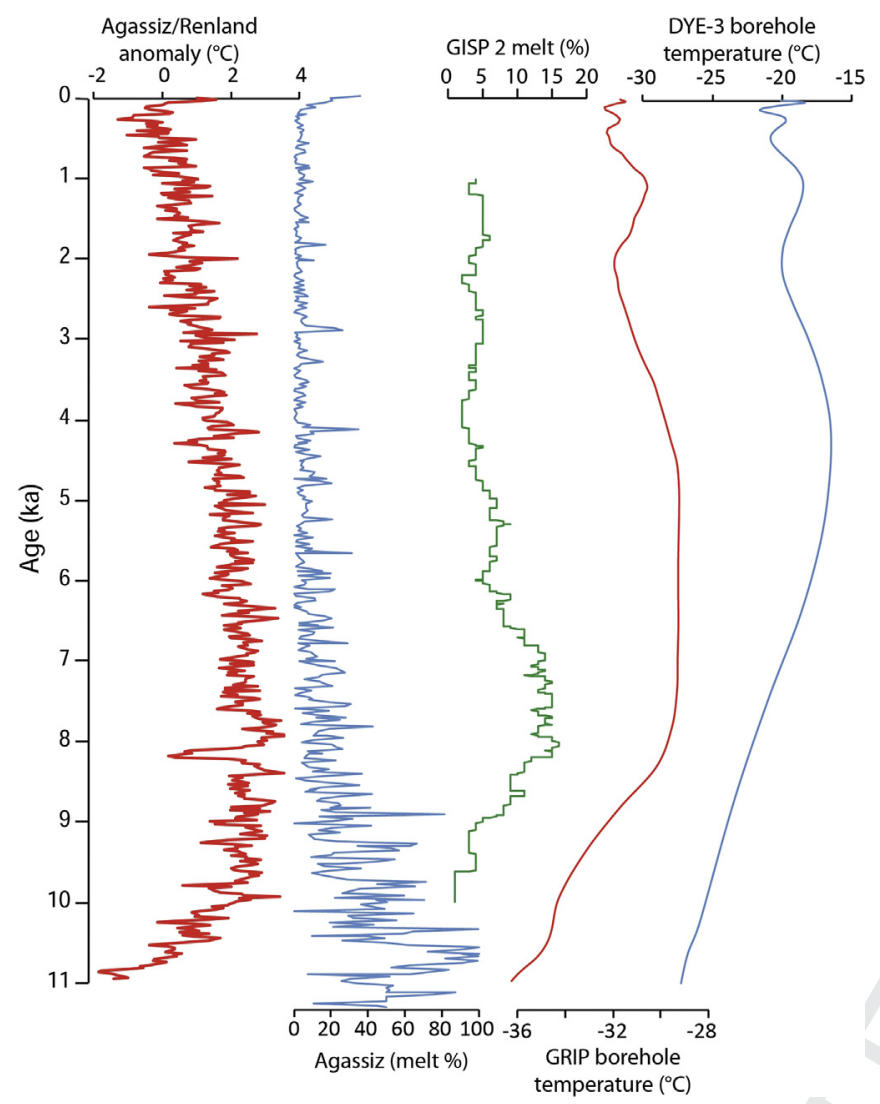

Fig. 7. Selected ice core records. Agassiz + Renland $\delta^{18} \mathrm{O}$ from Vinther et al. (2009); Agassiz melt record from Fisher et al. (2012); GISP2 melt record from Alley and Anandakrishnan (1995); borehole temperature data from Dahl-Jenson et al. (1998).

the sea-ice minimum and temperature maximum (Funder et al., 2011).

Investigations of Disraeli Fjord, Northern Ellesmere Island revealed the presence of ice shelves by the analysis of redox sediment properties and organic indicators (Antoniades et al., 2011). The data show overall Holocene cooling; the fjords were not blocked by ice shelves prior to $4 \mathrm{ka}$, and were periodically blocked by ice shelves after $4 \mathrm{ka}$. However, according to England et al. (2008), the lack of driftwood and whales bones in fjords from the same area after $5.5 \mathrm{ka}$ seems to indicate that the ice shelves may have formed earlier.

\subsection{Lacustrine sediments}

Lake sediments permit diverse methods of reconstructing terrestrial paleoclimate conditions, and offer broad geographic coverage across our study region. Lake sediments preserve numerous biological, physical and chemical indicators of past climate and of aquatic and terrestrial environmental conditions. An increasing number of biological and geochemical training sets facilitate quantitative assessments of past environmental variables (e.g., Kerwin et al., 2004; Whitmore et al., 2005; Shanahan et al., 2013). Importantly, in this treeless study region lakes are unique in providing abundant continuous archives of terrestrial climate history beyond the ice caps and the GrIS, thus complementing icecore derived records that capture atmospheric conditions over large ice masses.

Across the Canadian Arctic Islands and Greenland, lakes and their catchments experienced deglaciation, and in some cases isostatic emergence from the marine environment, at various times
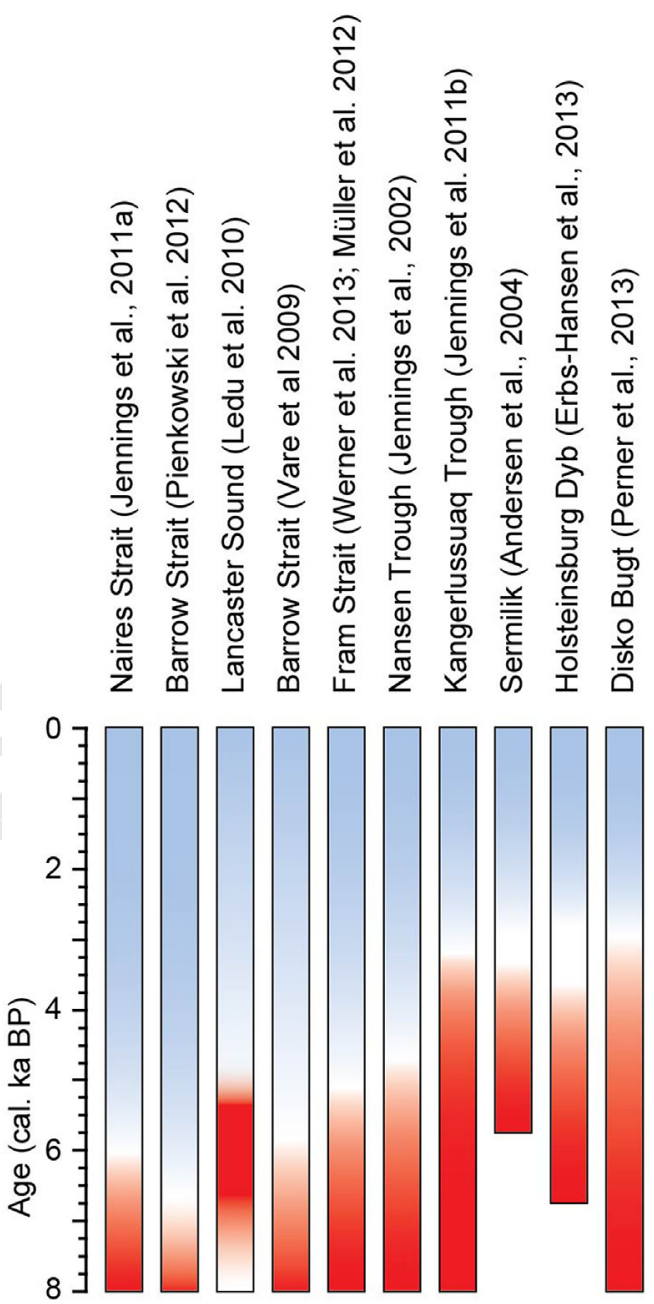

Fig. 8. Selected marine-sediment records showing transition from warm to cool conditions. Arranged (left to right) in order of increasing influence of Irminger Current. Refer to text for site information and sources.

within the late glacial or Holocene. Lake records that begin within the Holocene may not capture the onset of warmth, or necessarily constrain the timing of the warmest conditions of the Holocene, in contrast with ice core records from the GrIS and nearby ice caps (e.g., Agassiz, Devon and Renland) that span the entire Holocene.

\subsubsection{High Canadian Arctic}

High-resolution lacustrine records spanning the entire Holocene are rare in the High Canadian Arctic where the Innuitian Ice Sheet persisted until 8 ka (Fig. 3; O'Cofaigh et al., 2000; Dyke et al., 2002) and its influence on regional climate was strong. Although many small lakes contain sedimentary sequences longer than 8000 years, their sedimentation rates are low (e.g. Smith, 2002) and radiocarbon dating is problematic (e.g. Abbott and Stafford, 1996).

Although many coastal lakes contain varved sediments, their lower portions commonly consist of marine sediments and the sedimentary changes can be difficult to interpret over long time intervals $(>2 \mathrm{ka}$ ) because of changing boundary conditions unrelated to climate. The longest varved sediment sequence yet analyzed from the High Arctic was taken from Lower Murray Lake, Ellesmere Island, which spans the past $5.2 \mathrm{ka}$ (Cook et al., 2009). The mass accumulation rate during the 20th century was positively correlated with instrumental July temperatures. Around $4.9 \mathrm{ka}$, reconstructed temperatures were $3.5{ }^{\circ} \mathrm{C}$ lower than recent 
conditions, possibly because of the proximity of the still receding Innuitian Ice Sheet. Soon after $4.9 \mathrm{ka}$, temperatures increased for the next 4000 years. Temperatures decreased at $\sim 0.65 \mathrm{ka}$ to reach a minimum around $\sim 0.15 \mathrm{ka}$. Since then, temperatures have risen to reach maximum values at the end of the 20th century. Most of the varved sequences display similarities with the Agassiz Ice Cap $\delta^{18} \mathrm{O}$ and/or melt records. A pollen-based temperature reconstruction from Baird Inlet shows cooling in the past 4 ka (Hyvärinen, 1985). Sediments from Lake DV09 in north-central Devon Island shows rapid sedimentation prior to $\sim 6 \mathrm{ka}$, which was interpreted as a relatively warm period (Courtney-Mustaphi and Gajewski, 2013).

\subsubsection{Western Canadian Arctic}

Gajewski et al. (2000) discussed four pollen diagrams from south to north across Banks Island, western Canadian Arctic. Basal ages are $\sim 11.5 \mathrm{ka}$, and pollen data suggest cool conditions from 11.5 to $7.8 \mathrm{ka}$, warm conditions from 7.8 to $2.0 \mathrm{ka}$, and cooling since 2.0 ka (Gajewski et al., 2000). However, this early period of cool conditions contrasts with most climate reconstructions from the western Canadian Arctic. Lake BC01 (Melville Island; Table 1; Fig. 1) has pollen, diatom and sediment data (Fig. 9a) and a reliable chronology that suggests deglaciation of the site by 13 ka (Peros et al., 2010). Pollen assemblages were used to reconstruct July temperature and annual precipitation using the modern analog technique. The data indicate maximum temperatures between 11 and $5 \mathrm{ka}$, and subsequent cooling. Diatoms were essentially absent in sediments older than $5 \mathrm{ka}$, suggesting dissolution during the pollen-inferred warm period (Fig. 8a; Peros et al., 2010).

Lake KR02 (Victoria Island, Table 1; Fig. 1) is among the best dated and most studied lake in the western Canadian Arctic. Pollen was used to reconstruct July temperature and annual precipitation using three different methods, all of which reveal a long-term summer cooling of $\sim 4{ }^{\circ} \mathrm{C}$ through the 10,200-year-long record, with warmest conditions prior to $6-5 \mathrm{ka}$ and cooling beginning at 5 ka (Fig. 9a; Peros and Gajewski, 2008). Chironomid assemblages were also used for a quantitative reconstruction using two different methods (Fortin and Gajewski, 2010) and similarly suggest longterm summer cooling, with highest temperatures between 10.0 and $7.5 \mathrm{ka}$. Although the pollen- and chironomid-inferred temperature trends are similar, they differ in their ranges and absolute temperatures. The diatoms from Lake KR02 are more difficult to interpret (Fig. 9a; Podritzkie and Gajewski, 2007) because no calibration dataset are available for quantitative reconstructions, due in part to lack of analogs in modern assemblages for many fossil assemblages. Recent work suggested that $\mathrm{pH}$, among other limnological variables, is a main factor affecting diatom assemblages in the Arctic (Bouchard et al., 2014; Finkelstein et al., 2014). The zonation of the diatom assemblages from Lake KR02 and scores of the first principal component show transitions at 8.1, 5.8 and $3.6 \mathrm{ka}$. Dissolution zones were identified at 8.5-8.2, 7.6-7.0 and 5.6-5.0 $\mathrm{ka}$. The reason for these is not clear, but Fortin and Gajewski (2010) suggest it is due to lake water $\mathrm{pH}$ changes (Fig. 9a).

Fortin and Gajewski (2009) studied a second lake on Victoria Island, Lake WB02, to generate a chironomid-inferred temperature reconstruction (Fig. 9a), which showed little change during the Holocene. There were a lack of good analogs, and subsequent work (Fortin, 2011; Fortin et al., 2015) with a new training set shows a long-term cooling trend over the past $5 \mathrm{ka}$. Finally, using all available pollen data from the western Canadian Arctic, Gajewski (2015a) reconstructed elevated July temperatures prior to $7 \mathrm{ka}$ and lowest July temperatures between $\sim 4.0$ and $1.0 \mathrm{ka}$ (Fig. 10).

\subsubsection{Central Canadian Arctic}

Pollen concentrations are related to plant production, which is positively associated with temperature (Gajewski, 1995, 2015b).
Long-term cooling since $6 \mathrm{ka}$ is inferred based on pollen concentrations from two lakes on Somerset Island (Fig. 9b; RS36 and RS29; Gajewski, 1995). Pollen data from a lake on Prince of Wales Island (Gajewski and Frappier, 2001) reveal warmest conditions between 7 and $4 \mathrm{ka}$, followed by cooling. Highest values of biogenic silica suggest higher diatom production in Lake PW02 and warmest conditions from 9.5 to $6.5 \mathrm{ka}$ and cooling after 4 ka (Fig. 9b; Finkelstein and Gajewski, 2008). At Lake PW03 (Finkelstein and Gajewski, 2007), there is a hiatus between 10 and 3.5 ka, perhaps due to lake-level changes. A sediment core from Lake JR01 (Table 1; Fig. 1), Boothia Peninsula, was analyzed for diatoms (LeBlanc et al., 2004) and temperature was reconstructed based on pollen assemblage data (Zabenskie and Gajewski, 2007). The record spans the past $7 \mathrm{ka}$, and diatom concentrations are highest prior to $4 \mathrm{ka}$ (Fig. 9b; LeBlanc et al., 2004). Diatom diversity was greater prior to $4.5 \mathrm{ka}$ than at present, and pollen concentrations decreased at 4.2, 3.6 and $2.5 \mathrm{ka}$ interpreted as cooling temperatures. July temperatures have decreased by $\sim 1{ }^{\circ} \mathrm{C}$ since 3.2 ka based on a reconstruction using pollen data and the modern analog technique.

On Southampton Island, a chironomid-based August temperature reconstruction from Caribou Lake (Table 2) suggests temperatures about $2.2^{\circ} \mathrm{C}$ warmer than today from 5.5 to 4.4 ka (Rolland et al., 2008). This was followed by progressive cooling; average temperatures during the last 1000 years were $1.2{ }^{\circ} \mathrm{C}$ lower than before $\sim 4.4 \mathrm{ka}$.

Using the pollen records discussed above, Gajewski (2015a) reconstructed maximum July temperatures prior to $8 \mathrm{ka}$ and lowest July temperatures between 3.7 and $1.0 \mathrm{ka}$ (Fig 10). Although the western Canadian Arctic was warmer than present through most of the Holocene, July temperatures were closer to the present day or slightly cooler in the central Canadian Arctic.

\subsubsection{Eastern Canadian Arctic (Baffin Island)}

On the coastal lowlands of northeastern Baffin Island, lakes were deglaciated prior to the Holocene, permitting reconstruction of conditions through the entire interglacial. Lake CF8 and CF3 (Table 2) record peak Holocene warmth and aquatic productivity $\sim 10$ to $8 \mathrm{ka}$ (Fig. 11). Chironomid-inferred summer temperatures at both sites were several degrees higher than those of the late Holocene from 10 to $8 \mathrm{ka}$ and then gradually declined over several millennia (Briner et al., 2006; Axford et al., 2009, 2011). In these poorly buffered lakes, where climate is hypothesized to exert the primary control on lake water $\mathrm{pH}$ by regulating within-lake dissolved-inorganic-carbon dynamics (Wolfe, 2002), steady declines in diatom-inferred $\mathrm{pH}$ through the Holocene support the temperature inferences from chironomids (Michelutti et al., 2007; Wilson et al., 2012). Pollen from nearby Patricia Bay Lake (Table 2; Kerwin et al., 2004) suggests overall July cooling of $\sim 1{ }^{\circ} \mathrm{C}$ between 7.8 and $3.2 \mathrm{ka}$, which is the duration of that record (Kerwin et al., 2004). The intense summer warmth of the early Holocene on northeast Baffin Island was likely interrupted by at least two centennial-scale cold periods, which are inferred from regional glacier advance and chironomid assemblage shifts at Lake CF8. These may correlate with the Greenland $9.3 \mathrm{ka}$ and 8.2 ka cold events (Axford et al., 2009).

Farther south on Baffin Island, Fréchette et al. (2006, 2008) used pollen to reconstruct July temperature from Fog Lake (Table 2; Fig. 11), which reveal a long-term decline of $\sim 1-2{ }^{\circ} \mathrm{C}$ through the last 8000 years with warmest conditions prior to 5-4 ka. Lowresolution midge-based reconstructions from Fog Lake and nearby Brother of Fog Lake support an early-middle Holocene 1-2 ${ }^{\circ} \mathrm{C}$ warmer than the late Holocene (Francis et al., 2006). A comparable cooling trend of $\sim 2-3{ }^{\circ} \mathrm{C}$ is inferred at Akavaqiak Lake (Table 1; Fig. 1) where highest July temperatures occurred prior to 5 ka (Fréchette and de Vernal, 2009). Kerwin et al. (2004) 

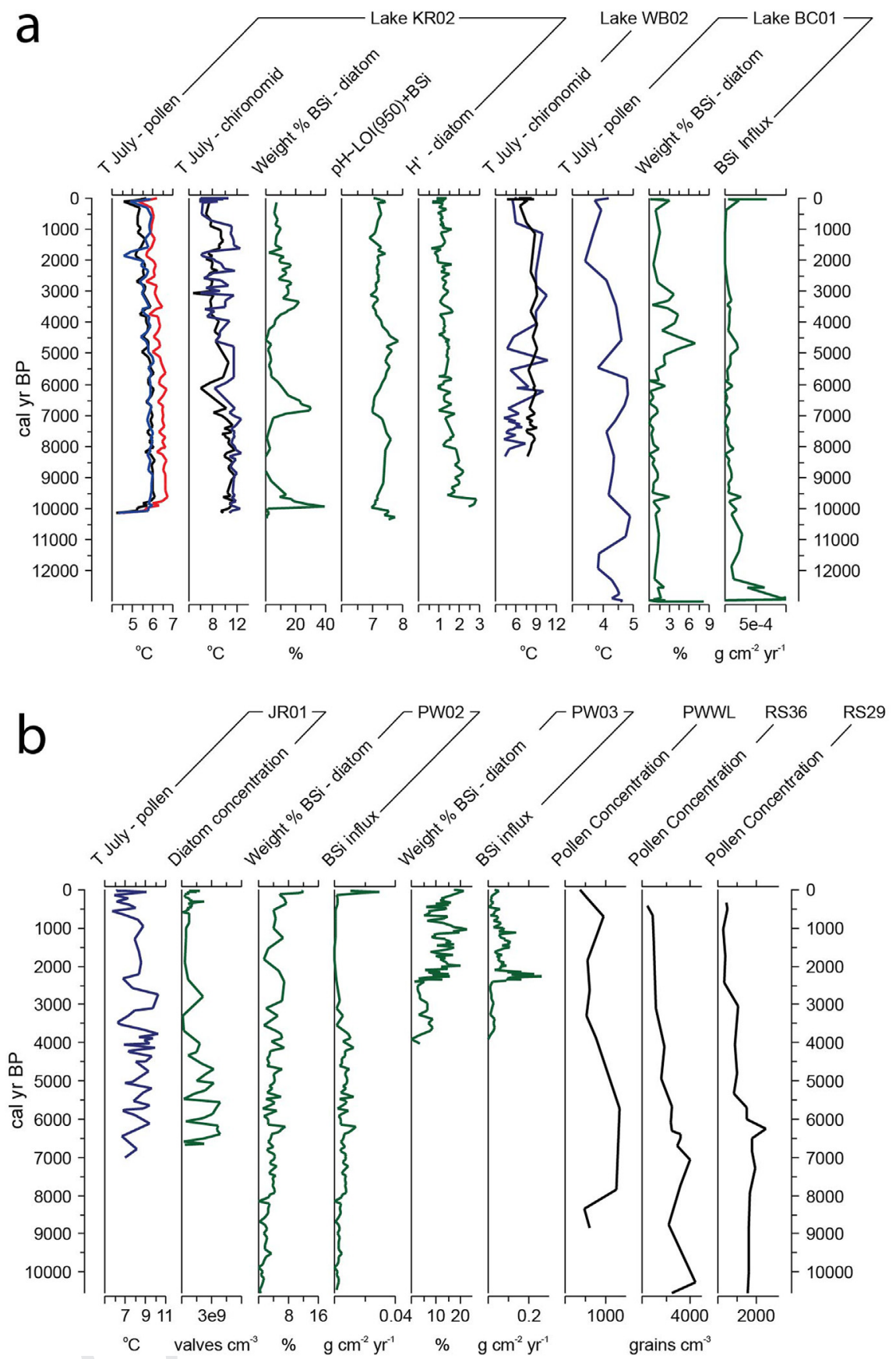

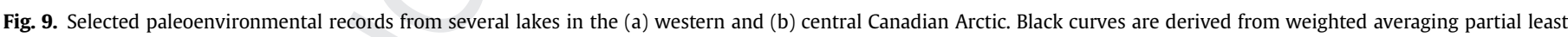

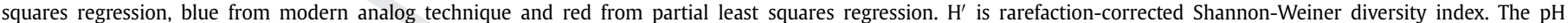

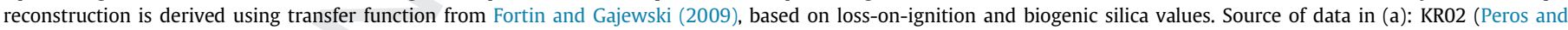

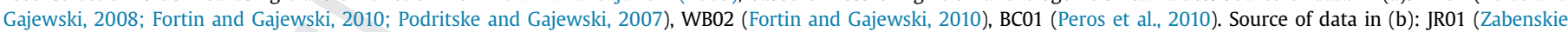

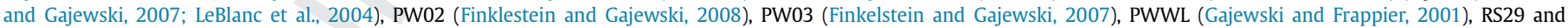
RS36 (Gajewski, 1995). (For interpretation of the references to color in this figure legend, the reader is referred to the web version of this article.)

reconstructed July temperature trends since $8 \mathrm{ka}$ from six pollen records on the southern half of Baffin Island using response surfaces and the modern analog technique. The modern training set used by Kerwin et al. (2004) included 275 surface pollen sites from the eastern Canada boreal forest, forest tundra and tundra. Reconstruction results showed that summers warmer than today $\left(+1\right.$ to $\left.+2{ }^{\circ} \mathrm{C}\right)$ prevailed prior to $4-3 \mathrm{ka}$. Finally, Gajewski (2015a) compiled pollen assemblages from nine sites, which included sites extending earlier than $8.2 \mathrm{ka}$, and inferred maximum July temperatures between $\sim 8.2$ and $5.3 \mathrm{ka}$ and cooler temperatures prior to $8.2 \mathrm{ka}$ (Fig. 10).

\subsubsection{West and south Greenland}

This section summarizes lake records from South, Southwest, West and Northwest Greenland. In the south, there is multi-proxy evidence from multiple sites for overall millennial-scale cooling from the early and middle Holocene to late Holocene. At Qipisarqo Lake (Table 1; Fig. 1), pollen data indicate a sharp increase in July air 


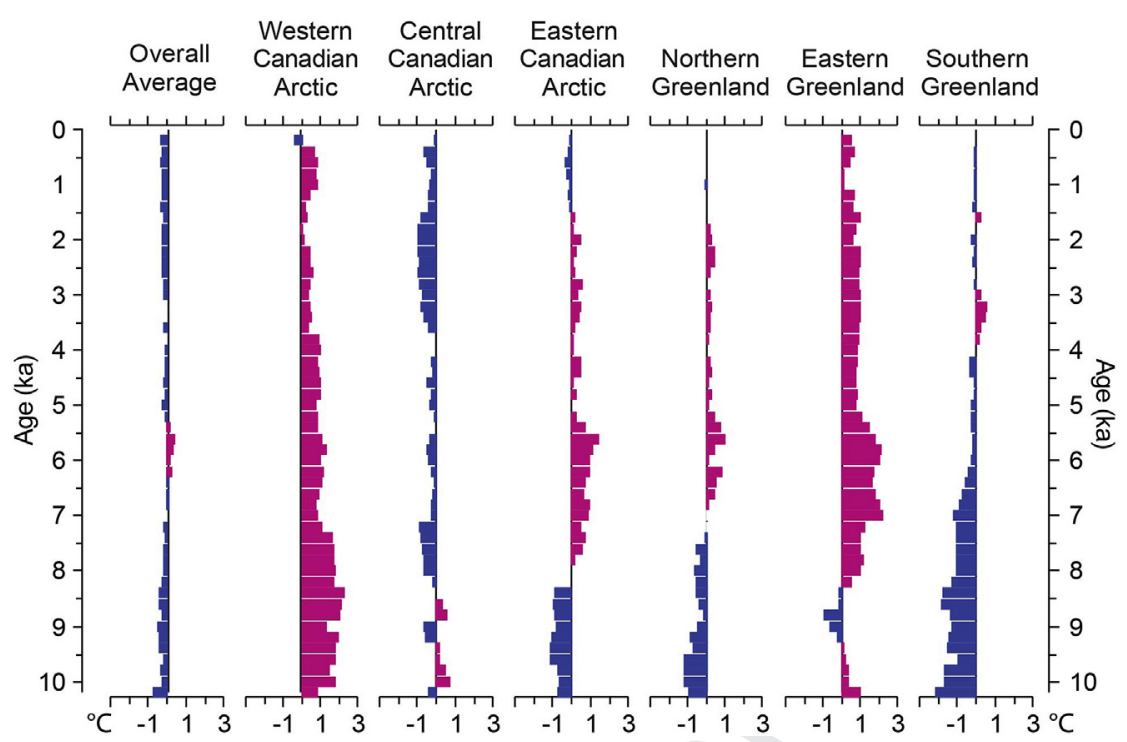

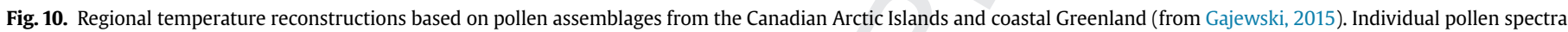

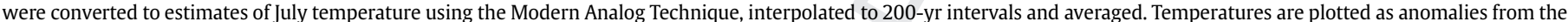
present day. Temperature reconstructions were calculated in R using the MATTOOLS package (Sawada, 2006) and the Whitmore et al. (2005) modern pollen database.

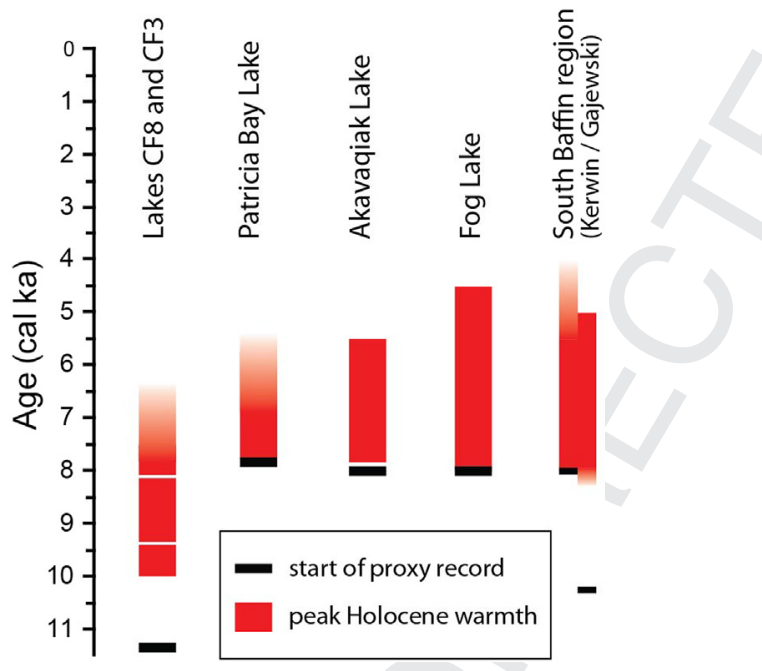

Fig. 11. Timing of the Holocene thermal maximum (red bars) at lakes on Baffin Island, with sites arranged north to south (left to right). Records that do not extend to the early Holocene might not encompass the warmest interval. Refer to text for site information and sources. (For interpretation of the references to color in this figure legend, the reader is referred to the web version of this article.)

temperature of $3-4{ }^{\circ} \mathrm{C}$ at $7.5-7.0 \mathrm{ka}$ and higher temperatures until $5.5-5.0 \mathrm{ka}$. After $5 \mathrm{ka}$, a progressive cooling of $1-2{ }^{\circ} \mathrm{C}$ is inferred (Fig. 12; Fréchette and de Vernal, 2009). Chironomid assemblages and $\delta^{18} \mathrm{O}$ of chironomid head capsules suggest that the period of peak Holocene summer water temperatures began as early as 9.0-8.5 ka, and indicate overall summer cooling from the early Holocene to the last millennium of $\sim 2{ }^{\circ} \mathrm{C}$ (Fig. 12; Wooller et al., 2004). Sediment organic matter and biogenic silica abundance increase from the time of the lake's isolation from the sea at $\sim 9.1 \mathrm{ka}$ through $\sim 6 \mathrm{ka}$, with stable, high abundances from $\sim 6$ to $3 \mathrm{ka}$ and declining abundances after $3 \mathrm{ka}$ (Fig. 12; Kaplan et al., 2002).

Geochemical data from Lake Igaliku (Table 1; Fig. 1) are interpreted as relatively warm conditions at the time of the lake's isolation $\sim 9.5 \mathrm{ka}$, although changes in soil and vegetation cover in the centuries following emergence complicate interpretations for the earliest Holocene (Massa et al., 2012). Geochemistry, pollen and diatoms indicate that relative warmth continued through $\sim 4.8 \mathrm{ka}$, and coldest conditions are inferred after $\sim 3$ ka (Massa et al., 2012). At Lake N14 (Table 1; Figs. 1 and 12), with a basal age of $\sim 14$ ka near the southern tip of Greenland, Andresen et al. (2004) inferred relative warmth and climatic stability from $\sim 8$ to $5 \mathrm{ka}$, and a cooler and more variable climate prior to and thereafter.

The millennial-scale Holocene trends discussed above contrast notably with quantitative temperature inferences from pollen data at eight sites from Southwest and South Greenland (Gajewski, 2015a) - sites previously studied by Fredskild $(1973,1983)$ and Kelly and Funder (1974). Gajewski (2015a) inferred gradual summer warming throughout the early and middle Holocene in this region, with highest July temperatures after $4 \mathrm{ka}$ (Fig. 10). Alnus pollen is a partial driver of this trend (Gajewski, 2015a). Holocene trends in Alnus abundance vary significantly across the region, and the interpretation of Alnus pollen has been debated and remains uncertain (Fredskild, 1973, 1983; Kelly and Funder, 1974; Fréchette and de Vernal, 2009; Massa et al., 2012). However, there are also hints from moraines and marine sediments that Southwest and South Greenland may have experienced hetereogeneous Holocene climate trends, and/or trends contrasting with the surrounding region (Seidenkrantz et al., 2007; Winsor et al., 2014), so agreement among all climate reconstructions in this region is not necessarily to be expected.

The region near Kangerlussuaq $\left(67^{\circ} 0.6^{\prime} \mathrm{N}, 50^{\circ} 42.7^{\prime} \mathrm{W}\right)$, at the head of Søndre Strømfjord in Southwest Greenland, boasts the highest density of paleolimnological studies on Greenland. The relatively wide expanse of ice-free land there and precipitation lee due to Sukkertoppen Iskappe yields a relatively continental-style climate and abundant oligosaline lakes. There are numerous reconstructions of hydroclimate through the middle to late Holocene, including those based upon stable isotopes in lacustrine carbonates, geomorphic reconstructions of lake-level change, and diatom assemblages sensitive to lake water chemistry (e.g., McGowan et al., 2003; Anderson and Leng, 2004; Aebly and Fritz, 2009; Anderson et al., 2012; Perren et al., 2012). Collectively, these records provide strong evidence for greatly reduced effective moisture during the early to middle Holocene (from deglaciation until $\sim 5$ ka or later) relative to the late Holocene (Fig. 12). Additional lacustrine proxies 


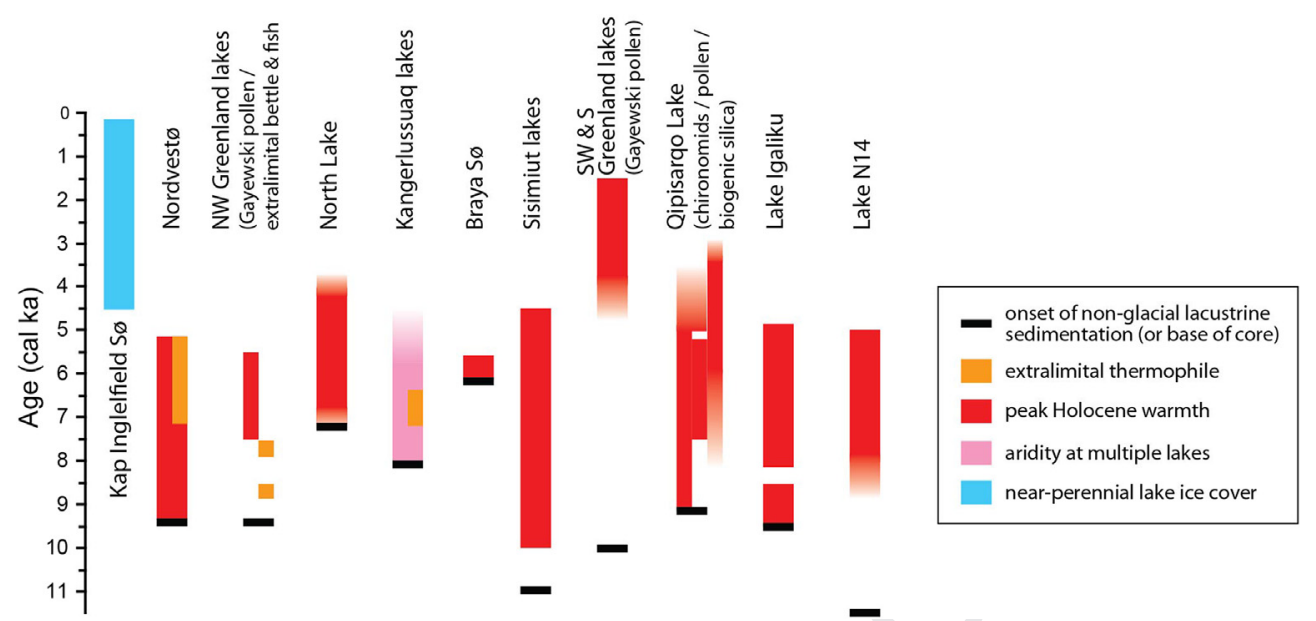

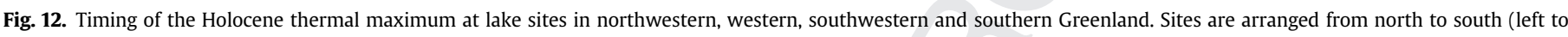
right). Refer to text for site information and sources.

provide independent evidence that warmth accompanied this aridity: A high-resolution alkenone-based quantitative temperature reconstruction that begins $\sim 6.1 \mathrm{ka}$ from Braya Sø (Table 1; Figs. 1 and 11) and nearby Lake E (Table 2) suggests highest temperatures $\sim 6.1-5.6 \mathrm{ka}$, followed by generally cooler but highly variable temperatures through the late Holocene (D'Andrea et al., 2011). The presence of an extralimital, thermophilous ostracode in two other Kangerlussuaq-area lakes from 7.2 to 6.3 ka suggests those centuries may have been the warmest in the region (Bennike, 2000; Bennike et al., 2010). A reconstruction of the North Atlantic Oscillation index through the second half of the Holocene from Lake SS1220 (Table 2) hints at changes in atmospheric circulation that may have accompanied temperature changes in the region (Olsen et al., 2012a). At the outer coast near Susimiut (lakes Sisi12, Sisi14 and Sisi15), the maximum occurrence of statoblasts of the bryozoan Plumatella repens from $\sim 10$ to 4.5 ka probably reflects the transition to cooling $\sim 4.5 \mathrm{ka}$, which is also indicated by geochemical proxies from the lake sediments (Bennike and Wagner, 2012).

Paleolimnological data are notably more sparse north of Kangerlussuaq. One exception is in West Greenland near Ilulissat, where a 7000-year-long summer temperature reconstruction from chironomids at North Lake (Table 1; Fig. 1) is complemented by paleoenvironmental data from four nearby lakes extending back to $9.7 \mathrm{ka}$ (Axford et al., 2013, Fig. 12). These datasets suggest that the warmest summers occurred between 6 and $4 \mathrm{ka}$, with warmerthan-present conditions established by at least $7 \mathrm{ka}$. All five lake records described by Axford et al. (2013) register major transient decreases in organic-matter content between 4.3 and $3.2 \mathrm{ka}$, possibly reflecting a connection between West Greenland's climate and the "4.2 ka event" documented elsewhere (e.g., Booth et al., 2005). After $4 \mathrm{ka}$, chironomid-inferred summer temperatures at North Lake declined by an estimated $\sim 4{ }^{\circ} \mathrm{C}$ into the coldest centuries of the Little Ice Age, followed by a warming of $\sim 2{ }^{\circ} \mathrm{C}$ after the Little Ice Age.

Fredskild (1985) described Holocene trends in pollen assemblages at three lakes in Northwest Greenland (Langesø, Rundesø, and Qeqertat; Table 2), and noted preservation in the early Holocene of two species currently only living farther south. Remains of the beetle Colymbetes dolabratus and the stickleback fish Gasterosteus aculeatus indicate conditions warmer than today and a longer ice-free period $\sim 8.8$ and $\sim 7.5 \mathrm{ka}$, respectively (Fig. 12). In a quantitative analysis of the pollen data from Qeqertat and Langes $\varnothing$, combined with two others from northeastern Greenland and Ellesmere Island, Gajewski (2015a) inferred highest July temperatures between 7.5 and $5.5 \mathrm{ka}$, and an overall decline of $\sim 1.5^{\circ} \mathrm{C}$ between the early and late Holocene (Fig. 10). Bennike et al. (2008a) described peat deposits from Nordvestø (Table 2), an island within the North Water polynya, which may indicate warmer conditions in the early and middle Holocene compared with the late Holocene (Fig. 12). Blake et al. (1992) studied sediment from Kap Inglefield Sø (Table 2) and interpreted the sharp decrease in sedimentation rate and the reduced abundance of algal Scenedesmus as the presence of a nearly permanent ice cover since $4.5 \mathrm{ka}$.

\subsubsection{East Greenland}

East Greenland is here taken in a broad sense, spanning from Northeast to Southeast Greenland. All the Holocene lake records from the region show an early to middle Holocene thermal maximum. In Northeast Greenland, however, the timing of the thermal maximum is not well constrained. The record from Kaffeklubben Sø (Table 2) begins $3.5 \mathrm{ka}$. Diatoms and chrysophysts disappeared at $2.4 \mathrm{ka}$, presumably due to cooling (Perren et al., 2012). The record from Bliss Lake (Table 2) covers most of the Holocene, but the low-elevation lake did not become isolated from the sea until $7.2 \mathrm{ka}$. After isolation, geochemical proxies such as $\delta^{13} \mathrm{C}$ and total organic carbon indicate warmer-than-present conditions until $6.5 \mathrm{ka}$ (Olsen et al., 2012b, Fig. 13). The middle and late Holocene were characterized by colder conditions, except for slightly warmer conditions between 3.3 and $0.9 \mathrm{ka}$.

Pronounced declines in Salix pollen abundance in the sediment form Klaresø (Table 2) and Sommersø (Table 2) are dated to 4.6 and 4.3 ka (Fig. 12; Fredskild, 1969; Funder and Abrahamsen, 1988). Although both ages are uncertain, they are assumed to reflect the end of the thermal maximum. The thermal maximum from Lille Sneha Sø (Table 2) is interpreted to be $\sim 7.7$ to $4.4 \mathrm{ka}$ based on maximum concentrations of chironomids, maximum occurrence of ephippia of the water flea Daphnia pulex, highest organic-matter contents and lowest mineral input (Wagner and Bennike, 2015). The highest temperatures are around $7 \mathrm{ka}$, when macrofossils of Salix arctica achieved maximum concentrations. The transition to cooler conditions began $\sim 5 \mathrm{ka}$, cooling further intensified between 4.1 and $3.5 \mathrm{ka}$, and the coolest conditions are inferred after $\sim 1.1 \mathrm{ka}$ At the southern margin of Skallingen, a record from a small lake near Blåsø confirms the end of the warm part of the Holocene between 5 and $4 \mathrm{ka}$ by a decline in macrofossils, organic carbon and carbonate (Bennike and Weidick, 2001).

Several lakes have been studied farther south, on the island of Store Koldewey. The records from Duck Lake (Table 2) and Hjort 


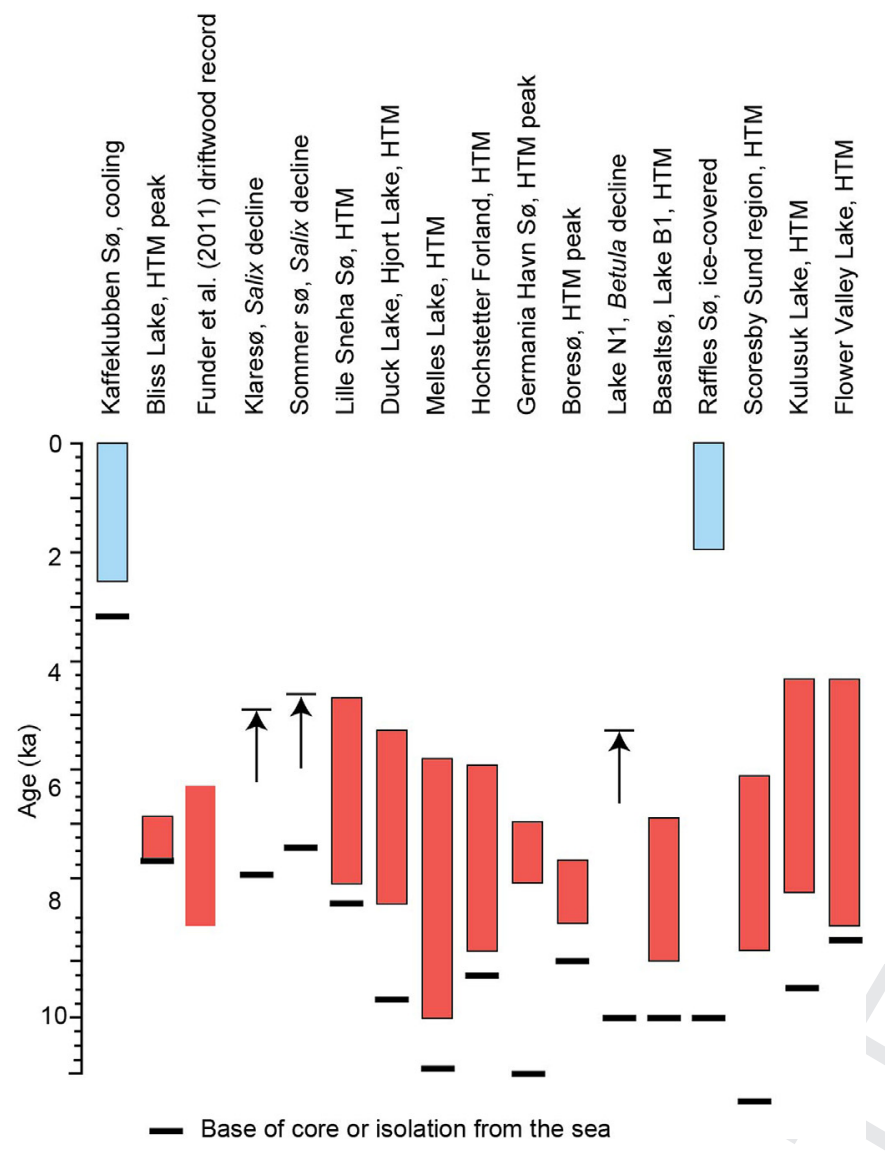

Fig. 13. Timing of the Holocene thermal maximum (red bar), the peak of the Holocene thermal maximum, decline in pollen records or timing of late Holocene cooling (blue bars) in selected records from north to south in eastern Greenland. (For interpretation of the references to color in this figure legend, the reader is referred to the web version of this article.)

Lake (Table 1; Fig. 1 ) indicate the warmest millennia between $\sim 8$ and 4 ka (Fig. 13; Wagner et al., 2008; Klug et al., 2009a; Schmidt et al., 2011) based on aquatic organisms (chironomids). Sediment from Melles Lake (Table 2) on the southern part of the island shows an increase of organic-matter accumulation as early as $10 \mathrm{ka}$ (Klug et al., 2009b), which may mark the earliest onset of Holocene warmth. This early onset of warmth compared with sites farther north is probably due to earlier local deglaciation, and underscores the role of deglaciation in controlling when the thermal maximum can be recorded at a site. The highest concentrations of organic matter and aquatic mosses are in early to mid-Holocene sediments, and the thermal maximum ended here at $\sim 5.5 \mathrm{ka}$. From $\sim 4.5 \mathrm{ka}$, colder climate on the island coincides with increased sea-ice extent on the southeastern Greenland shelf (Jennings et al., 2002).

On Hochstetter Forland, pollen assemblages from Dødis Sø, Peters Bugt Sø, and Ailsa Sø (Table 2) indicate summer temperatures higher than present between 8.8 and $5.6 \mathrm{ka}$ (Björck and Persson, 1981; Björck et al., 1994). Sediment from Germania Havn Sø (Table 2) on Sabine Ø indicates peak warmth at 7.6-6.6 ka (Bennike and Wagner, 2012). Germania Havn Sø shows only small changes in granulometric and geochemical data during the Holocene, which can probably be explained by its location at the outer coast and the buffering effect of the Greenland Sea. However, declining concentrations of Dryas macrofossils and caddis flies in the late Holocene is probably due to decreasing summer temperatures (Bennike and Wagner, 2012). In Boresø (Table 2), peak warmth occurred from 8.3 to $7.3 \mathrm{ka}$, and a further temperature decline is inferred at $5.5 \mathrm{ka}$
(Bennike et al., 2008a, b). The available pollen assemblages from this region indicate the warmest conditions between 8 and $5 \mathrm{ka}$, with temperature below present between 9.2 and $8.5 \mathrm{ka}$, and mild conditions from 5 ka to the present (Gajewski, 2015a, Fig. 10).

Lake N1 (Table 2) from Ymer Ø shows gradually declining Betula pollen percentages from $5 \mathrm{ka}$, which is interpreted as a cooling trend that culminated during the Little Ice Age (Wagner and Melles, 2002). In Basaltsø (Table 2), geochemical, pollen and diatom data indicate that the Holocene thermal maximum spanned from 9 to $6.5 \mathrm{ka}$, somewhat earlier than farther north (Wagner et al., 2000; Cremer et al., 2001). Decreases in several geochemical parameters at $5 \mathrm{ka}$ indicate decreasing temperatures. A similar history is indicated by chironomids from a small nearby Lake B1 (Table 2; Wagner et al., 2005). Raffles Sø experienced more or less ice-free conditions during the summer from the early Holocene until $1.8 \mathrm{ka}$ (Cremer et al., 2001). A broad but not very pronounced maximum in Betula nana pollen between 8.5 and 5 ka may originate from wind transported pollen grains from Liverpool Land and may indicate warmer conditions than today (Wagner and Melles, 2001). In the Scoresby Sund region, the thermal maximum was dated to 8.8 and $5.8 \mathrm{ka}$, with further temperature declines at $\sim 5.2,4.2$ and $3 \mathrm{ka}$ (Funder, 1978).

In the Tasiilaq region, Southeast Greenland, Jakobsen et al. (2008) conclude that maximum warmth occurred from 11.2 to 9.7 $\mathrm{ka}$, which is earlier than any other site from Greenland, including some (e.g., Lake N14) that span this interval; however the interpretations are highly uncertain. Peak occurrences of shrub pollen such as Empetrum, Vaccinium uliginosum and Salix spp. occurred in the middle Holocene, which might represent the Holocene thermal maximum. In the same region, hydrogen isotopes of $n$-alkanes in Flower Valley Lake (Table 1; Fig. 1) on Ammassalik Ø have been used to infer evaporative enrichment of lake water and indicate warmer and/or drier conditions from $\sim 8.4$ to $4.1 \mathrm{ka}$ (Balascio et al., 2013). Finally, Balascio et al. (2015) dated the Holocene thermal maximum to the interval $7.8-4.1 \mathrm{ka}$ based on the sedimentary sequence from Kulusuk Lake. During this time period, no glacier was present in the catchment of the lake, in contrast to the early and late Holocene.

\subsection{Mountain glacier and ice sheet fluctuations in Canada and Greenland}

Mountain glaciers and ice caps in the Canadian Arctic comprise about one third of the total volume of ice stored in mountain glaciers and ice caps globally (Gardner et al., 2011). Along with the GrIS and the independent glaciers that fringe it, Arctic Canada and Greenland collectively play a key role in the Northern Hemisphere's contribution to global sea-level change. Documenting the response of glaciers during periods of past warmth, such as the Holocene thermal maximum, and periods of abrupt climate change, such as the 8.2 ka event, have been important targets for glacial geologists. The task is challenging, however, due to the fact that much of the region has cooled throughout the middle and late Holocene, causing glaciers to expand and obscure evidence of their earlier histories. Nevertheless, scattered records of past glaciation throughout the Canadian Arctic and Greenland do shed light on the history of glacier extent during the Holocene. Because of their large size (hence overall slow response time) and dynamic behavior, we consider ice sheets separately from mountain glaciers; we use mountain glacier records as proxies for Holocene climate change.

\subsubsection{Mountain glacier fluctuations}

Mountain glaciers deposited moraines on Baffin Island during the early Holocene (Miller and Dyke, 1974), although direct ages from these moraines are sparse. Dating of marine deltas formed by 
meltwater from these advances include ages consistent with both the Cockburn Substage ( 9.5-8.5 ka; Andrews and Ives, 1978) and the 8.2 ka event (Miller, 1973). Young et al. (2013a) used ${ }^{10}$ Be dating of moraine boulders on local glacier moraines in northeastern Baffin Island, thought to be equivalent to ice sheet Cockburn moraines, and demonstrated that mountain glaciers deposited moraines at $8.2 \mathrm{ka}$ (Young et al., 2013a). A number of studies using continuous proglacial lake sequences also reveal evidence for glacier expansion during the early Holocene. Glaciers on southern Baffin Island were present in catchments between 10 and $8 \mathrm{ka}$ (Donard Lake; Miller et al., 2005) and at 8.2 ka (Lake Jake, Table 1; Fig. 1; Miller et al., 2005) and on northeastern Baffin Island between 10 and 5 ka (Big Round Lake, Table 1; Fig. 1; Thomas et al., 2010). Thus, mountain glaciers in the eastern Canadian Arctic experienced periods of advance and stability in the early Holocene, superimposed on a general trend of overall mass loss and terminus retreat.

Evidence for widespread glacier advances during the late Holocene is found throughout the Canadian Arctic, but the majority of the chronological studies are from Baffin Island. Mapping of moraine sequences and generalized chronologies derived from lichenometry from the Cumberland Peninsula, Baffin Island (Miller, 1973; Davis, 1985), serves as a foundation for late Holocene glacier histories from Arctic Canada. Glaciers generally approached their late-Holocene-maximum dimensions as early as 3.5 to $2.5 \mathrm{ka}$ (Briner et al., 2009b). Sediment from the proglacial-threshold Donard Lake (above) reveals glacier expansion $\sim 5 \mathrm{ka}$, with a subsequent expanded state, lengthening again $\sim 2$ ka (Miller et al., 2005). Based on populations of radiocarbon ages from ice-killed surface tundra moss, Miller et al. (2013a) found several periods of glacier expansion, beginning about $5 \mathrm{ka}$, and then at various times between 5 and $2 \mathrm{ka}$, with increasing expansion occurring $1.6 \mathrm{ka}$, $\sim 1.1 \mathrm{ka}, \sim 0.7 \mathrm{ka}$ and $\sim 0.5 \mathrm{ka}$ (Anderson et al., 2008; Miller et al., 2012, 2013b; Margreth et al., 2014). Based on increasing mineral matter input at Donard Lake, glacier expansion is interpreted to have begun $\sim 6 \mathrm{ka}$ and intensified at $2.5 \mathrm{ka}$ (following a period nonglacial period from 8 to $6 \mathrm{ka}$; Miller et al., 2005). Big Round Lake sediments reveal renewed glacier activity $\sim 2 \mathrm{ka}$, following a nonglacial period between $\sim 5$ and 2 ka (Thomas et al., 2010). Young et al. (2015) dated moraine sequences in two valleys in northeastern Baffin Island; the ages ranged from 1050 CE through the Little Ice Age, revealing that glaciers were at their late Holocene maximum extents throughout the last millennium, with no pronounced advance at the onset of the Little Ice Age period.

The history of mountain glacier change through the Holocene in Greenland is not well constrained. Although pre-last-millennium local glacier deposits have been described from around Greenland (Kelly, 1980; Kelly and Lowell, 2009), absolute chronologies exist from few locations. For example, in the Disko Bugt region, WestCentral Greenland, local glacier moraines were deposited at or shortly prior to $10 \mathrm{ka}$ (Ingólfsson et al., 1990). Young et al. (2015) dated moraines on Nuussuaq to within the Medieval Warm Period, demonstrating that glaciers were at their late Holocene maximum extents prior to the Little Ice Age period. In North Greenland, local glaciers deposited moraines between 9.6 and 6.3 ka and between 5.5 and 5.0 ka (Möller et al., 2010). In East Greenland, a local ice cap attained its late Holocene maximum position $1.6 \mathrm{ka}$ to today, and during a short-lived episode $\sim 2.6 \mathrm{ka}$ (Levy et al., 2014). Lowell et al. (2013) reconstructed local ice cap history on Liverpool Land, East Greenland, where glaciers were smaller than present between 11.7 and $0.9 \mathrm{ka}$. In Southeast Greenland, Balascio et al. (2015) used a continuous record of glacier length from Kulusuk Lake (Table 2) sediments to conclude that local glaciers were in the catchment until $\sim 9 \mathrm{ka}$, advanced $\sim 8.2 \mathrm{ka}$, were then likely absent until $\sim 4 \mathrm{ka}$ and subsequently experienced net advance until $1.3 \mathrm{ka}$, after which glaciers remained extended until the 20th century. In many places around Greenland the moraine sequence is similar to elsewhere in the Arctic, where glaciers are fronted by a moraine complex that is mostly composed of crests dating to the past millennium, but that also contains crests from earlier in the late Holocene (e.g., Weidick, 1968; Kelly and Lowell, 2009).

\subsubsection{Ice sheet fluctuations}

The Laurentide and Innuitian ice sheets were retreating rapidly yet still sizable at the onset of the Holocene (Fig. 3). Evidence for ice sheet stability and re-advance during the Cockburn Substage was noted long ago (Falconer et al., 1965) and is particularly widespread in fjords and sounds fronting Baffin Bay along eastern Baffin Island (e.g., Andrews and Ives, 1978). The chronology for this period of ice sheet fluctuations is generally not well constrained, but an older phase is dated between 9.8 and 9.4 ka where moraines are graded to marine deltas or where till overlies older marine sediments (Miller and Dyke, 1974). In addition, some moraines formed by ice sheet outlet glaciers and ice-contact marine deltas were deposited coincident with the 8.2 ka event (Briner et al., 2009a; Young et al., 2013a). The fact that multiple moraines were deposited between 10 and $8 \mathrm{ka}$ implies that at least some sectors of the Laurentide Ice Sheet experienced positive mass balance sufficient to result in terminus advances during the early Holocene. This interval may have been wetter than previously and subsequently, and also may have been interrupted by intervals of cool summers (Young et al., 2013a).

The history of the GrIS during the Holocene is based on numerous studies; here we provide a succinct summary. Generally, the GrIS was retreating in the early Holocene and advanced in the late Holocene, but the spatial patterns and precise timing ice margin fluctuations provide important information. Like the Laurentide Ice Sheet, the GrIS deposited moraines throughout the Holocene, and hence was at least periodically in balance with climate. Thus, the retreat of the GrIS through the early and middle Holocene (up until at least $6.8 \mathrm{ka}$, when it retreated to somewhere behind its present margin) was due to an overall warming climate through the early and middle Holocene, and was not a lagged response of the major Late Pleistocene-to-Holocene warming. The most prominent Holocene ice sheet moraines in West Greenland are arguably the multi-crested Fjord Stade moraines. The doublecrested Fjord Stade moraines in the Disko Bugt region (e.g., Weidick, 1968; Long et al., 2006; Weidick and Bennike, 2007) date to 9.3 and $8.2 \mathrm{ka}$ (e.g., Young et al., 2013b), but it remains debated whether or not the entire length of the Fjord Stade moraines date to these discrete intervals.

West of the Fjord Stade moraines in the Kangerlussuaq region, the GrIS deposited a moraine $\sim 9.9 \mathrm{ka}$, and deposited moraines at $\sim 7.3$ and $\sim 6.8$ ka to the east of the Fjord Stade moraines (Ten Brink and Weidick, 1974; Levy et al., 2012; Carlson et al., 2014). Prominent early Holocene moraines are also widespread in North Greenland (e.g., Kelly and Bennike, 1992). Off Northeast Greenland, end moraines indicate that the shelf deglaciated during the late glacial and early Holocene (Winkelmann et al., 2010). Nioghalvfjerdsfjorden $\left(79^{\circ} \mathrm{N}\right)$ was deglaciated between 9.7 and $7.7 \mathrm{ka}$ and became covered by a $\sim 65-\mathrm{km}$-long and 20 -km-wide floating outlet glacier after $4.5 \mathrm{ka}$ (Bennike and Weidick, 2001). The Storstrømmen glacier to the south was smaller than present from 6 to $1 \mathrm{ka}$ (Weidick et al., 1996).

In the Scoresby Sund region, East Greenland, the GrIS deposited moraines during the Milne Land stage (Funder, 1978). The moraines recently have been re-visited and dated precisely, and the inner Milne Land stage moraines are Holocene in age, dating between $\sim 11.0$ and $\sim 10.5$ ka (Hall et al., 2008; Kelly et al., 2008). Following 
the Milne Land stage, the eastern GrIS retreated to within its current extent, and there is no moraine evidence for subsequent fluctuations in the early or middle Holocene. The other location on Greenland with direct chronology relating to Holocene glaciation is in the south, where the GrIS deposited moraines several kilometers beyond historical moraines during the Narssarssuaq stade, dated to $>1.5 \mathrm{ka}$ (Bennike and Sparrenbom, 2007; Winsor et al., 2014).

The minimum Holocene extent of the GrIS is best constrained by sediment from proglacial-threshold lakes (e.g., Kaplan et al., 2002; Briner et al., 2010; Larsen et al., 2011, 2015), and from chronologies of re-worked bivalve shells in late Holocene moraines (e.g., Weidick et al., 2004; Briner et al., 2014). We update data from Larsen et al. (2015) with additional records more recently published to

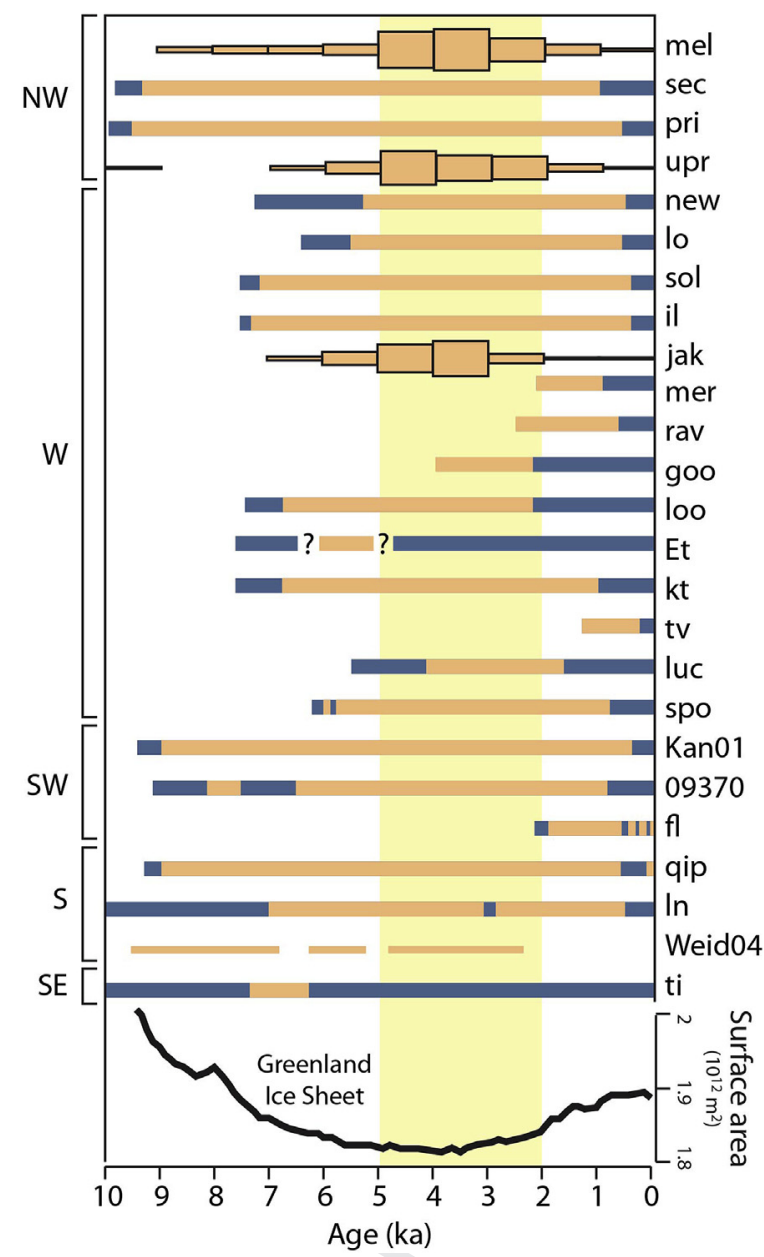

Fig. 14. Constraints on Greenland Ice Sheet size, arranged from north to south, with Southeast at the bottom. Greenland Ice Sheet modeled surface area from Larsen et al. (2015). Using sedimentation in proglacial-threshold lakes, horizontal orange bars indicate times when the GrIS was less extensive than today, and blue horizontal bars indicate times when the GrIS margin was more extensive locally (modified from Larsen et al., 2015). Centered-histograms are the number (box height) of dated bivalves reworked into late Holocene moraines (from Briner et al., 2014). Narrow bars (Weid04) are reworked bivalve ages from Weidick et al. (2004). mel = Mellevlille Bugt; upr = Upernavik Isfjord; jak = Jakobshavn Isfjord (Briner et al., 2014); sec = Secondary Lake; pri = Primary Lake (Briner et al., 2013); new = newspaper Lake (Cronauer et al., this volume); lo = Lake Lo (Håkansson et al., 2014); sol = South Oval Lake; il = Iceboom Lake; mer = Merganser Lake; rav = Raven Lake; goo = Goose Lake; loo = Loon Lake; Et = Eqaluit taserssuat (Briner et al., 2010); kt = Kassuup Tasia; tv = Tininnillik Valley (Kelley et al., 2012); luc = Lake Lucy; spo = Sports Lake (Young and Briner, 2015); Kan01, 09370, fl = Frederikshåb Isblink (Larsen et al., 2015); oip = Qipisarqo Lake (Kaplan et al., 2002); ln = Lower Nordbosø (Larsen et al., 2011); ti = Torqulertivit Imiat (Larsen et al., 2015). (For interpretation of the references to color in this figure legend, the reader is referred to the web version of this article.) constrain the minimum Holocene extent of the GrIS (Fig. 14). Based on available data, the GrIS probably reached its minimum size between $\sim 5$ and $2 \mathrm{ka}$, although certainly there are regional differences in the timing of its minimum configuration and subsequent expansion in the latest Holocene (Fig. 14; Larsen et al., 2015; Young and Briner, 2015).

\section{Synthesis}

\subsection{What was the millennial-scale pattern of temperature change through the Holocene?}

The primary outcome of this synthesis is that most records in Arctic Canada and Greenland display clear evidence for periods of both warmer-than-present and cooler-than-present conditions at the millennial timescale during the Holocene. A large proportion of sites in the Arctic Holocene database (Fig. 4) display a thermal maximum in the early or middle Holocene, and their lowest temperatures in the last millennium, albeit with both spatial and temporal variability. The pattern seen in the heat maps (Fig. 4) using the time series in the Arctic Holocene database is bolstered by the more extensive evidence discussed in this paper. For example, Hjort Lake is the only site included in the Arctic Holocene database (v2) from eastern Greenland, but its record of warmth from 8 to 5 $\mathrm{ka}$ is bolstered by more than a dozen additional records from that region that are not in the database (Fig. 13).

The average and standard deviation of the magnitude of temperature change between the warmest and coldest portions of the Holocene based on reconstructions calibrated to temperature is $3.0 \pm 1.0^{\circ} \mathrm{C}$ (range of $5^{\circ} \mathrm{C}-1.5^{\circ} \mathrm{C}, \mathrm{n}=11$ ). This value is higher than the $1.6 \pm 0.8^{\circ} \mathrm{C}$ that Kaufman et al. (2004) reported, but their value includes sites in the entire Western Hemisphere Arctic, and is the difference between thermal maximum temperatures and "present" temperatures. The Holocene temperature change in Greenland and the Canadian Arctic is higher than the $\sim 1-2{ }^{\circ} \mathrm{C}$ reported from Norway (8-4 ka; Bjune et al., 2005), and the $\leq 1{ }^{\circ} \mathrm{C}$ reported in an updated synthesis of Holocene records from eastern Beringia (Kaufman et al., this volume).

Although many sites experienced a warmer early or middle Holocene and a cooler late Holocene, overall temperature trends through the Holocene varied significantly between sites (Fig. 4), the general pattern previously documented, albeit with fewer records (e.g., Kaufman et al., 2004; Kaplan and Wolfe, 2006). Only a few sites exhibit maximum warmth in the earliest millennia of the Holocene when summer insolation was highest in the region (e.g., Agassiz melt record). Many records lag peak summer insolation and register maximum warmth sometime between $\sim 9$ and 5 ka. However, the lack of earliest Holocene warmth may be related to the presence of ice sheets. Certainly, lakes located within the footprint of early Holocene ice sheet margins (Fig. 3) would not be able to record an early Holocene thermal maximum. Furthermore, ice core sites with $\delta^{18} \mathrm{O}$ and borehole temperature records were higher in elevation (colder) in the early Holocene than they are today. Thus in many areas throughout Arctic Canada and Greenland there is sampling bias against an early Holocene thermal maximum, and a bias toward a middle Holocene thermal maximum. On the other hand, lakes (such as Lake N15, southern Greenland, and Lake BC01, western Canadian Arctic) that lie well beyond early Holocene ice sheet margins (Fig. 1), do not register maximum warmth until the middle Holocene. In any case, despite differences in timing of maximum warmth between sites in this synthesis, almost all sites experienced cooling in the last two millennia.

The heat maps reveal a spatial pattern in the Holocene warm-tocool trend. Many records south of $66^{\circ} \mathrm{N}$, regardless of archive or proxy type, register a later onset of warmth, a milder thermal 

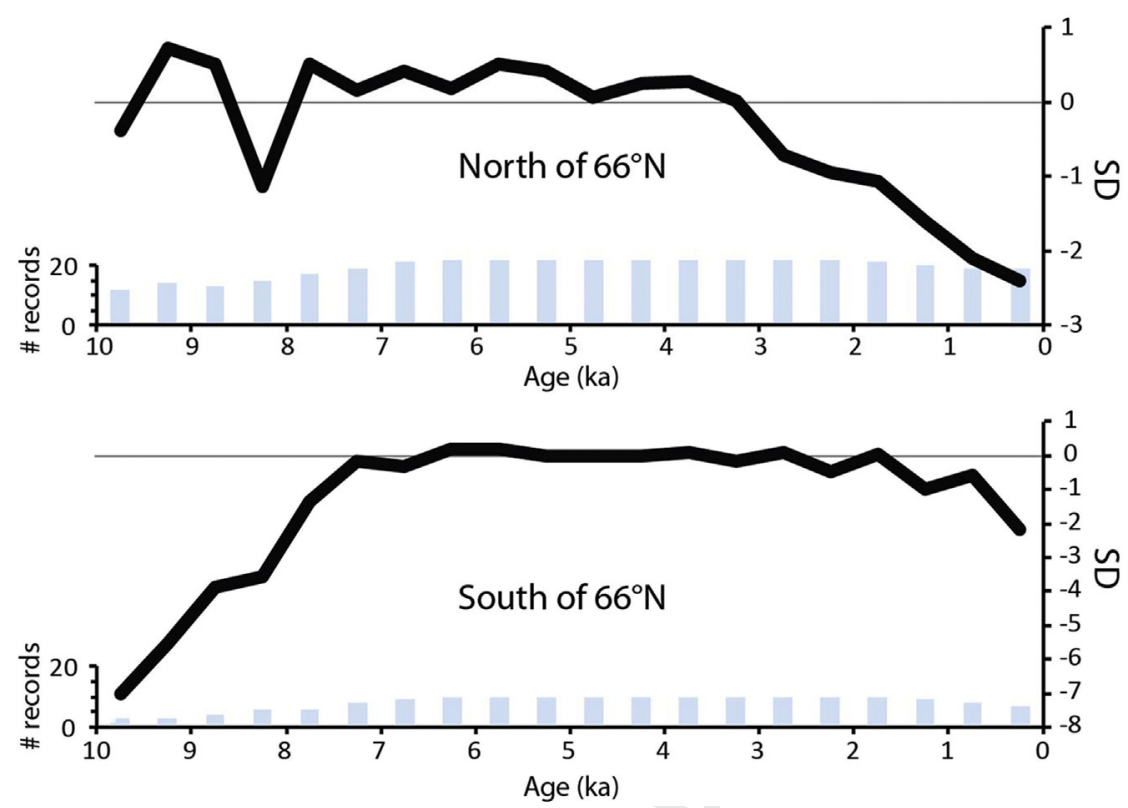

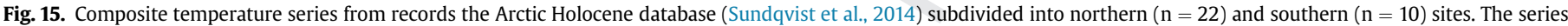

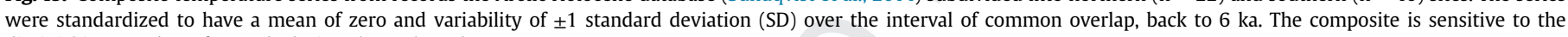
diminishing number of records during the early Holocene.

maximum, and a later onset of cooling compared to records from north of $66^{\circ} \mathrm{N}$ (Fig. 15). This pattern is also prominent in the principal components analysis (Fig. 5), which shows both early warmth and early onset of cooling (PC1) and middle Holocene warmth (PC2). Thus, PC1 and PC2 may be respectively influenced by the spatial pattern illustrated in Fig. 15. Kaufman et al. (2004) also revealed a later initiation of thermal maximum conditions in the south versus the higher latitudes within our focus region. One possible mechanism for the spatiotemporal temperature patterns is that sites more heavily influenced by the size and strength of the North Atlantic subpolar gyre (e.g., South and West Greenland and Labrador) experience peak warmth later in the Holocene than sites less influenced by ocean currents (e.g., North Greenland, western and central Canadian Arctic, mainland Canada) (Rimbu et al., 2003; Thornalley et al., 2013). Gajewski's (2015a) pollen-inferred July temperature pattern from southern Greenland, if reliable (see discussion above), supports the observation of maximum warmth after $4 \mathrm{ka}$ (Fig. 10). If the changes in ice core site elevation were not a factor, there may be a stronger north-to-south gradient in temperature trend, with even more sites north of $66^{\circ} \mathrm{N}$ showing earlier warmth (Figs. 4 and 15). Of course, difference in the timing of warmth registered in all records included in this review might reflect non-climate-related effects or chronological errors.

Marine sediments reveal a different spatial pattern of temperature change than some of the terrestrial records (Fig. 8). A northsouth gradient in the timing of maximum warmth is not clearly evident in the marine records, but this is not surprising given that ocean currents flow meridionally. A notable pattern is earlier cooling $(\sim 7-5 \mathrm{ka})$ in areas less influenced today by North Atlantic currents, particularly the Irminger Current, compared with sites more strongly influenced today by the Irminger Current $(\sim 4-3 \mathrm{ka}$; Fig. 8).

The regional expression of the 8.2 ka event was also assessed Q4 using a detection method described in Morrill et al. (2013). The 8.2 ka event is characterized by proxy records as an abrupt cooling that persisted for 100-150 years, and has been linked to a sudden meltwater pulse into the North Atlantic (e.g., Hoffman et al., 2012). In the Canadian Islands and Greenland portion of the Arctic
Holocene database, 27 records passed a criterion of 100-yearaverage resolution in the interval 6.7-9.7 ka. Of these, 20 records passed an anomaly test for an 8.2 ka event, illustrating the regional importance and coherency of this event.

\subsection{What was the GrIS response to Holocene climate change?}

The overall pattern of GrIS change through the Holocene, retreat during the early and middle Holocene, and advance during the late Holocene, indicates that the GrIS is in balance with climate on millennial timescales. Periods of positive GrIS mass balance in the early Holocene in West Greenland (e.g., during deposition of moraine sequences dating between $\sim 10$ and $\sim 8 \mathrm{ka}$ ) are consistent with cool, pre-thermal maximum conditions in many reconstructions. Subsequent retreat coincided with peak warmth indicated by sites from around Greenland, but our knowledge of the size of the GrIS during the middle Holocene is extremely limited. Two recent reviews of GrIS size during the middle Holocene generally agreed about when the GrIS retracted to its minimum extent. Larsen et al. (2015) suggested that the GrIS experienced its Holocene minimum extent between 6 and $4 \mathrm{ka}$, whereas Young and Briner (2015) suggested minimum ice extent occurred between 4 and $2 \mathrm{ka}$. If thermal maximum conditions throughout most of the region took place during the early or middle Holocene, one might expect that the GrIS would have been its smallest at the end of the warm period, or during the transition to cooler conditions. In fact, most lacustrine and reworked marine bivalve records agree on a period centered $\sim 4 \mathrm{ka}$ as a GrIS minimum (Fig. 13). This is supported by modeling results shown in Larsen et al. (2014) indicating minimum ice volume $\sim 4$ ka (Fig. 13). However, the GrIS spans a large area that almost certainly experienced variable Holocene temperature and precipitation histories (cf. Vinther et al., 2009), and thus it may have experienced different ice margin histories in different ice sheet sectors. Although it is still to early to determine whether the pattern of GrIS change mimics temperature changes discussed in this synthesis, some records shed light on this relation. For example, in southern Greenland where some climate reconstructions show a mild and late thermal maximum, Larsen et al. 
(2011) report minimal retreat of the GrIS during the Holocene. Other records in West Greenland, a region strongly influenced by the Irminger Current's input to the West Greenland Current, also point to minimum ice extent in the middle and late Holocene (Young and Briner, 2015; Cronauer et al., this volume). Overall, the GrIS seems to have been in balance with climate on millennial timescales during the Holocene, suggesting that whole ice sheet response times and dynamic influences on ice margin change operate on sub-millennial timescales or shorter.

\section{Conclusions}

This synthesis of Holocene temperature change in Arctic Canada and Greenland is based on a recently published compilation of proxy records (Sundqvist et al., 2014) together with other evidence, including glacier fluctuations, marine IRD, and time series that did not meet the selection criteria for the Arctic Holocene database. There are too few records at present to make any rigorous analysis of precipitation changes through the Holocene. The spatial pattern of Holocene temperature change documented in this review can serve as a target for climate modeling efforts and a guide for locating data-poor regions and developing new research questions. Such targets for modeling include: (1) the generally earlier period of maximum warmth in the far northern sites and a later period of maximum warmth farther south, (2) a more subtle temperature trend, and perhaps more subdued maximum warmth, at sites around South Greenland and the Labrador Sea, (3) differences in the timing of the warm-to-cool transition related to regions variably influenced by ocean currents, and (4) an overall decrease of $\sim 3.0 \pm 1.0^{\circ} \mathrm{C}$ in the Holocene. One explicit goal of this synthesis is to compare climate reconstructions with the history of the GrIS. In this regard, we find that periods of positive LIS and GrIS mass balance in the early Holocene are consistent with climate reconstructions depicting cool conditions prior to maximum Holocene warmth. Furthermore, it is clear that the minimum GrIS extent was achieved around the time of transition from warm-to-cool conditions recorded at sites around Greenland, as one might expect. However, there are too few studies of GrIS ice margin history to recognize a pattern of change (e.g., north to south) that might coincide with the temperature trends identified in this synthesis.

\section{Acknowledgments}

The authors would like to thank all contributors to the Arctic Holocene Transitions project for helpful discussions over the past several years, and the PAGES International Project Office for facilitating project meetings. Briner acknowledges Charles Porreca for compiling references. Francus thanks François Lapointe for informal discussion and acknowledges financial support by the Natural Sciences and Engineering Research Council of Canada. Gajewski acknowledges financial support by the Natural Sciences and Engineering Research Council of Canada. ARC-1107869 supported McKay's postdoc position during the early stages of this Q5 project.

\section{References}

Abbott, M.B., Stafford Jr., T.W., 1996. Radiocarbon geochemistry of modern and ancient arctic Lake systems, baffin island, Canada. Quat. Res. 45 (3), 300-311. http://dx.doi.org/10.1006/qres.1996.0031.

Adams, J.K., Finkelstein, S.A., 2010. Watershed-scale reconstruction of middle and late Holocene paleoenvironmental changes on Melville Peninsula, Nunavut Canada. Quat. Sci. Rev. 29 (17-18), 2302-2314. http://dx.doi.org/10.1016/ j.quascirev.2010.05.033.

Aebly, F.A., Fritz, S.C., 2009. Palaeohydrology of kangerlussuaq (Søndre strømfjord), west Greenland during the last $~ 8000$ years. Holocene 19 (1), 91-104. http:/ dx.doi.org/10.1177/0959683608096601.

Alley, R.B., Anandakrishnan, S., 1995. Variations in melt-layer frequency in the GISP2 ice core: implications for Holocene summer temperatures in central Greenland. Ann. Glaciol. 21, 64-70.

Anderson, N.J., Brodersen, K.P., Ryves, D.B., McGowan, S., Johansson, L.S., Jeppesen, E. Leng, MJ. 2008. Climate versus In-Lake processes as controls on the development of community structure in a low-arctic Lake (South-West Greenland). Ecosystems 11 (2), 307-324. http://dx.doi.org/10.1007/s10021007-9123-y.

Anderson, N.J., Leng, M.J., 2004. Increased aridity during the early Holocene in West Greenland inferred from stable isotopes in laminated-lake sediments. Quat. Sci. Rev. 23 (7-8), 841-849. http://dx.doi.org/10.1016/j.quascirev.2003.06.013.

Anderson, N.J., Liversidge, A.C., McGowan, S., Jones, M.D., 2012. Lake and catchment response to Holocene environmental change: spatial variability along a climate gradient in southwest Greenland. J. Paleolimnol. 48 (1), 209-222. http:// dx.doi.org/10.1007/s10933-012-9616-3.

Andresen, C.S., Björck, S., Bennike, O., Bond, G., 2004. Holocene climate changes in southern Greenland: evidence from lake sediments. J. Quat. Sci. 19 (8), 783-795. http://dx.doi.org/10.1002/jqs.886.

Andresen, C.S., Hansen, M.J., Seidenkrantz, M.-S., Jennings, A.E., Knudsen, M.F. Nørgaard-Pedersen, N., Larsen, N.K., Kuijpers, A., Pearce, C., 2013. Mid- to lateHolocene oceanographic variability on the Southeast Greenland shelf. Holocene 23 (2), 167-178. http://dx.doi.org/10.1177/0959683612460789.

Andrews, J.T., Ives, J.D., 1978. "Cockburn" nomenclature and the late quaternary history of the eastern Canadian arctic. Arct. Alp. Res. 10 (3), 617-633. http:// dx.doi.org/10.2307/1550683.

Andrews, J.E., Riding, R., Dennis, P.F., 1997. The stable isotope record of environmental and climatic signals in modern terrestrial microbial carbonates from Europe. Palaeogeogr. Palaeoclimatol. Palaeoecol. 129 (1-2), 171-189. http:// dx.doi.org/10.1016/S0031-0182(96)00120-4.

Antoniades, D., Francus, P., Pienitz, R., St-Onge, G., Vincent, W.F., 2011. Holocene dynamics of the Arctic's largest ice shelf. Proc. Natl. Acad. Sci. 108 (47), 18899-18904. http://dx.doi.org/10.1073/pnas.1106378108.

Atkinson, D.E., Gajewski, K., 2002. High-resolution estimation of summer surface air temperature in the Canadian arctic archipelago. J. Clim. 15 (24), 3601-3614. http://dx.doi.org/10.1175/1520-0442(2002)015<3601:HREOSS>2.0.CO;2.

Axford, Y., Briner, J.P., Cooke, C.A., Francis, D.R., Michelutti, N., Miller, G.H., Smol, J.P., Thomas, E.K., Wilson, C.R., Wolfe, A.P., 2009. Recent changes in a remote Arctic lake are unique within the past 200,000 years. Proc. Natl. Acad. Sci. 106 (44), 18443-18446.

Axford, Y, Briner, J.P., Francis, D.R, Miller, G.H., Walker, I.R, Wolfe, A.P. 2011. Chironomids record terrestrial temperature changes throughout Arctic interglacials of the past 200,000 yr. Geol. Soc. Am. Bull. 123 (7-8), 1275-1287.

Axford, Y., Losee, S., Briner, J.P., Francis, D.R., Langdon, P.G., Walker, I.R., 2013. Holocene temperature history at the western Greenland Ice Sheet margin reconstructed from lake sediments. Quat. Sci. Rev. 59 (0), 87-100. http://dx.doi.org/ 10.1016/j.quascirev.2012.10.024.

Balascio, N.L., D'Andrea, W.J., Bradley, R.S., Perren, B.B., 2013. Biogeochemical evidence for hydrologic changes during the Holocene in a lake sediment record from southeast Greenland. Holocene 23 (10), 1428-1439. http://dx.doi.org/ $10.1177 / 0959683613493938$.

Balascio, N.L., D'Andrea, W.J., Bradley, R.S., 2015. Glacier response to North Atlantic climate variability during the Holocene. Clim. Past Discuss. 11, 2009-2036.

Bauch, H.A., Mueller-Lupp, T., Taldenkova, E., Spielhagen, R.F., Kassens, H., Grootes, P.M., Thiede, J., Heinemeier, J., Petryashov, V.V., 2001. Chronology of the holocene transgression at the North Siberian margin. Glob. Planet. Change 31 (1-4), 125-139. http://dx.doi.org/10.1016/S0921-8181(01)00116-3.

Belt, S.T., Vare, L.L., Massé, G., Manners, H.R., Price, J.C., MacLachlan, S.E. Andrews, J.T., Schmidt, S., 2010. Striking similarities in temporal changes to spring sea ice occurrence across the central Canadian Arctic Archipelago over the last 7000 years. Quat. Sci. Rev. 29 (25-26), 3489-3504. http://dx.doi.org/ 10.1016/j.quascirev.2010.06.041.

Bennike, O., 2000. Palaeoecological studies of Holocene lake sediments from west Greenland. Palaeogeogr. Palaeoclimatol. Palaeoecol. 155 (3-4), 285-304. http:// dx.doi.org/10.1016/S0031-0182(99)00121-2.

Bennike, O., 1987. Quaternary geology and biology of the Jørgen Brønlund Fjord area, North Greenland. Medd. Om. Grønl. Geosci. 18, 1-23.

Bennike, O., Anderson, N.J., McGowan, S., 2010. Holocene palaeoecology of southwest Greenland inferred from macrofossils in sediments of an oligosaline lake. J. Paleolimnol. 43 (4), 787-798. http://dx.doi.org/10.1007/s10933-009-9368-x.

Bennike, O., Goodsite, M., Heinemeier, J., 2008a. Palaeoecology of Holocene peat deposits from Nordvestø, north-west Greenland. J. Paleolimnol. 40 (1), 557-565. http://dx.doi.org/10.1007/s10933-007-9181-3.

Bennike, O., Sørensen, M., Fredskild, B., Jacobsen, B.H., Böcher, J., Amsinck, S.L., Jeppesen, E., Andreasen, C., Christiansen, H.H., Humlum, O., 2008b. Late quaternary environmental and cultural changes in the Wollaston forland region, northeast Greenland. In: Hans Meltofte, T.R.C., Elberling, Bo, Forchhammer, Mads C., Rasch, Morten (Eds.), Advances in Ecological Research. Academic Press, pp. 45-79.

Bennike, O., Sparrenbom, C.J., 2007. Dating of the Narssarssuaq stade in southern Greenland. Holocene 17 (2), 279-282. http://dx.doi.org/10.1177/ 0959683607075856.

Bennike, O., Wagner, B., 2012. Deglaciation chronology, sea-level changes and environmental changes from Holocene lake sediments of Germania Havn Sø, Sabine $\emptyset$, northeast Greenland. Quat. Res. 78 (1), 103-109. http://dx.doi.org/ 
10.1016/j.yqres.2012.03.004.

Bennike, O., Wagner, B., 2013. Holocene range of Mytilus edulis in central East Greenland. Polar Rec. 49 (03), 291-296. http://dx.doi.org/10.1017/ S0032247412000277.

Bennike, O., Weidick, A., 2001. Late quaternary history around Nioghalvfjerdsfjorden and Jøkelbugten, North-East Greenland. Boreas 30 (3), 205-227. http://dx.doi.org/10.1111/j.1502-3885.2001.tb01223.x.

Berger, A., Loutre, M.F., 1991. Insolation values for the climate of the last 10 million years. Quat. Sci. Rev. 10 (4), 297-317. http://dx.doi.org/10.1016/0277-3791(91) 90033-Q.

Björck, S., Persson, T., 1981. Late Weichselian and Flandrian biostratigraphy and chronology from hochstetter forland, northeast Greenland. Medd. Om. Grønl. Geosci. 5, 1-19.

Björck, S., Wohlfarth, B., Bennike, O., Hjort, C., Persson, T., 1994. Revision of the early Holocene lake sediment based chronology and event stratigraphy on Hochstetter Forland, NE Greenland. Boreas 23 (4), 513-523. http://dx.doi.org/ 10.1111/j.1502-3885.1994.tb00619.x.

Blake, W.J., Boucherle, M.M., Fredskild, B., Janssens, J.A., Smol, J.P., 1992. The geomorphological setting, glacial history and Holocene development of "Kap Inglefield Sø", Inglefield Land, North-West Greenland. Meddelelser Om. Grønl. Geosci. (27), 1-42

Booth, R.K., Jackson, S.T., Forman, S.L., Kutzbach, J.E., Bettis, E.A., Kreigs, J., Wright, D.K., 2005. A severe centennial-scale drought in midcontinental North America 4200 years ago and apparent global linkages. Holocene 15 (3), 321-328. http://dx.doi.org/10.1191/0959683605hl825ft.

Bouchard, F., Francus, P., Pienitz, R., Laurion, I., Feyte, S., 2014. Subarctic Thermokarst Ponds: Investigating recent Landscape evolution and sediment dynamics in Thawed Permafrost of northern Québec (Canada). Arct. Antarct. Alp. Res. 46 (1), 251-271. http://dx.doi.org/10.1657/1938-4246-46.1.251.

Bradley, R.S., 1990. Holocene paleoclimatology of the Queen Elizabeth islands, Canadian high arctic. Quat. Sci. Rev. 9 (4), 365-384. http://dx.doi.org/10.1016/ 0277-3791(90)90028-9.

Briner, J.P., Bini, A.C., Anderson, R.S., 2009a. Rapid early Holocene retreat of a Laurentide outlet glacier through an Arctic fjord. Nat. Geosci. 2 (7), 496-499. http://dx.doi.org/10.1038/ngeo556.

Briner, J.P., Davis, P.T., Miller, G.H., 2009b. Latest pleistocene and holocene glaciation of baffin island, arctic Canada: key patterns and chronologies. Quat. Sci. Rev. 28 (21-22), 2075-2087. http://dx.doi.org/10.1016/j.quascirev.2008.09.017.

Briner, J.P., Håkansson, L., Bennike, O., 2013. The deglaciation and neoglaciation of Upernavik Isstrøm, Greenland. Quat. Res. 80 (3), 459-467. http://dx.doi.org/ 10.1016/j.yqres.2013.09.008.

Briner, J.P., Kaufman, D.S., Bennike, O., Kosnik, M.A., 2014. Amino acid ratios in reworked marine bivalve shells constrain Greenland Ice Sheet history during the Holocene. Geology 42 (1), 75-78. http://dx.doi.org/10.1130/G34843.1.

Briner, J.P., Michelutti, N., Francis, D.R., Miller, G.H., Axford, Y., Wooller, M.J., Wolfe, A.P., 2006. A multi-proxy lacustrine record of Holocene climate change on northeastern Baffin Island, Arctic Canada. Quat. Res. 65 (3), 431-442. http:// dx.doi.org/10.1016/j.yqres.2005.10.005.

Briner, J.P., Stewart, H.A.M., Young, N.E., Philipps, W., Losee, S., 2010. Using proglacial-threshold lakes to constrain fluctuations of the Jakobshavn Isbrae ice margin, western Greenland, during the Holocene. Quat. Sci. Rev. 29 (27), 3861-3874. http://dx.doi.org/10.1016/j.quascirev.2010.09.005.

Carlson, A.E., Winsor, K., Ullman, D.J., Brook, E.J., Rood, D.H., Axford, Y., LeGrande, A.N., Anslow, F.S., Sinclair, G., 2014. Earliest Holocene south Greenland ice sheet retreat within its late Holocene extent. Geophys. Res. Lett. 41 (15) http://dx.doi.org/10.1002/2014GL060800, 2014GL060800.

Cook, T.L., Bradley, R.S., Stoner, J.S., Francus, P., 2009. Five thousand years of sediment transfer in a high arctic watershed recorded in annually laminated sediments from Lower Murray Lake, Ellesmere Island, Nunavut, Canada. J. Paleolimnol. 41 (1), 77-94. http://dx.doi.org/10.1007/s10933-008-9252-0.

Courtney Mustaphi, C.J., Gajewski, K., 2013. Holocene sediments from a coastal lake on northern Devon Island, Nunavut, Canada. Can. J. Earth Sci. 50 (5), 564-575. http://dx.doi.org/10.1139/cjes-2012-0143.

Cremer, H., Wagner, B., Melles, M., Hubberten, H.-W., 2001. The postglacial environmental development of Raffles Sø, East Greenland: inferences from a 10,000 year diatom record. J. Paleolimnol. 26 (1), 67-87. http://dx.doi.org/10.1023/A: 1011179321529.

Cronauer, S.L., Briner, J.P., Kelley, S.E., Zimmerman, S.R.H., Morlighem, M., 2016. 10Be dating reveals early-middle Holocene age of the Drygalski Moraines in central West Greenland. Quat. Sci. Rev. (in press).

Cuffey, K.M., Clow, G.D., 1997. Temperature, accumulation, and ice sheet elevation in central Greenland through the last deglacial transition. J. Geophys. Res. Oceans (1978-2012) 102 (C12), 26383-26396.

D'Andrea, W.J., Huang, Y., Fritz, S.C., Anderson, N.J., 2011. Abrupt Holocene climate change as an important factor for human migration in West Greenland. Proc. Natl. Acad. Sci. 108 (24), 9765-9769. http://dx.doi.org/10.1073/ pnas.1101708108.

Dahl-Jensen, D., Mosegaard, K., Gundestrup, N., Clow, G.D., Johnsen, S.J., Hansen, A.W., Balling, N., 1998. Past temperatures Directly from the Greenland ice sheet. Science 282 (5387), 268-271. http://dx.doi.org/10.1126/ science.282.5387.268.

Davis, P.T., 1985. Neoglacial moraines on baffin island. Quat. Environ. East. Can. Arct. Baffin Bay West. Greenl. Allen Unwin, Boston 682-718.

de Vernal, A., Rochon, A., Fréchette, B., Henry, M., Radi, T., Solignac, S., 2013. Reconstructing past sea ice cover of the Northern Hemisphere from dinocyst assemblages: status of the approach. Quat. Sci. Rev. 79, 122-134. http:/ dx.doi.org/10.1016/j.quascirev.2013.06.022.

Dyke, A.S., Andrews, J.T., Clark, P.U., England, J.H., Miller, G.H., Shaw, J., Veillette, J.J., 2002. The laurentide and innuitian ice sheets during the last glacial maximum Quat. Sci. Rev. 21 (1-3), 9-31. http://dx.doi.org/10.1016/S0277-3791(01)00095

Dyke, A.S., Dale, J.E., McNeely, R.N., 1996. Marine molluscs as indicators of environmental change in glaciated North america and Greenland during the last 18 000 Years. Géogr. physique Quaternaire 50 (2), 125,. http://dx.doi.org/10.7202/ 033087ar:

Dyke, A.S., Moore, A., Robertson, L., 2003. Deglaciation of North america. Geol. Surv. Can. Open File 1574.

Edlund, S.A., Alt, B.T., 1989. Regional congruence of vegetation and summer climate patterns in the Queen Elizabeth islands, northwest territories, Canada. Arctic 42 (1), 3-23.

England, J.H., Lakeman, T.R., Lemmen, D.S., Bednarski, J.M., Stewart, T.G., Evans, D.J.A., 2008. A millennial-scale record of Arctic Ocean sea ice variability and the demise of the Ellesmere Island ice shelves. Geophys. Res. Lett. 35 (19), L19502. http://dx.doi.org/10.1029/2008GL034470.

Erbs-Hansen, D.R., Knudsen, K.L., Olsen, J., Lykke-Andersen, H., Underbjerg, J.A. Sha, L., 2013. Paleoceanographical development off Sisimiut, West Greenland, during the mid- and late Holocene: a multiproxy study. Mar. Micropaleontol 102, 79-97. http://dx.doi.org/10.1016/j.marmicro.2013.06.003.

Falconer, G., Andrews, J.T., Ives, J.D., 1965. Late-Wisconsin end moraines in northern Canada. Science 147 (3658), 608-610. http://dx.doi.org/10.1126 science.147.3658.608

Fallu, M.-A., Pienitz, R., Walker, I.R., Lavoie, M., 2005. Paleolimnology of a shrubtundra lake and response of aquatic and terrestrial indicators to climatic change in arctic Québec, Canada. Palaeogeogr. Palaeoclimatol. Palaeoecol. 215 (3-4), 183-203. http://dx.doi.org/10.1016/j.palaeo.2004.07.006.

Finkelstein, S.A., Bunbury, J., Gajewski, K., Wolfe, A.P., Adams, J.K., Devlin, J.E., 2014 Evaluating diatom-derived Holocene $\mathrm{pH}$ reconstructions for Arctic lakes using an expanded 171-lake training set. J. Quat. Sci. 29 (3), 249-260. http: dx.doi.org/10.1002/jgs.2697.

Finkelstein, S.A., Gajewski, K., 2007. A palaeolimnological record of diatomcommunity dynamics and late-Holocene climatic changes from Prescott Island, Nunavut, central Canadian Arctic. Holocene 17 (6), 803-812. http:/ dx.doi.org/10.1177/0959683607080521.

Finkelstein, S.A., Gajewski, K., 2008. Responses of Fragilarioid-dominated diatom assemblages in a small Arctic lake to Holocene climatic changes, Russell Island Nunavut, Canada. J. Paleolimnol. 40 (4), 1079-1095. http://dx.doi.org/10.1007/ 10933-008-9215-5.

Fisher, D.A., Koerner, R.M., Kuivinen, K., Clausen, H.B., Johnsen, S.J., Steffensen, J.-P., Gundestrup, N., Hammer, C.U., 1996. Inter-comparison of ice core $\delta(180)$ and precipitation records from sites in Canada and Greenland over the last 3500 years and over the last few centuries in detail using EOF techniques. In: Jones, P.D., Bradley, R.S., Jouzel, J. (Eds.), Climatic Variations and Forcing Mechanisms of the Last 2000 Years. Springer Berlin Heidelberg, pp. 297-328.

Fisher, D., Zheng, J., Burgess, D., Zdanowicz, C., Kinnard, C., Sharp, M., Bourgeois, J. 2012. Recent melt rates of Canadian arctic ice caps are the highest in fou millennia. Glob. Planet. Change 84-85, 3-7. http://dx.doi.org/10.1016 j.gloplacha.2011.06.005.

Fortin, M.-C., 2011. Post-glacial Chironomidae Population Responses to Climatedriven Variations in Lake Aquatic Production in the Canadian Arctic Archipelago [PhD Thesis]. Ottawa-Carleton Institute of Biology, p. 302

Fortin, M.-C., Gajewski, K., 2009. Holocene climate change and its effect on lake ecosystem production on Northern Victoria Island, Canadian Arctic J. Paleolimnol. 43 (2), 219-234. http://dx.doi.org/10.1007/s10933-009-9326-7.

Fortin, M.-C., Gajewski, K., 2010. Postglacial environmental history of western Victoria Island, Canadian Arctic. Quat. Sci. Rev. 29 (17-18), 2099-2110. http:// dx.doi.org/10.1016/j.quascirev.2010.05.004.

Fortin, M.-C., Medeiros, A.S., Gajewski, K., Barley, E.M., Larocque-Tobler, I., Porinchu, D.F., Wilson, S.E., 2015. Chironomid-environment relations in northern North America. J. Paleolimnol. 54, 223-237. http://dx.doi.org/10.1007/ 10933-015-9848-0.

Francis, D.R., Wolfe, A.P., Walker, I.R., Miller, G.H., 2006. Interglacial and Holocene temperature reconstructions based on midge remains in sediments of two lakes from Baffin Island, Nunavut, Arctic Canada. Palaeogeogr. Palaeoclimatol. Palaeoecol. 236 (1-2), 107-124. http://dx.doi.org/10.1016/j.palaeo.2006.01.005.

Fréchette, B., de Vernal, A., 2009. Relationship between Holocene climate variations over southern Greenland and eastern Baffin Island and synoptic circulation pattern. Clim Past. 5 (3), 347-359. http://dx doi.org/10.5194/cp-5-347-2009.

Fréchette, B., de Vernal, A., Richard, P.J.H., 2008. Holocene and last interglacial cloudiness in eastern baffin island, arctic Canada. Can. J. Earth Sci. 45 (11) 1221-1234.

Fréchette, B., Wolfe, A.P., Miller, G.H., Richard, P.J.H., de Vernal, A., 2006. Vegetation and climate of the last interglacial on baffin island, arctic Canada. Palaeogeogr. Palaeoclimatol. Palaeoecol. 236 (1-2), 91-106. http://dx.doi.org/10.1016 palaeo.2005.11.034.

Fredskild, B., 1969. A postglacial standard pollen diagram from Peary Land, North Greenland. Pollen spores 11, 573-583.

Fredskild, B., 1985. Holocene pollen records from west Greenland: quaternary environments: eastern Canadian arctic, baffin Bay and western Greenland. In Andrews, J.T. (Ed.), Allen and Unwin, pp. 643-681. Boston.

Fredskild, B., 1973. Studies in the vegetational history of Greenland. 
Palaeobotaqnical Investigations Some Holocene Lake Bog Deposits with 24 Tables: Reitzel.

Fredskild, B., 1983. The Holocene vegetational development of the Godthåbsfjord area, West Greenland. Medd. Om. Grønl. Geosci. 10, 1-28.

Funder, S.V., 1978. Holocene stratigraphy and vegetation history in the Scoresby Sund area, East Greenland. Bull. Grønl. Geol. Unders. 129, 1-66.

Funder, S., Abrahamsen, N., 1988. Palynology in a polar desert, eastern North Greenland. Boreas 17 (2), 195-207. http://dx.doi.org/10.1111/j.1502 3885.1988.tb00546.x.

Funder, S., Goosse, H., Jepsen, H., Kaas, E., Kjær, K.H., Korsgaard, N.J., Larsen, N.K., Linderson, H., Lyså, A., Möller, P., Olsen, J., Willerslev, E., 2011. A 10,000-Year record of arctic ocean sea-ice Variability-View from the Beach. Science 333 (6043), 747-750. http://dx.doi.org/10.1126/science.1202760.

Funder, S., Weidick, A., 1991. Holocene boreal molluscs in Greenland - palaeoceanographic implications. Palaeogeogr. Palaeoclimatol. Palaeoecol. 85 (1-2), 123-135. http://dx.doi.org/10.1016/0031-0182(91)90029-Q.

Gajewski, K., 1995. Modern and holocene pollen assemblages from some small arctic lakes on Somerset island, NWT, Canada. Quat. Res. 44 (2), 228-236. http://dx.doi.org/10.1006/qres.1995.1067.

Gajewski, K., 2015a. Quantitative reconstruction of holocene temperatures across the Canadian arctic and Greenland. Glob. Planet. Change 128, 14-23. http:/ dx.doi.org/10.1016/j.gloplacha.2015.02.003.

Gajewski, K., 2015b. Impact of holocene climate variability on arctic vegetation Glob. Planet. Change 133, 272-287. http://dx.doi.org/10.1016/ j.gloplacha.2015.09.006.

Gajewski, K., Atkinson, D.A., 2003. Climatic change in northern Canada. Environ. Rev. 11 (2), 69-102. http://dx.doi.org/10.1139/a03-006.

Gajewski, K., Frappier, M., 2001. A Holocene lacustrine record of environmental change in northeastern Prince of Wales Island, Nunavut, Canada. Boreas 30 (4), 285-289. http://dx.doi.org/10.1111/j.1502-3885.2001.tb01047.x.

Gajewski, K., Mott, R.J., Ritchie, J.C., Hadden, K., 2000. Holocene vegetation history of Banks island, northwest territories, Canada. Can. J. Bot. 78 (4), 430-436. http://dx.doi.org/10.1139/b00-018.

Gajewski, K., Peros, M., Finkelstein, S., Fortin, M., 2009. Holocene paleoclimate of the Canadian arctic islands: the ACVAST project. Pages Past. Glob. Chang. News 17 (1), 11-13.

Gardner, A.S., Moholdt, G., Cogley, J.G., Wouters, B., Arendt, A.A., Wahr, J., Berthier, E., Hock, R., Pfeffer, W.T., Kaser, G., Ligtenberg, S.R.M., Bolch, T. Sharp, M.J., Hagen, J.O., et al., 2013. A reconciled estimate of glacier contributions to sea level Rise: 2003 to 2009. Science 340 (6134), 852-857. http:/ dx.doi.org/10.1126/science.1234532.

Gardner, A.S., Moholdt, G., Wouters, B., Wolken, G.J., Burgess, D.O., Sharp, M.J., Cogley, J.G., Braun, C., Labine, C., 2011. Sharply increased mass loss from glacier and ice caps in the Canadian Arctic Archipelago. Nature 473 (7347), 357-360. http://dx.doi.org/10.1038/nature10089.

Gkinis, V., Simonsen, S.B., Buchardt, S.L., White, J.W.C., Vinther, B.M., 2014. Water isotope diffusion rates from the NorthGRIP ice core for the last 16,000 years Glaciological and paleoclimatic implications. Earth Planet. Sci. Lett. 405, 132-141. http://dx.doi.org/10.1016/j.epsl.2014.08.022.

Håkansson, L., Briner, J.P., Andresen, C.S., Thomas, E.K., Bennike, O., 2014. Slow retreat of a land based sector of the West Greenland Ice Sheet during the Holocene Thermal Maximum: evidence from threshold lakes at Paakitsoq. Quat Sci. Rev. 98, 74-83. http://dx.doi.org/10.1016/j.quascirev.2014.05.016.

Hall, B., Baroni, C., Denton, G., Kelly, M.A., Lowell, T., 2008. Relative sea-level change Kjove land, scoresby sund, east Greenland: Implications for seasonality in younger dryas time. Quat. Sci. Rev. 27 (25-26), 2283-2291. http://dx.doi.org/ 10.1016/j.quascirev.2008.08.001.

Hjort, C., Funder, S., 1974. The subfossil occurrence of Mytilus edulis L. in central East Greenland. Boreas 3 (1), 23-33. http://dx.doi.org/10.1111/j.15023885.1974.tb00664.x.

Hoffman, J.S., Carlson, A.E., Winsor, K., Klinkhammer, G.P., LeGrande, A.N. Andrews, J.T., Strasser, J.C., 2012. Linking the $8.2 \mathrm{ka}$ event and its freshwater forcing in the Labrador Sea. Geophys. Res. Lett. 39, L18703. http://dx.doi.org/ 10.1029/2012GL053047.

Hyvärinen, H., 1985. Holocene pollen stratigraphy of Baird Inlet, east-centra Ellesmere Island, arctic Canada. Boreas 14 (1), 19-32. http://dx.doi.org/ 10.1111/j.1502-3885.1985.tb00884.x.

Ingólfsson, Ó., Frich, P., Funder, S., Humlum, O., 1990. Paleoclimatic implications of an early holocene glacier advance on disko island, west Greenland. Boreas 19 (4), 297-311. http://dx.doi.org/10.1111/j.1502-3885.1990.tb00133.x.

Jakobsen, B.H., Fredskild, B., Pedersen, J.B.T., 2008. Holocene changes in climate and vegetation in the Ammassalik area, East Greenland, recorded in lake sediments and soil profiles. Dan. J. Geogr. 108 (1), 21-50. http://dx.doi.org/10.1080/ 00167223.2008.10649573.

Jennings, A., Andrews, J., Pearce, C., Wilson, L., Ólfasdótttir, S., 2015. Detrital carbonate peaks on the Labrador shelf, a 13-7 ka template for freshwater forcing from the Hudson Strait outlet of the Laurentide Ice Sheet into the subpolar gyre. Quat. Sci. Rev. 107, 62-80. http://dx.doi.org/10.1016/j.quascirev.2014.10.022.

Jennings, A., Andrews, J., Wilson, L., 2011a. Holocene environmental evolution of the SE Greenland shelf North and south of the Denmark Strait: Irminger and east Greenland current interactions. Quat. Sci. Rev. 30 (7-8), 980-998. http:// dx.doi.org/10.1016/j.quascirev.2011.01.016.

Jennings, A.E., Knudsen, K.L., Hald, M., Hansen, C.V., Andrews, J.T., 2002. A midHolocene shift in Arctic sea-ice variability on the East Greenland Shelf. Holocene 12 (1), 49-58. http://dx.doi.org/10.1191/0959683602hl519rp.
Jennings, A.E., Sheldon, C., Cronin, T.M., Francus, P., Stoner, J., Andrews, J., 2011b. The holocene history of nares strait: transition from glacial Bay to Arctic-Atlantic throughflow. Oceanography 24 (3), 26-41. http://dx.doi.org/10.5670/ oceanog.2011.52.

Jennings, A.E., Walton, M.E., Ó Cofaigh, C., Kilfeather, A., Andrews, J.T., Ortiz, J.D., De Vernal, A, Dowdeswell, J.A., 2014. Paleoenvironments during younger Dryasearly holocene retreat of the Greenland ice sheet from outer disko trough, central west Greenland. J. Quat. Sci. 29 (1), 27-40. http://dx.doi.org/10.1002/ jqs. 2652.

Jensen, A.S., 1905. On the Mollusca of East-Greenland: I. Lamellibranchiata. With and Introduction on Greenland's Fossil Mollusc-fauna from the quaternary time. Meddelelser Om. Grønl. 29, 287-362.

Kaplan, M.R., Wolfe, A.P., 2006. Spatial and temporal variability of Holocene temperature in the North Atlantic region. Quat. Res. 65 (2), 223-231. http:// dx.doi.org/10.1016/j.yqres.2005.08.020.

Kaplan, M.R., Wolfe, A.P., Miller, G.H., 2002. Holocene environmental variability in southern Greenland inferred from Lake sediments. Quat. Res. 58 (2), 149-159. http://dx.doi.org/10.1006/qres.2002.2352.

Kaufman, D.S., Ager, T.A., Anderson, N.J., Anderson, P.M., Andrews, J.T., Bartlein, P.J., Brubaker, L.B., Coats, L.L., Cwynar, L.C., Duvall, M.L., 2004. Holocene thermal maximum in the western Arctic (0-180 W). Quat. Sci. Rev. 23 (5), 529-560. http://dx.doi.org/10.1016/j.quascirev.2003.09.007.

Kaufman, D.S., Schneider, D.P., McKay, N.P., Ammann, C.M., Bradley, R.S., Briffa, K.R. Miller, G.H., Otto-Bliesner, B.L., Overpeck, J.T., Vinther, B.M., Arctic Lakes 2k Project Members, Abbott, M., Axford, Y., Bird, B., et al., 2009. Recent warming Reverses long-term arctic cooling. Science 325 (5945), 1236-1239. http:// dx doiorg/10,1126/science 1173983.

Kelley, S.E., Briner, J.P., Young, N.E., Babonis, G.S., Csatho, B., 2012. Maximum late Holocene extent of the western Greenland Ice Sheet during the late 20th century. Quat. Sci. Rev. 56, 89-98. http://dx.doi.org/10.1016/ j.quascirev.2012.09.016.

Kelly, M., 1980. The status of the Neoglacial in western Greenland. Rapp. Grønl. Geol. Unders. 64, 1-24.

Kelly, M.R., Bennike, O., 1992. The Quaternary geology of central North Greenland. Rapp. Grønl. Geol. Unders 153, 34-34.

Kelly, M., Funder, S.V., 1974. The pollen stratigraphy of late Quaternary lake sediments of South-West Greenland. Rapp. Grønl. Geol. Unders. 64, 1-26.

Kelly, M.A., Lowell, T.V., 2009. Fluctuations of local glaciers in Greenland during latest Pleistocene and Holocene time. Quat. Sci. Rev. 28 (21-22), 2088-2106. http://dx.doi.org/10.1016/j.quascirev.2008.12.008.

Kelly, M.A., Lowell, T.V., Hall, B.L., Schaefer, J.M., Finkel, R.C., Goehring, B.M., Alley, R.B., Denton, G.H., 2008. A 10Be chronology of lateglacial and Holocene mountain glaciation in the Scoresby Sund region, east Greenland: implications for seasonality during lateglacial time. Quat. Sci. Rev. 27 (25-26), 2273-2282. http://dx.doi.org/10.1016/j.quascirev.2008.08.004.

Kerwin, M.W., Overpeck, J.T., Webb, R.S., Anderson, K.H., 2004. Pollen-based summer temperature reconstructions for the eastern Canadian boreal forest, subarctic, and Arctic. Quat. Sci. Rev. 23 (18-19), 1901-1924. http://dx.doi.org/ 10.1016/j.quascirev.2004.03.013.

Klug, M., Bennike, O., Wagner, B., 2009a. Repeated short-term bioproductivity changes in a coastal lake on Store Koldewey, northeast Greenland: an indicator of varying sea-ice coverage? Holocene 19 (4), 653-663. http://dx.doi.org/ $10.1177 / 0959683609104040$.

Klug, M., Schmidt, S., Bennike, O., Heiri, O., Melles, M., Wagner, B., 2009b. Lake sediments from store Koldewey, northeast Greenland, as archive of late pleistocene and holocene climatic and environmental changes. Boreas 38 (1), 59-71. http://dx.doi.org/10.1111/j.1502-3885.2008.00038.x.

Knudsen, K.L., Stabell, B., Seidenkrantz, M.-S., Eiríksson, J., Blake, W., 2008. Deglacial and Holocene conditions in northernmost Baffin Bay: sediments, foraminifera, diatoms and stable isotopes. Boreas 37 (3), 346-376. http://dx.doi.org/10.1111/ j.1502-3885.2008.00035.x.

Kobashi, T., Kawamura, K., Severinghaus, J.P., Barnola, J.M., Nakaegawa, T., Vinther, B.M., Johnsen, S.J., Box, J.E., 2011. High variability of Greenland surface temperature over the past 4000 years estimated from trapped air in an ice core. Geophys. Res. Lett. 38 (21), L21501.

Kobashi, T., Severinghaus, J.P., Brook, E.J., Barnola, J.M., Grachev, A.M., 2007. Precise timing and characterization of abrupt climate change 8200 years ago from air trapped in polar ice. Quat. Sci. Rev. 26 (9-10), 1212-1222. http://dx.doi.org/ 10.1016/j.quascirev.2007.01.009.

Larsen, N.K., Funder, S., Kjær, K.H., Kjeldsen, K.K., Knudsen, M.F., Linge, H., 2014. Rapid early Holocene ice retreat in West Greenland. Quat. Sci. Rev. 92, 310-323. http://dx.doi.org/10.1016/j.quascirev.2013.05.027.

Larsen, N.K., Kjaer, K.H., Olsen, J., Funder, S., Kjeldsen, K.K., Nørgaard-Pedersen, N., 2011. Restricted impact of Holocene climate variations on the southern Greenland Ice Sheet. Quat. Sci. Rev. 30, 3171-3180. http://dx.doi.org/10.1016/ j.quascirev.2011.07.022.

Larsen, N.K., Kjær, K.H., Lecavalier, B., Bjørk, A.A., Colding, S., Huybrechts, P., Jakobsen, K.E., Kjeldsen, K.K., Knudsen, K.-L., Odgaard, B.V., Olsen, J., 2015. The response of the southern Greenland ice sheet to the Holocene thermal maximum. Geology 43 (4), 291-294. http://dx.doi.org/10.1130/G36476.1.

LeBlanc, M., Gajewski, K., Hamilton, P.B., 2004. A diatom-based Holocene palaeoenvironmental record from a mid-arctic lake on Boothia Peninsula, Nunavut, Canada. Holocene 14 (3), 417-425. http://dx.doi.org/10.1191/ 0959683604hl717rp.

Lecavalier, B.S., Milne, G.A., Vinther, B.M., Fisher, D.A., Dyke, A.S., Simpson, M.J.R., 
2013. Revised estimates of Greenland ice sheet thinning histories based on icecore records. Quat. Sci. Rev. 63, 73-82. http://dx.doi.org/10.1016/ j.quascirev.2012.11.030.

Ledu, D., Rochon, A., de Vernal, A., Barletta, F., St-Onge, G., 2010a. Holocene sea ice history and climate variability along the main axis of the Northwest Passage, Canadian Arctic. Paleoceanography 25 (2), PA2213. http://dx.doi.org/10.1029/ 2009 PA001817.

Ledu, D., Rochon, A., de Vernal, A., St-Onge, G., 2010b. Holocene paleoceanography of the northwest passage, Canadian Arctic Archipelago. Quat. Sci. Rev. 29 (25-26), 3468-3488. http://dx.doi.org/10.1016/j.quascirev.2010.06.018.

Ledu, D., Rochon, A., de Vernal, A., St-Onge, G., 2008. Palynological evidence of Holocene climate change in the eastern Arctic: a possible shift in the Arctic oscillation at the millennial time scaleThis article is one of a series of papers published in this Special Issue on the theme Polar Climate Stability Network. Can. J. Earth Sci. 45 (11), 1363-1375. http://dx.doi.org/10.1139/E08-043.

Levac, E., Vernal, A.D., Blake Jr., W., 2001. Sea-surface conditions in northernmost Baffin Bay during the Holocene: palynological evidence. J. Quat. Sci. 16 (no. 4), 353-363. http://dx.doi.org/10.1002/jqs.614.

Levy, L.B., Kelly, M.A., Howley, J.A., Virginia, R.A., 2012. Age of the Ørkendalen moraines, Kangerlussuaq, Greenland: constraints on the extent of the southwestern margin of the Greenland Ice Sheet during the Holocene. Quat. Sci. Rev. 52, 1-5. http://dx.doi.org/10.1016/j.quascirev.2012.07.021.

Levy, L.B., Kelly, M.A., Lowell, T.V., Hall, B.L., Hempel, L.A., Honsaker, W.M., Lusas, A.R., Howley, J.A., Axford, Y.L., 2014. Holocene fluctuations of Bregne ice cap, Scoresby Sund, east Greenland: a proxy for climate along the Greenland Ice Sheet margin. Quat. Sci. Rev. 92, 357-368. http://dx.doi.org/10.1016/ j.quascirev.2013.06.024.

Lloyd, J.M., Kuijpers, A., Long, A., Moros, M., Park, L.A., 2007. Foraminiferal reconstruction of mid- to late-Holocene ocean circulation and climate variability in Disko Bugt, West Greenland. Holocene 17 (8), 1079-1091. http://dx.doi.org/ 10.1177/0959683607082548.

Long, A.J., Roberts, D.H., Dawson, S., 2006. Early holocene history of the west Greenland ice sheet and the GH-8.2 event. Quat. Sci. Rev. 25 (9-10), 904-922. http://dx.doi.org/10.1016/j.quascirev.2005.07.002.

Lowell, T.V., Hall, B.L., Kelly, M.A., Bennike, O., Lusas, A.R., Honsaker, W., Smith, C.A., Levy, L.B., Travis, S., Denton, G.H., 2013. Late Holocene expansion of Istorvet ice cap, Liverpool Land, east Greenland. Quat. Sci. Rev. 63, 128-140. http:// dx.doi.org/10.1016/j.quascirev.2012.11.012.

Margreth, A., Dyke, A.S., Gosse, J.C., Telka, A.M., 2014. Neoglacial ice expansion and late Holocene cold-based ice cap dynamics on Cumberland Peninsula, Baffin Island, Arctic Canada. Quat. Sci. Rev. 91, 242-256. http://dx.doi.org/10.1016/ j.quascirev.2014.02.005.

Massa, C., Perren, B.B., Gauthier, É., Bichet, V., Petit, C., Richard, H., 2012. A multiproxy evaluation of Holocene environmental change from Lake Igaliku, South Greenland. J. Paleolimnol. 48 (1), 241-258. http://dx.doi.org/10.1007/ s10933-012-9594-5.

Masson-Delmotte, V., Jouzel, J., Landais, A., Stievenard, M., Johnsen, S.J., White, J.W.C., Werner, M., Sveinbjornsdottir, A., Fuhrer, K., 2005. GRIP Deuterium excess reveals rapid and orbital-scale changes in Greenland moisture origin. Science 309 (5731), 118-121. http://dx.doi.org/10.1126/science.1108575.

McGowan, S.M., Ryves, D.B., Anderson, N.J., 2003. Holocene records of effective precipitation in West Greenland. Holocene 13 (2), 239-249. http://dx.doi.org/ 10.1191/0959683603hl610rp.

Michelutti, N., Wolfe, A.P., Briner, J.P., Miller, G.H., 2007. Climatically controlled chemical and biological development in Arctic lakes. J. Geophys. Res. Biogeosciences 112 (G3), G03002. http://dx.doi.org/10.1029/2006JG000396.

Miller, G.H., 1973. Late Quaternary glacial and climatic history of northern Cumberland Peninsula, Baffin Island, N.W.T., Canada. Quat. Res. 3 (4), 561-583. http://dx.doi.org/10.1016/0033-5894(73)90031-8.

Miller, G.H., Briner, J.P., Refsnider, K.A., Lehman, S.J., Geirsdóttir, Á., Larsen, D.J., Southon, J.R., 2013a. Substantial agreement on the timing and magnitude of Late Holocene ice cap expansion between East Greenland and the Eastern Canadian Arctic: a commentary on Lowell et al., 2013. Quat. Sci. Rev. 77, 239-245. http://dx.doi.org/10.1016/j.quascirev.2013.04.019.

Miller, G.H., Dyke, A.S., 1974. Proposed extent of late Wisconsin laurentide ice on eastern baffin island. Geology 2 (3), 125-130. http://dx.doi.org/10.1130/00917613(1974)2<125:PEOLWL>2.0.CO;2.

Miller, G.H., Geirsdóttir, Á., Zhong, Y., Larsen, D.J., Otto-Bliesner, B.L., Holland, M.M., Bailey, D.A., Refsnider, K.A., Lehman, S.J., Southon, J.R., Anderson, C., Björnsson, H., Thordarson, T., 2012. Abrupt onset of the Little Ice Age triggered by volcanism and sustained by sea-ice/ocean feedbacks. Geophys. Res. Lett. 39 (2), L02708. http://dx.doi.org/10.1029/2011GL050168.

Miller, G.H., Lehman, S.J., Refsnider, K.A., Southon, J.R., Zhong, Y., 2013b. Unprecedented recent summer warmth in Arctic Canada. Geophys. Res. Lett. 40 (21) http://dx.doi.org/10.1002/2013GL057188, 2013GL057188.

Miller, G.H., Wolfe, A.P., Briner, J.P., Sauer, P.E., Nesje, A., 2005. Holocene glaciation and climate evolution of baffin island, arctic Canada. Quat. Sci. Rev. 24 (14-15), 1703-1721. http://dx.doi.org/10.1016/j.quascirev.2004.06.021.

Möller, P., Larsen, N.K., Kjær, K.H., Funder, S., Schomacker, A., Linge, H., Fabel, D., 2010. Early to middle Holocene valley glaciations on northernmost Greenland Quat. Sci. Rev. 29 (25-26), 3379-3398. http://dx.doi.org/10.1016/ j.quascirev.2010.06.044.

Moros, M., Jensen, K.G., Kuijpers, A., 2006. Mid-to late-Holocene hydrological and climatic variability in Disko Bugt, central West Greenland. Holocene 16 (3), 357-367. http://dx.doi.org/10.1191/0959683606hl933rp.
Morrill, C., LeGrande, A.N., Renssen, H., Bakker, P., Otto-Bliesner, B.L., 2013. Model sensitivity to North Atlantic fresh-water forcing at $8.2 \mathrm{ka}$. Clim. Past 9, 955-968. http://dx.doi.org/10.5194/cp-9-955-2013.

Müller, J., Werner, K., Stein, R., Fahl, K., Moros, M., Jansen, E., 2012. Holocene cooling culminates in sea ice oscillations in Fram Strait. Quat. Sci. Rev. 47,1-14. http:/ dx.doi.org/10.1016/j.quascirev.2012.04.024.

Nathorst, A.G., 1901. Bidrag til nordöstra Grönlands geologi. Geol. Foren. i Stockh. Förhandlingar 23, 275-306.

Nørgaard-Pedersen, N., Mikkelsen, N., 2009. 8000 year marine record of climate variability and fjord dynamics from Southern Greenland. Mar. Geol. 264 (3-4) 177-189. http://dx.doi.org/10.1016/j.margeo.2009.05.004.

Ó Cofaigh, C., England, J., Zreda, M., 2000. Late Wisconsinan glaciation of southern Eureka sound: evidence for extensive innuitian ice in the Canadian high arctic during the last glacial maximum. Quat. Sci. Rev. 19 (13), 1319-1341. http:// dx.doi.org/10.1016/S0277-3791(99)00104-3.

Olsen, J., Anderson, N.J., Knudsen, M.F., 2012a. Variability of the North Atlantic Oscillation over the past 5,200 years. Nat. Geosci. 5 (11), 808-812. http:// dx.doi.org/10.1038/ngeo1589.

Olsen, J., Kjær, K.H., Funder, S., Larsen, N.K., Ludikova, A., 2012b. High-Arctic climate conditions for the last 7000 years inferred from multi-proxy analysis of the Bliss Lake record, North Greenland. J. Quat. Sci. 27 (3), 318-327. http://dx.doi.org/ $10.1002 /$ jqs.1548.

Ouellet-Bernier, M.-M., Vernal, A., de, Hillaire-Marcel, C., Moros, M., 2014. Paleoceanographic changes in the disko bugt area, west Greenland, during. Holocene. http://dx.doi.org/10.1177/0959683614544060, 0959683614544060.

Perner, K., Moros, M., Jennings, A., Lloyd, J.M., Knudsen, K.L., 2012. Holocene palaeoceanographic evolution off West Greenland. Holocene. http://dx.doi.org $10.1177 / 0959683612460785,0959683612460785$.

Peros, M.C., Gajewski, K., 2008. Holocene climate and vegetation change on Victoria Island, western Canadian Arctic. Quat. Sci. Rev. 27 (3-4), 235-249. http:/ dx.doi.org/10.1016/j.quascirev.2007.09.002

Peros, M., Gajewski, K., Paull, T., Ravindra, R., Podritske, B., 2010. Multi-proxy record of postglacial environmental change, south-central Melville Island, Northwest Territories, Canada. Quat. Res. 73 (2), 247-258. http://dx.doi.org/10.1016/ j.yqres.2009.11.010.

Perren, B.B., Wolfe, A.P., Cooke, C.A., Kjær, K.H., Mazzucchi, D., Steig, E.J., 2012 Twentieth-century warming revives the world's northernmost lake. Geology 40 (11), 1003-1006. http://dx.doi.org/10.1130/G33621.1.

Pieńkowski, A.J., England, J.H., Furze, M.F.A., Marret, F., Eynaud, F., Vilks, G. Maclean, B., Blasco, S., Scourse, J.D., 2012. The deglacial to postglacial marine environments of SEBarrow Strait, Canadian Arctic Archipelago. Boreas 41 (2) 141-179. http://dx.doi.org/10.1111/j.1502-3885.2011.00227.x.

Podritske, B., Gajewski, K., 2007. Diatom community response to multiple scales of Holocene climate variability in a small lake on Victoria Island, NWT, Canada. Quat. Sci. Rev. 26 (25-28), 3179-3196. http://dx.doi.org/10.1016/ j.quascirev.2007.06.009.

Renssen, H., Seppä, H., Heiri, O., Roche, D.M., Goosse, H., Fichefet, T., 2009. The spatial and temporal complexity of the Holocene thermal maximum. Nat Geosci. 2 (6), 411-414. http://dx.doi.org/10.1038/ngeo513.

Rimbu, N., Lohmann, G., Kim, J.-H., Arz, H.W., Schneider, R., 2003. Arctic/North Atlantic Oscillation signature in Holocene sea surface temperature trends as obtained from alkenone data. Geophys. Res. Lett. 30 (6), 1280. http://dx.doi.org/ 10.1029/2002GL016570.

Rolland, N., Larocque, I., Francus, P., Pienitz, R., Laperrière, L., 2008. Holocene climate inferred from biological (Diptera: Chironomidae) analyses in a Southampton Island (Nunavut, Canada) lake. Holocene 18 (2), 229-241. http://dx.doi.org/ $10.1177 / 0959683607086761$.

Sawada, M., 2006. An open source implementation of the Modern Analog Technique (MAT) within the R computing environment. Comput. Geosciences 32 (6), 818-833. http://dx.doi.org/10.1016/j.cageo.2005.10.008.

Schmidt, S., Wagner, B., Heiri, O., Klug, M., Bennike, O., Melles, M., 2011. Chironomids as indicators of the Holocene climatic and environmental history of two lakes in Northeast Greenland. Boreas 40 (1), 116-130. http://dx.doi.org/10.1111/ j.1502-3885.2010.00173.x.

Seidenkrantz, M.-S., Aagaard-Sørensen, S., Sulsbrück, H., Kuijpers, A., Jensen, K.G., Kunzendorf, H., 2007. Hydrography and climate of the last 4400 years in a SW Greenland fjord: implications for Labrador Sea palaeoceanography. Holocene 17 (3), 387-401. http://dx.doi.org/10.1177/0959683607075840.

Seidenkrantz, M.-S., Roncaglia, L., Fischel, A., Heilmann-Clausen, C., Kuijpers, A Moros, M., 2008. Variable North Atlantic climate seesaw patterns documented by a late Holocene marine record from Disko Bugt, West Greenland. Mar

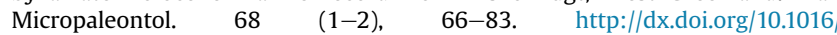
j.marmicro.2008.01.006.

Sha, L., Jiang, H., Seidenkrantz, M.-S., Knudsen, K.L., Olsen, J., Kuijpers, A., Liu, Y., 2014. A diatom-based sea-ice reconstruction for the Vaigat Strait (Disko Bugt West Greenland) over the last 5000 yr. Palaeogeogr. Palaeoclimatol. Palaeoecol. 403, 66-79. http://dx.doi.org/10.1016/j.palaeo.2014.03.028.

Shanahan, T.M., Hughen, K.A., Ampel, L., Sauer, P.E., Fornace, K., 2013. Environmental controls on the $2 \mathrm{H} / 1 \mathrm{H}$ values of terrestrial leaf waxes in the eastern Canadian Arctic. Geochimica Cosmochimica Acta 119, 286-301. http:/ dx.doi.org/10.1016/j.gca.2013.05.032.

Smith, I.R., 2002. Diatom-based Holocene paleoenvironmental records from continental sites on northeastern Ellesmere Island, high Arctic, Canada. J. Paleolimnol. 27 (1), 9-28. http://dx.doi.org/10.1023/A:1013514305420.

Solignac, S., Giraudeau, J., de Vernal, A., 2006. Holocene sea surface conditions in 
the western North Atlantic: spatial and temporal heterogeneities. Paleoceanography 21 (2), PA2004. http://dx.doi.org/10.1029/2005PA001175.

Sundqvist, H.S., Kaufman, D.S., McKay, N.P., Balascio, N.L., Briner, J.P., Cwynar, L.C. Sejrup, H.P., Seppä, H., Subetto, D.A., Andrews, J.T., Axford, Y., Bakke, J., Birks, H.J.B., Brooks, S.J., et al., 2014. Arctic Holocene proxy climate database new approaches to assessing geochronological accuracy and encoding climate variables. Clim. Past. 10 (4), 1605-1631. http://dx.doi.org/10.5194/cp-10-16052014.

Ten Brink, N.W., Weidick, A., 1974. Greenland ice sheet history since the last glaciation. Quat. Res. 4 (4), 429-440. http://dx.doi.org/10.1016/0033-5894(74) 90038-6.

Thomas, E.K., Szymanski, J., Briner, J.P., 2010. Holocene alpine glaciation inferred from lacustrine sediments on northeastern Baffin Island, Arctic Canada. J. Quat. Sci. 25 (2), 146-161. http://dx.doi.org/10.1002/jqs.1286.

Thornalley, D.J.R., Blaschek, M., Davies, F.J., Praetorius, S., Oppo, D.W., McManus, J.F., Hall, I.R., Kleiven, H., Renssen, H., McCave, I.N., 2013. Long-term variations in Iceland-Scotland overflow strength during the Holocene. Clim. Past 9 (5) 2073-2084. http://dx.doi.org/10.5194/cp-9-2073-2013.

Tipping, M.E., Bishop, C.M., 1999. Probabilistic principal component analysis. J. R. Stat. Soc. Ser. B Stat. Methodol. 61 (3), 611-622.

Vare, L.L., Massé, G., Gregory, T.R., Smart, C.W., Belt, S.T., 2009. Sea ice variations in the central Canadian arctic archipelago during the holocene. Quat. Sci. Rev. 28 (13-14), 1354-1366. http://dx.doi.org/10.1016/j.quascirev.2009.01.013.

Vinther, B.M., Buchardt, S.L., Clausen, H.B., Dahl-Jensen, D., Johnsen, S.J., Fisher, D.A., Koerner, R.M., Raynaud, D., Lipenkov, V., Andersen, K.K., Blunier, T. Rasmussen, S.O., Steffensen, J.P., Svensson, A.M., 2009. Holocene thinning of the Greenland ice sheet. Nature 461 (7262), 385-388. http://dx.doi.org/10.1038 nature08355.

Wagner, B., Melles, M., 2001. A Holocene seabird record from Raffles Sø sediments, East Greenland, in response to climatic and oceanic changes. Boreas 30 (3) 228-239. http://dx.doi.org/10.1111/j.1502-3885.2001.tb01224.x.

Wagner, B., Melles, M., 2002. Holocene environmental history of western Ymer Ø, East Greenland, inferred from lake sediments. Quat. Int. 89 (1), 165-176. http:/ dx.doi.org/10.1016/S1040-6182(01)00087-8.

Wagner, B., Bennike, O., 2012. Chronology of the last deglaciation and Holocene environmental changes in the Sisimiut area, SW Greenland based on lacustrine records. Boreas 41, 481-493. http://dx.doi.org/10.1111/j.1502 3885.2011.00245.x

Wagner, B., Bennike, O., 2015. Holocene environmental change in the Skallingen area, eastern North Greenland, based on a lacustrine record. Boreas 44 (1) 45-59. http://dx.doi.org/10.1111/bor12085.

Wagner, B., Melles, M., Hahne, J., Niessen, F., Hubberten, H.-W., 2000. Holocene climate history of Geographical Society Ø, East Greenland - evidence from lake sediments. Palaeogeogr. Palaeoclimatol. Palaeoecol. 160 (1-2), 45-68. http:/ dx.doi.org/10.1016/S0031-0182(00)00046-8.

Wagner, B., Heiri, O., Hoyer, D., 2005. Chironomids as proxies for palaeoenvironmental changes in east Greenland: a holocene record from Geographical society Ø. Z. Dtsch. Ges. für Geowiss. 156 (4), 543-556. http:/ dx.doi.org/10.1127/1860-1804/2005/0156-0543.

Wagner, B., Bennike, O., Bos, J.A.A., Cremer, H., Lotter, A.F., Melles, M., 2008 A multidisciplinary study of holocene sediment records from hjort sø on store Koldewey, northeast Greenland. J. Paleolimnol. 39 (3), 381-398. http:/ dx.doi.org/10.1007/s10933-007-9120-3.

Weidick, A., 1968. Observations on some Holocene glacier fluctuations in West
Greenland. Medd. Om. Grønl. 165 (6), 1-202.

Weidick, A., Andreasen, C., Oerter, H., Reeh, N., 1996. Neoglacial glacier changes around Storstrommen, North-East Greenland. Polarforschung 64 (3), 95-108.

Weidick, A., Bennike, O., 2007. Quaternary glaciation history and glaciology of jakobshavn Isbræ and the disko bugt region, west Greenland: a review. Geol. Surv. Den. Greenl. Bull. 14 (1-78)

Weidick, A., Kelly, M., Bennike, O., 2004. Late Quaternary development of the southern sector of the Greenland Ice Sheet, with particular reference to the Qassimiut lobe. Boreas 33 (4), 284-299. http://dx.doi.org/10.1111/j.15023885.2004.tb01242.x.

Werner, K., Spielhagen, R.F., Bauch, D., Hass, H.C., Kandiano, E., 2013. Atlantic Water advection versus sea-ice advances in the eastern Fram Strait during the last 9 ka: multiproxy evidence for a two-phase Holocene. Paleoceanography 28 (2), 283-295. http://dx.doi.org/10.1002/palo.20028.

Whitmore, J., Gajewski, K., Sawada, M., Williams, J.W., Shuman, B., Bartlein, P.J., Minckley, T., Viau, A.E., Webb III, T., Shafer, S., Anderson, P., Brubaker, L., 2005. Modern pollen data from North America and Greenland for multi-scale paleoenvironmental applications. Quat. Sci. Rev. 24 (16-17), 1828-1848. http:// dx.doi.org/10.1016/j.quascirev.2005.03.005.

Wilson, C.R., Michelutti, N., Cooke, C.A., Briner, J.P., Wolfe, A.P., Smol, J.P., 2012. Arctic lake ontogeny across multiple interglaciations. Quat. Sci. Rev. 31, 112-126. http://dx.doi.org/10.1016/j.quascirev.2011.10.018.

Winkelmann, D., Jokat, W., Jensen, L., Schenke, H.-W., 2010. Submarine end moraines on the continental shelf off NE Greenland - implications for Lateglacial dynamics. Quat. Sci. Rev. 29 (9-10), 1069-1077. http://dx.doi.org/10.1016/ j.quascirev.2010.02.002.

Winsor, K., Carlson, A.E., Rood, D.H., 2014. 10Be dating of the Narsarsuaq moraine in southernmost Greenland: evidence for a late-Holocene ice advance exceeding the Little Ice Age maximum. Quat. Sci. Rev. 98, 135-143. http://dx.doi.org/ 10.1016/j.quascirev.2014.04.026.

Wolfe, A.P., 2002. Climate modulates the acidity of Arctic lakes on millennial time scales. Geology 30 (3), 215-218. http://dx.doi.org/10.1130/0091-7613(2002) 030<0215:CMTAOA $>2.0 . C O ; 2$.

Wooller, M.J., Francis, D., Fogel, M.L., Miller, G.H., Walker, I.R., Wolfe, A.P., 2004 Quantitative paleotemperature estimates from $\delta 180$ of chironomid head capsules preserved in arctic lake sediments. J. Paleolimnol. 31 (3), 267-274. http:// dx.doi.org/10.1023/B: JOPL.0000021944.45561.32.

Young, N.E., Briner, J.P., 2015. Holocene evolution of the western Greenland Ice Sheet: assessing geophysical ice-sheet models with geological reconstructions of ice-margin change. Quat. Sci. Rev. 114, 1-17. http://dx.doi.org/10.1016/ j.quascirev.2015.01.018.

Young, N.E., Briner, J.P., Rood, D.H., Finkel, R.C., 2013a. Glacier extent during the younger dryas and 8.2-ka event on baffin island, arctic Canada. Science 337 (6100), 1330-1333. http://dx.doi.org/10.1126/science.1222759.

Young, N.E., Briner, J.P., Rood, D.H., Finkel, R.C., Corbett, L.B., Bierman, P.R., 2013b. Age of the Fjord Stade moraines in the Disko Bugt region, western Greenland, and the 9.3 and 8.2 ka cooling events. Quat. Sci. Rev. 60 (0), 76-90. http:/| dx.doi.org/10.1016/j.quascirev.2012.09.028.

Young, N.E., Schweinsberg, A., Briner, J.P., Schaefer, J.M., 2015. Glacier maxima in baffin Bay during the medieval warm period coeval with norse settlement. Sci. Adv. 1 (11), e1500806.

Zabenskie, S., Gajewski, K., 2007. Post-Glacial climatic change on Boothia Peninsula, Nunavut, Canada. Quat. Res. 68 (2), 261-270. http://dx.doi.org/10.1016/ j.yqres.2007.04.003. 